\title{
Urinary incontinence and voiding disorders in the elderly : towards acceptable and applicable diagnostic evaluation
}

Citation for published version (APA):

Remmers, A. (1994). Urinary incontinence and voiding disorders in the elderly : towards acceptable and applicable diagnostic evaluation. [Doctoral Thesis, Maastricht University]. Datawyse / Universitaire Pers Maastricht. https://doi.org/10.26481/dis.19941209ar

Document status and date:

Published: 01/01/1994

DOI:

10.26481/dis.19941209ar

Document Version:

Publisher's PDF, also known as Version of record

Please check the document version of this publication:

- A submitted manuscript is the version of the article upon submission and before peer-review. There can be important differences between the submitted version and the official published version of record.

People interested in the research are advised to contact the author for the final version of the publication, or visit the DOI to the publisher's website.

- The final author version and the galley proof are versions of the publication after peer review.

- The final published version features the final layout of the paper including the volume, issue and page numbers.

Link to publication

\footnotetext{
General rights rights.

- You may freely distribute the URL identifying the publication in the public portal. please follow below link for the End User Agreement:

www.umlib.nl/taverne-license

Take down policy

If you believe that this document breaches copyright please contact us at:

repository@maastrichtuniversity.nl

providing details and we will investigate your claim.
}

Copyright and moral rights for the publications made accessible in the public portal are retained by the authors and/or other copyright owners and it is a condition of accessing publications that users recognise and abide by the legal requirements associated with these

- Users may download and print one copy of any publication from the public portal for the purpose of private study or research.

- You may not further distribute the material or use it for any profit-making activity or commercial gain

If the publication is distributed under the terms of Article 25fa of the Dutch Copyright Act, indicated by the "Taverne" license above, 


\section{Urinary Incontinence and \\ Voiding Disorders in the Elderly}

Towards acceptable and applicable diagnostic evaluation 
CIP-DATA KONINKLIJKE BIBLIOTHEEK, DEN HAAG

Remmers, Ageeth

Urinary incontinence and voiding disorders in the elderly : towards acceptable and applicable diagnostic evaluation / Ageeth Remmers. - Maastricht : Universitaire Pers Maastricht. - III.

Thesis Maastricht. - With ref. - With summary in Dutch.

ISBN 90-5278-160-5

Subject Headings: urinary incontinence ; elderly

Ageeth Remmers, Maastricht 1994

Boekverzorging en omslagontwerp:

Datawyse | Universitaire Pers Maastricht 


\section{URINARY INCONTINENCE AND VOIDING DISORDERS IN THE ELDERLY}

towards acceptable and applicable diagnostic evaluation

\section{PROEFSCHRIFT}

ter verkrijging van de graad van doctor aan de Rijksuniversiteit Limburg te Maastricht, op gezag van de Rector Magnificus, Prof. dr. H. Philipsen, volgens het besluit van het College van Dekanen, in het openbaar te verdedigen op vrijdag 9 december 1994 om 14.00 uur

door

Ageeth Remmers

geboren op 22 juni 1961 te Muntendam

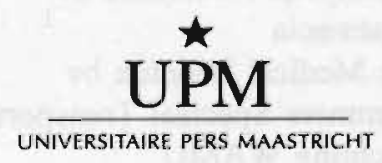


Promotor:

Copromoter:

Beoordelingscommissie: Prof. dr. P.G. Knipschild (voorzitter)

Prof. dr. H.J.M. Cools (Rijksuniversiteit Leiden)

Dr. J.F.B.M. Fiolet

Prof. dr. J.A. Knottnerus

Prof. dr. J. Troost

Financial support by: Abbott

AMT

Bekisting en betonwerk M. Hendrix-Geleen bv

Byk Nederland bv

Hoechst Holland nv

Installatiebedrijf Nilwik vof

MMS

Mölnlycke Nederland bv

Pharmacia

Pie Medical Benelux bv

Remmers Speciaal Transport

Stichting WAMU 
Aan mijn ouders 


\section{TABLE OF CONTENTS}

Chapter 1

Introduction

Chapter 2

Prevalence of Urinary Incontinence in Elderly People - a literature survey - . . 13

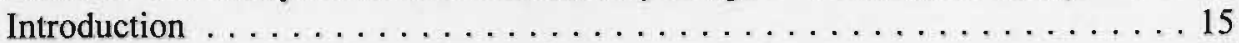

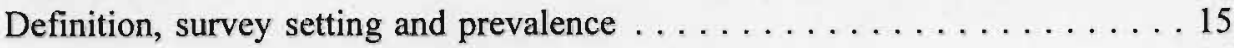

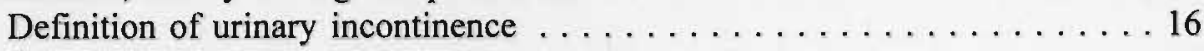

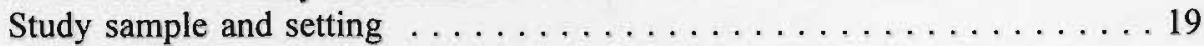

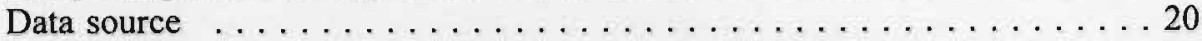

Data collection ......................... 20

Other factors that influence prevalence of urinary incontinence $\ldots \ldots \ldots 21$

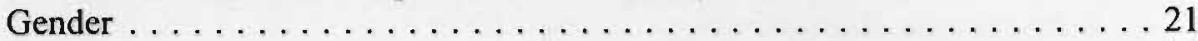

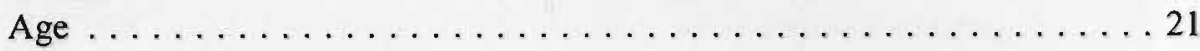

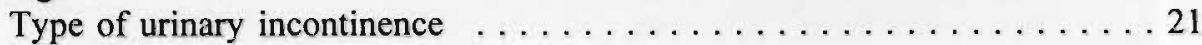

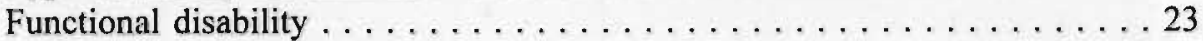

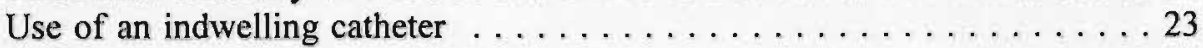

Parity . . . . . . . . . . . . . . . . . . 23

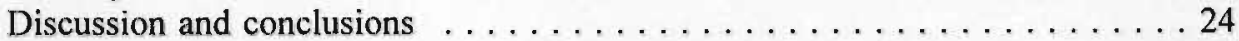

References .......................... 26

Chapter 3

Development of a Specific Questionnaire for Evaluation of

Lower Urinary Tract Function . . . . . . . . . . . . . . . . . . . 29

Introduction . . . . . . . . . . . . . . . . . . . 31

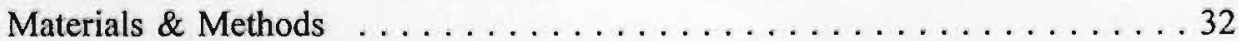

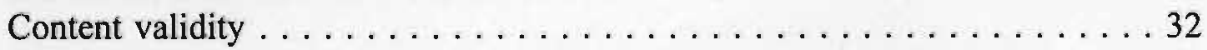

Face validity . . . . . . . . . . . . . . . . . 32

Criterion validity regarding the symptom of incontinence $\ldots \ldots \ldots \ldots 32$

Criterion validity regarding medical history classification $\ldots \ldots \ldots \ldots 32$

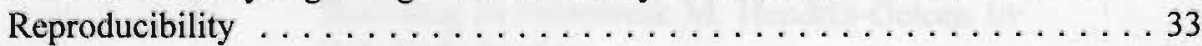

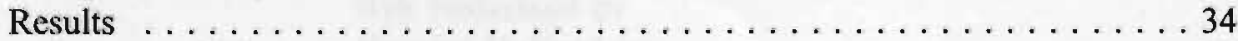

Content validity . . . . . . . . . . . . . . 34

Criterion validity regarding the symptom of incontinence $\ldots \ldots \ldots \ldots 34$

Criterion validity regarding medical history classification $\ldots \ldots \ldots \ldots 34$

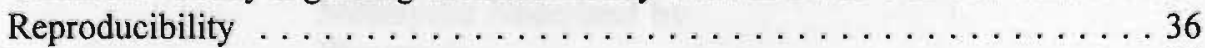

Discussion . . . . . . . . . . . . . . . . . . . . 36

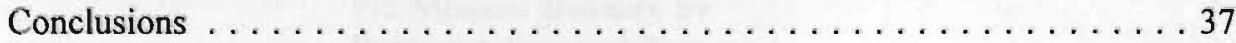

References . . . . . . . . . . . . . . . . . . . . 38 
Chapter 4

A Urinary Tract Questionnaire Survey in Homes for the Elderly . . . . . . . 39

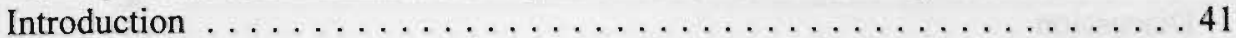

Materials \& Methods ..................... . 41

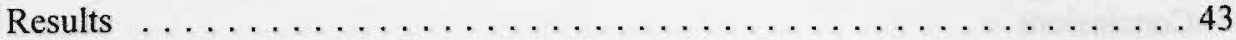

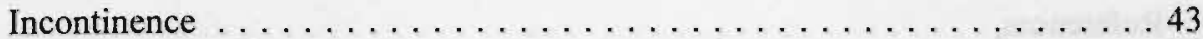

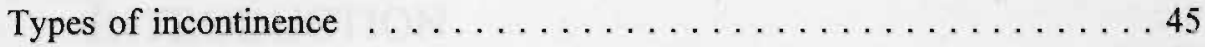

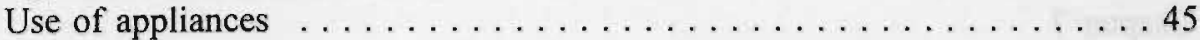

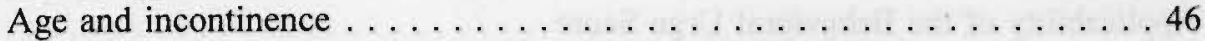

Lower urinary tract symptoms and incontinence $\ldots \ldots \ldots \ldots \ldots \ldots 4$

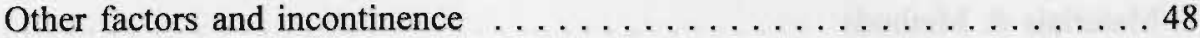

Discussion ... . . . . . . . . . . . . . . . . . . . . . . . 49

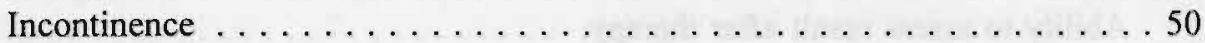

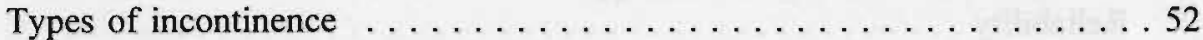

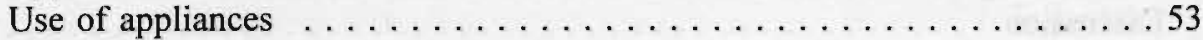

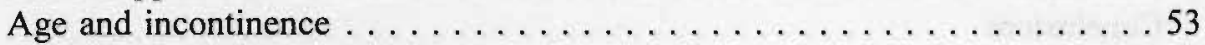

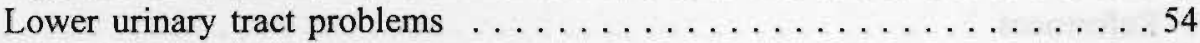

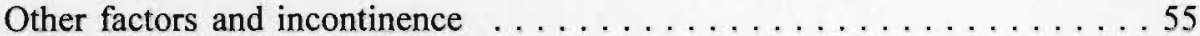

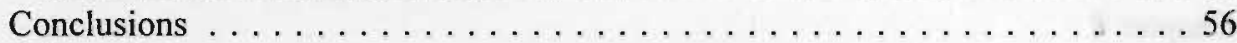

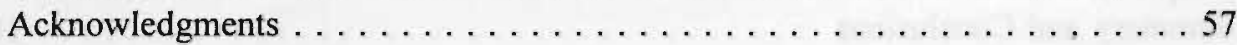

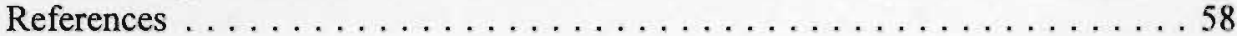

Chapter 5

Extramural Ambulatory Monitoring in Outpatients aged 60 and Over $\ldots \ldots 61$

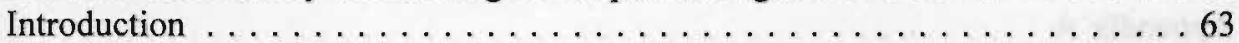

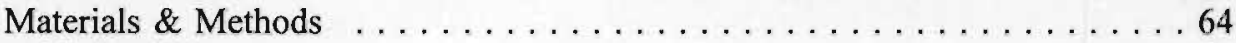

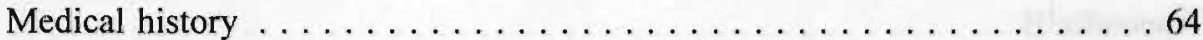

Conventional urodynamic investigation . . . . . . . . . . . . 64

Extramural ambulatory monitoring (EAM) $\ldots \ldots \ldots \ldots \ldots \ldots \ldots$

Subjective evaluation EAM . . . . . . . . . . . . . . . 65

Results .............................. 65

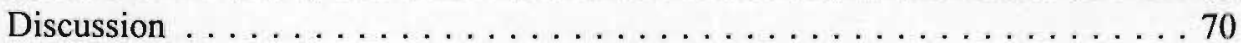

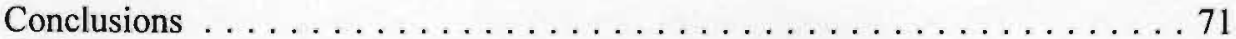

References .............................. 73

Chapter 6

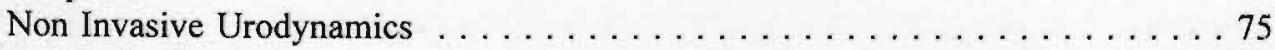

Introduction . . . . . . . . . . . . . . . . . . . . 77

Materials . . . . . . . . . . . . . . . . . . . . . . . 77

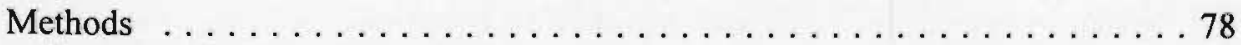

Frequency/volume chart $\ldots \ldots \ldots \ldots \ldots \ldots \ldots \ldots$

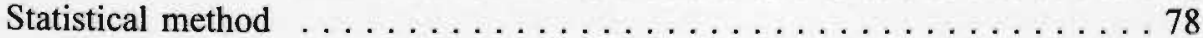

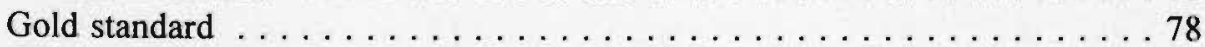

Conventional urodynamic investigation $\ldots \ldots \ldots \ldots \ldots \ldots \ldots$

Extramural ambulatory monitoring $\ldots \ldots \ldots \ldots \ldots \ldots$ 


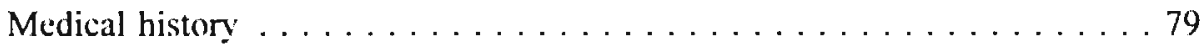

Results . . . . . . . . . . . . . . . . . . . . . . . . 79

Discussion . . . . . . . . . . . . . . . . 83

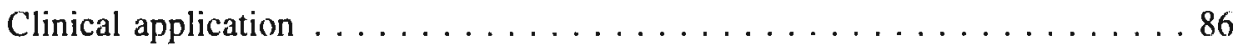

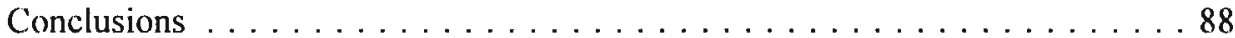

References . . . . . . . . . . . . . . . . . . . . . . . . . . . . . .89

Chapter 7

Applicability of the Behavioral Urge Score $\ldots \ldots \ldots \ldots \ldots \ldots \ldots \ldots$. $\ldots \ldots$

Introduction . . . . . . . . . . . . . . . . . . 93

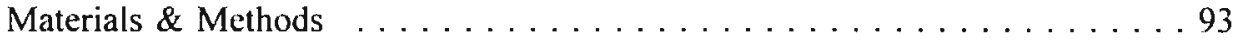

Results . . . . . . . . . . . . . . . . . . . . . . . . . .994

Ability to assess result after therapy. $\ldots \ldots \ldots \ldots \ldots \ldots \ldots \ldots 4$

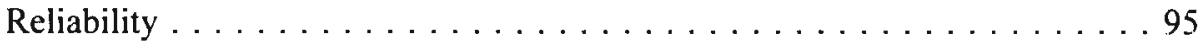

Discussion . . . . . . . . . . . . . . . . . . . .96

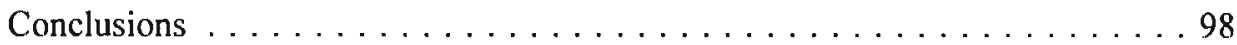

References ............................ . 99

Chapter 8

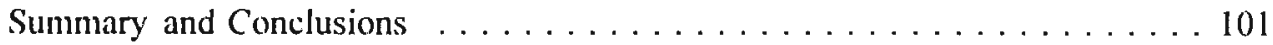

Chapter 9

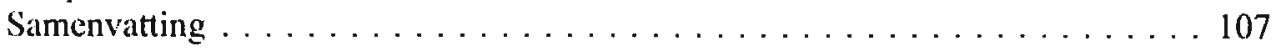

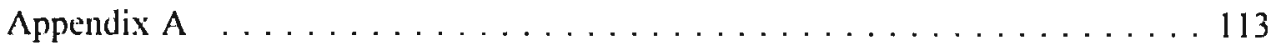

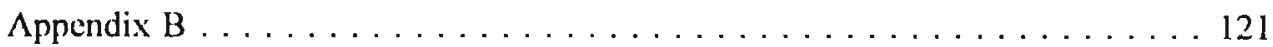

Acknowledgments. . . . . . . . . . . . . . . . . . . 127

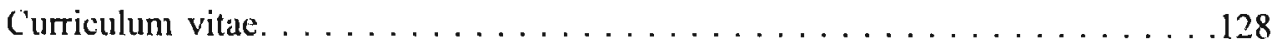




\section{INTRODUCTION}

\section{A. Remmers}

Department of Urology, University Hospital Maastricht, The Netherlands 

Over the last two decades increasing attention has been directed towards urinary incontinence and other lower urinary tract problems, by both the medical profession and patients. Urinary incontinence is a health problem with a high morbidity, although in most cases it is not directly associated with death. In this thesis we should like to underline the major role played by detrusor dysfunction as a causal mechanism in the development of incontinence. Until recently, little help could be offered to patients with lower urinary tract disorders.

With the high current standard of living, patients now expect more from the medical profession. Sophisticated tools and models (such as high-tech urodynamic investigations and ICS-standards) are being developed, larger amounts of money are being spent on good health and low morbidity. With the breaking of the taboo that used to lie on lower urinary tract disorders and especially incontinence, patients are encouraged to consult caregivers for proper treatment. Sophisticated, computerized, but expensive urodynamic equipment has been developed to meet the need for good diagnostics leading to adequate treatment. It is necessary to review this progress, as costs are increasing and patients are liable to become hospitalized. It is time to develop simple, low-cost, non-invasive diagnostic tools, using high quality urodynamic investigations as a standard.

In elderly people, the costs of urinary incontinence are high for other reasons (the term 'costs' as used here does not only mean costs in terms of money but also costs expressed as quality of life): - prevalence of urinary incontinence is high: since the aging of the body system influences mobility and bladder function, incontinence is more frequent in the elderly than in younger people; - elderly patients often do not want further investigation: they tend to accept incontinence as a part of old age or are unaware that help is available. Due to mental and physical handicaps especially prevalent in the frail elderly, it is difficult to perform an invasive urodynamic investigation prior to starting adequate treatment, this results in 'trial-and-errortreatment' or no treatment at all.

It is interesting to note that the ancient Romans had a life expectancy at birth of 22 years, while nowadays this is 75 years. The life expectancy at age 65 is 80 years. More people live to old age and old people live longer. Hence, it is to be expected that more people will suffer from urinary incontinence, and costs (economic and social) will rise accordingly.

In view of the above, the question arises whether and how the problem of lower urinary tract dysfunction, especially incontinence in the elderly, can be tackled in the near future. The present study has been performed to contribute to the solution of this problem.

It is first necessary to learn to what extent the problem of urinary incontinence and other lower urinary tract disorders exists in a population of elderly people. By means of a literature survey of studies performed to investigate the epidemiology of urinary incontinence and a questionnaire survey in a population of inhabitants of homes for the elderly, the magnitude of the problem was investigated. These studies revealed especially that the symptom urge, with or without incontinence, occurs relatively often. Since elderly people with lower urinary tract disorders are difficult to approach 
and since these elderly people have easy access to a general practitioner, it is likely to assume that simple diagnostic tools, applicable outside the hospital, are more accessible for these patients. Therefore, and since ambulatory urodynamics is especially of interest in case of detrusor overactivity in absence of voiding, the applicability of extramural ambulatory monitoring in an elderly population was investigated and evaluated. But, for the interpretation of extramural ambulatory monitoring special knowledge is necessary and further simplification of diagnosing is of interest. Frequency/volume charts are widely used and give the physician an indication of the patient's bladder behaviour. Low physiologic bladder capacity is an indicator for urge incontinence, as is frequency. With the development of advanced urodynamics including ambulatory techniques, the demonstration and quantification of detrusor overactivity becomes very close to a 'gold standard'. Therefore, it makes sense to reevaluate the frequency/volume chart. New knowledge can be used to improve the chart and calibration against the gold standard is possible. Sensitivity and specificity can be measured and clinically relevant cutoff points can be established to prevent unnecessary invasive investigations.

In summary, the aims of the project are:

- to study the epidemiologic aspects of lower urinary tract dysfunction in the elderly:

a. in the literature;

b. in a population of inhabitants of homes for the elderly;

- to evaluate extramural ambulatory urodynamics as a relatively simple diagnostic tool in a group of outpatients aged 60 and over;

- to develop and assess the applicability of a frequency/volume chart, for scoring bladder activity qualitatively and quantitatively, as a simple diagnostic tool.

Chapter 2 gives an overview of the international literature on the prevalence of urinary incontinence and other lower urinary tract disorders. In chapter 3 the development of a specific questionnaire for the assessment of lower urinary tract function for the elderly is described. The results of a study for the epidemiology of lower urinary tract dysfunction in homes for the elderly is decribed in chapter 4 . In chapter 5 a first step towards the development of simple and low-cost urodynamics, applicable in the primary echelons of health care is described, i.e., extramural ambulatory monitoring in outpatients aged 60 and over. This is followed by the development of the behavioral urge score or BUS, a non-invasive tool that predicts the existence of bladder overactivity during the filling phase based on frequency/volume chart variables (drinking and voiding). The results of this study are described in chapter 6 . Since a new diagnostic tool needs validity and reliability assessment, a study was performed to fulfil this need, of which the results are given in chapter 7. Chapter 8 summarizes all results showing that, although not complete, an applicable assessment of urinary tract dysfunction in this not easily accessible patient group becomes feasible. In this way the effectiveness of the substantial sums spent on this specific health problem can be improved. 


\title{
PREVALENCE OF URINARY INCONTINENCE IN ELDERLY PEOPLE - A LITERATURE SURVEY -
}

\begin{abstract}
This study was performed to assess the prevalence of urinary incontinence in elderly people by means of a literature review. The relationship between age, functional disability, use of an indwelling catheter, parity and incontinence was evaluated. It is difficult to indicate precisely the prevalence of urinary incontinence: the studies discussed here have been carried out in various settings, with different methods of data collection, and using different definitions of urinary incontinence. Categorizing the different studies for study setting, data source and definition of urinary incontinence used still gives different prevalence estimates. If only studies fulfilling certain criteria (validated questionnaire, performed among both males and females to make comparisons possible, description of the population under study, random sampling, good response rate) are considered, just three meet these standards. Prevalences of urinary incontinence in these studies were, respectively, $25 \%, 15.3 \%$ and $22.2 \%$ in elderly males and $42 \%, 25.8 \%$ and $37.1 \%$ in elderly females (measured from the age of 60 and upwards). It can be concluded, that in the future more surveys are needed to establish reliable prevalence estimates among both males and females.
\end{abstract}

\footnotetext{
A. Remmers

Department of Urology, University Hospital Maastricht, The Netherlands

submitted for publication
} 


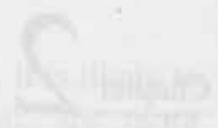

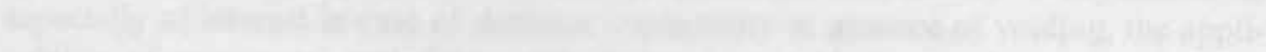

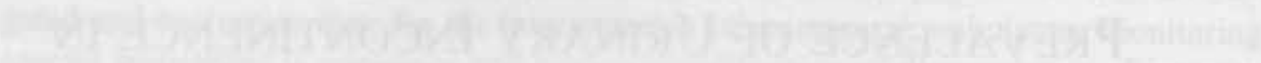

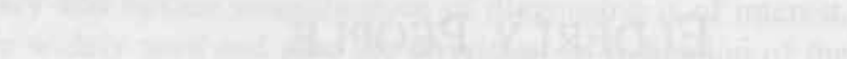
10 


\section{INTRODUCTION}

Lower urinary tract dysfunction and especially urinary incontinence are relatively common problems among elderly persons. With increased average life span, it is likely that the problem will grow quantitatively. Qualitatively, urinary incontinence can be a great burden, for patients as well as health-care personel. Starer ${ }^{1}$ surveyed clinical records in a nursing home for reasons for admission. After mobility problems $(56.2 \%)$ and dementia $(48.1 \%)$, incontinence scored as a priority problem or diagnosis on admission in $11.2 \%$ of cases.

Involuntary loss of urine often implies a diminished freedom of movement and therefore restricted social involvement. The financial impact of urinary incontinence is substantial, both for patients and for the institutionalized health care system. ${ }^{2,3,4}$ There has been some progress in the management and treatment of urinary incontinence, but incontinent people - especially elderly ones - are not likely to seek medical help. ${ }^{5}$ To estimate the size of the problem in order to formulate a rational policy, many investigators have published on the prevalence of urinary incontinence in the community and in institutional care. The results of these surveys vary widely, partly due to the definition of incontinence used, and partly due to the different methodological measures and survey settings used. Also, the mechanisms, clinical presentation and causes of urinary incontinence are complex and varied.

This study has been conducted to categorize and compare estimates of the prevalence of urinary incontinence in the population (community-residing and in long-term institutional care), as published in the international literature.

\section{DEFINITION, SURVEY SETTING AND PREVALENCE}

Table 1 gives an overview of 25 selected urinary incontinence prevalence studies (medline search 1989-1991; keywords: urinary incontinence, prevalence, epidemiology). Since the population under study influences prevalence estimates, a division has been made in surveys in the community only, surveys in both the community and long-term institutions and surveys in long-term institutions only. Prevalence estimates vary considerably. In studies performed in both community settings and institutions, percentages vary between 8.7 and 38.2 when the male population is the subject of study, between 12 and 49 for female incontinence, and between 11.6 and 40.6 when both females and males are investigated (see tabel 1). In studies performed in community settings only, incontinence occurs in $5.7-22.2 \%$ of the males, in 13.9 $40.1 \%$ of the females, and in $9.2-53 \%$ of both males and females. In long-term institutional care prevalence varies between $27 \%$ and $50.5 \%$. The distinction between figures for males and females and combined figures is made because some authors state only an overall percentage and others mention separate percentages only. 


\section{CHAPTER 2}

Table 1. Overview of urinary incontinence prevalence estimates.

\begin{tabular}{|c|c|c|c|c|}
\hline & \multirow[b]{2}{*}{ author(s) } & \multicolumn{3}{|c|}{ prevalence (\%) } \\
\hline & & all & males & females \\
\hline \multirow{10}{*}{$\begin{array}{l}\text { studies } \\
\text { in } \\
\text { both } \\
\text { community } \\
\text { settings } \\
\text { and } \\
\text { institutions }\end{array}$} & Britton $^{6}$ & & 27 & \\
\hline & Campbell $^{7}$ & 11.6 & & \\
\hline & McGrother $^{8}$ & 12 & 12 & 12 \\
\hline & Mellström ${ }^{9}$ & & & 46 \\
\hline & Milne $^{10}$ & 34.5 & 25 & 42 \\
\hline & Molander $^{11}$ & & & 16.9 \\
\hline & Thomas $^{12}$ & 21.5 & 8.7 & 17.1 \\
\hline & Vehkalahti ${ }^{13}$ & 40.6 & 38.2 & 41.3 \\
\hline & Yarnell $^{14}$ & 14 & 11 & 17 \\
\hline & Yarnell $^{15}$ & & & 49 \\
\hline \multirow{10}{*}{$\begin{array}{l}\text { studies } \\
\text { in } \\
\text { community } \\
\text { settings }\end{array}$} & Diokno $^{16}$ & 30.0 & 18.9 & 37.7 \\
\hline & Feneley $^{17}$ & & 5.7 & 13.9 \\
\hline & Herzog ${ }^{18}$ & 30 & 19 & 38 \\
\hline & Holst $^{5}$ & & & 34.3 \\
\hline & Jagger $^{19}$ & 9.2 & & \\
\hline & Jolleys $^{20}$ & & & 25 \\
\hline & $\mathrm{Kok}^{21}$ & & & 23.4 \\
\hline & Noelker $^{22}$ & 53 & & \\
\hline & Taesdale $^{23}$ & 33.4 & 22.2 & 37.3 \\
\hline & Vetter $^{24}$ & 13.8 & 7.3 & 18.1 \\
\hline \multirow{5}{*}{$\begin{array}{c}\text { studies } \\
\text { in } \\
\text { institutions }\end{array}$} & Ekelund $^{25}$ & 27 & 32 & 25 \\
\hline & Ouslander $^{26}$ & 50 & & \\
\hline & Ribeiro $^{27}$ & 50.5 & & \\
\hline & Starer $^{1}$ & 36 & & \\
\hline & Tobin ${ }^{28}$ & 32 & 23 & 33 \\
\hline
\end{tabular}

\section{Definition of urinary incontinence}

The standardisation committee of the International Continence Society has defined urinary incontinence as 'involuntary urine loss which is objectively demonstrable and a social or hygienic problem'. Loss of urine through channels other than the urethra is called extraurethral incontinence. Urinary incontinence denotes: 1) a symptom: the patient's statement of involuntary loss, 2) a sign: the objective demonstration of urine 
loss, and 3) a condition: the urodynamic demonstration of urine loss. ${ }^{29}$ Using this definition, urinary incontinence should meet certain criteria in order to be regarded as a clinically significant problem.

A definition that can be used in the epidemiological surveys discussed here, which have mostly taken the form of personal or postal interviews, is difficult to establish. Incontinence should be defined in terms of quality (inappropriate places, inappropriate times) and in terms of quantity (amount and frequency of loss). An objective demonstration of incontinence is hardly possible in these studies. In those community based surveys in which the authors have tried to objectify incontinence, many persons dropped out. ${ }^{7,11,18}$ This is probably due to the delicacy of the problem and the embarrassment a lot of people feel about their incontinence.

Definitions used in the surveys discussed here vary considerably, see table 2. Table 3 shows prevalence estimates on the basis of the definition 'any involuntary loss of urine'; table 4 does the same for a more restricted definition. The definition of urinary incontinence based upon questions like 'do you have any difficulty in controlling your water ${ }^{7,8}$ is considered to be more restricted, since persons who do lose urine at some time may not regard this as a difficulty. Also, the period of time over which the incontinence persists should be considered in the definition of urinary incontinence. Otherwise, subjects with only one incontinence episode in the past (for instance females just after delivery or during pregnancy), are regarded as urinary incontinent. Despite the subdivision made, prevalence estimates still vary considerably.

Underreporting might play a major role, since it is likely that respondents cannot deny or forget severe loss as easily as they might in the case of mild loss. In order to establish the prevalence of clinically significant incontinence, some authors have investigated whether respondents would like to seek or did seek professional help, or use diapers, and/or have asked how often the incontinence occurred. ${ }^{5,8,12,18,24}$ All reported a relation between the frequency of incontinence and the request for professional help and/or the use of diapers.

Table 2a. Definitions of urinary incontinence including 'any involuntary loss of urine'.

any involuntary loss of urine involuntary loss of urine with a minimum frequency of 6 days during the past 12 months any inappropriate leakage of urine at least 1 episode of urine loss in the past 6 months wetness on the way to the toilet, while coughing or sneezing, at night when asleep 


\section{CHAPTER 2}

Table 2b. More restricted definitions of urinary incontinence.

involuntary loss of urine twice a month or more

involuntary loss of urine constituting a social or hygienic problem

difficulty in controlling water

any urine loss twice or more per week

involuntary urine loss that is a social or hygienic problem and is objectively demonstrable problem in controlling urine

involuntary loss of urine once per week or more often

daily involuntary urine loss

Table 3. Prevalence estimates (in percentages) of urinary incontinence in elderly people, using 'involuntary loss of urine regardless of frequency or amount' to define urinary incontinence.

prevalence (\%)

'any involuntary loss'

\begin{tabular}{|c|c|c|c|c|}
\hline & author(s) & all & males & females \\
\hline \multirow{7}{*}{$\begin{array}{l}\text { studies } \\
\text { in } \\
\text { both } \\
\text { community } \\
\text { settings } \\
\text { and } \\
\text { institutions }\end{array}$} & Britton $^{6}$ & & 27 & \\
\hline & Campbell $^{7}$ & 11.6 & & \\
\hline & Milne $^{10}$ & 34.5 & 25 & 42 \\
\hline & Thomas $^{12}$ & 21.5 & 15.3 & 25.8 \\
\hline & Vehkalahti ${ }^{13}$ & 40.6 & 38.2 & 41.3 \\
\hline & Yarnell $^{14}$ & 14 & 11 & 17 \\
\hline & Yamell $^{15}$ & & & 49 \\
\hline \multirow{4}{*}{$\begin{array}{l}\text { studies } \\
\text { in } \\
\text { community } \\
\text { settings }\end{array}$} & Holst $^{5}$ & & & 34.3 \\
\hline & Jagger $^{19}$ & 9.2 & & \\
\hline & Jolleys $^{20}$ & & & 25 \\
\hline & Noelker $^{22}$ & 53 & & \\
\hline \multirow{2}{*}{$\begin{array}{l}\text { studies in } \\
\text { institutions }\end{array}$} & Ouslander ${ }^{26}$ & & 40 & 50 \\
\hline & Ribeiro $^{27}$ & 50.2 & & \\
\hline
\end{tabular}


Table 4. Prevalence estimates (in percentages) of urinary incontinence in elderly people, using a more restricted definition of urinary incontinence.

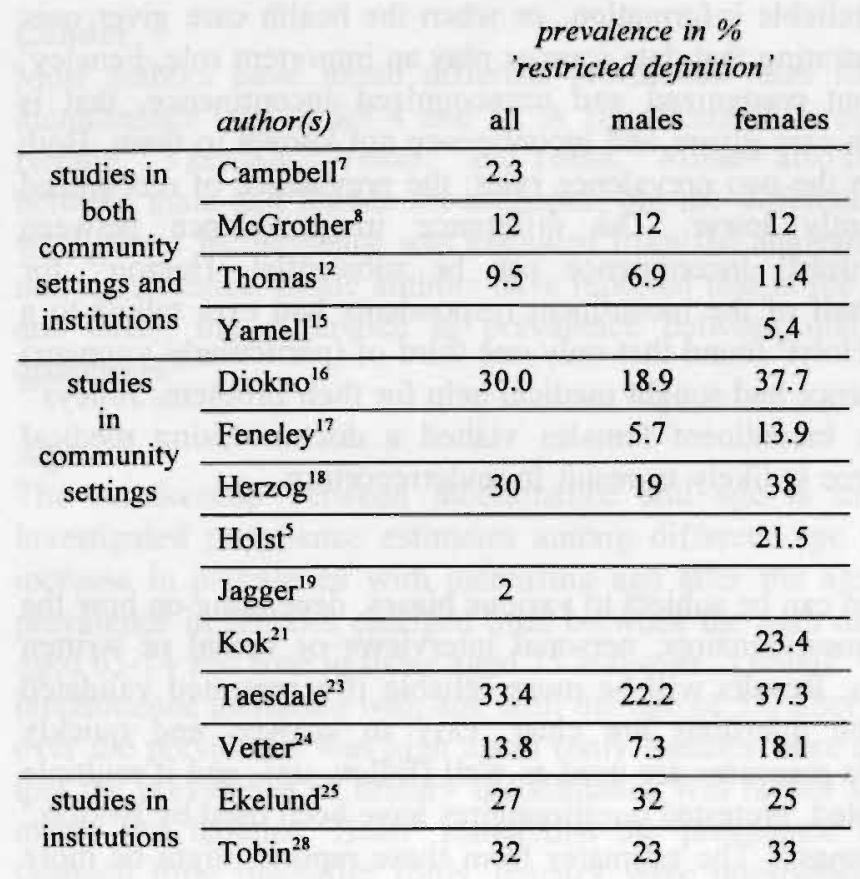

\section{Study sample and setting}

Prevalence estimates have usually been the highest, with the narrowest range, among elderly people living in long-term institutional care (see table 1). There seems to be a relation between physical/mental status and incontinence. Campbell ${ }^{7}$ reported that dementia was clearly associated with an increased risk of urinary incontinence. Several data sources (relatives, medical staff, patient records, the patients themselves) were used, which probably makes the prevalence estimates quite reliable. In studies performed in community settings or both community settings and institutions, prevalences diverge more; numbers reported by Vehkalahti ${ }^{13}(40.6 \%)$ and Noelker ${ }^{22}$ (53\%) are particularly high. This may well be due to the study sample: Vehkalahti interviewed males and females aged 84 or 85 , while Noelker questioned spouses or adult children who were helping the elderly person concerned with one or more personal care tasks. Both are populations in which a high prevalence of urinary incontinence could be expected: the very old are more likely to suffer from the problem, due to aging of the body system, and the same is true for those who are dependent on others. 


\section{Data source}

The way the data are gathered gives rise to different prevalence estimates. Underreporting occurs when people do not volunteer to visit health care givers, when the data source provides unreliable information, or when the health care giver uses inadequate data sources. Illustrating that data sources play an importent role, Feneley ${ }^{7}$ and Thomas ${ }^{12}$ reported about recognized and unrecognized incontinence, that is incontinence known to health care givers and incontinence not known to them. Both found a discrepancy between the two prevalence rates: the prevalence of recognized incontinence was significantly lower. The difference in prevalence between 'recognized' and 'unrecognized' incontinence can be substantial. Herzog ${ }^{18}$ for instance reported that only half of the incontinent respondents had ever talked to a doctor about their problem. Holst ${ }^{5}$ found that only one third of (particularly younger) females with severe incontinence had sought medical help for their problem. Jolleys ${ }^{20}$ reported that $8-18 \%$ of the incontinent females visited a doctor. Using medical records as the only data source is likely to result in underreporting.

\section{Data collection}

The method of data collection can be subject to various biases, depending on how the data are collected: mailed questionnaires, personal interviews or verbal or written reports by health care givers. Results will be more reliable if a pretested validated questionnaire is used, if the questions are clear, easy to answer, and quickly completed, if other diagnostic measures are used as well (follow-up), and if multiple data sources are used. Validated, pretested questionnaires have been used by Britton, ${ }^{6}$ Milne, ${ }^{10}$ Taesdale, ${ }^{23}$ and Thomas. ${ }^{12}$ The estimates from these reports might be more reliable and less polluted by unreliable questions.

Follow-up studies have been performed by several authors. ${ }^{8,11,18} \mathrm{McGrother}^{8}$ found a confirmation of the urinary dysfunction in $8 \%$ of the $10 \%$ of the original sample who were living in the community and suffering from non-catheterized urinary dysfunction. The remaining $2 \%$ became terminally ill or entered hospital, migrated, denied a significant problem or refused follow-up in the intervening period. Molander ${ }^{11}$ reinvestigated a subgroup of 300 from her original 677 patients and found that, in 14 cases $(4.6 \%)$ it was not possible to confirm the diagnosis of urinary incontinence by objective means. Herzog ${ }^{18}$ found $83 \%$ agreement for each sex between self-reports and the clinician's assessment in a subset of the original sample. The agreement with the clinician's assessment for female continence and incontinence was $87 \%$ and $79 \%$ respectively; in males this was $85 \%$ and $76 \%$ respectively. Relying on the respondent's answer might thus give rise to overreporting. 


\section{OTHER FACTORS THAT INFLUENCE PREVALENCE OF URINARY INCONTINENCE}

\section{Gender}

Most authors have found different prevalence rates for male and female urinary incontinence (see tables 4 and 5). A significant difference was found by Diokno, ${ }^{16}$ Herzog, ${ }^{18}$ Taesdale, ${ }^{23}$ Vetter, ${ }^{24}$ and Tobin. ${ }^{28}$ Milne ${ }^{10}$ also found a significant difference between male and female incontinence, but the difference was no longer significant when stress incontinence was excluded from the analysis. Vehkalahti ${ }^{13}$ also reported non-significance. Some authors have reported that in the very old ( 75 and over or 80 and over), the difference in prevalence between male and female incontinence disappears. ${ }^{8,12,14}$

\section{Age}

The relationship between incontinence and age is unclear. Some authors have investigated prevalence estimates among different age groups. Thomas ${ }^{12}$ found an increase in prevalence with increasing age after the age of 35 in males, while the prevalence in females changed little between the ages of 35 and 64 but fell in those aged 65-74 and rose in those aged 75 and over. Yarnell ${ }^{14}$ found that the prevalence of incontinence increased with age until the age of 55, after which it fell. At age 75 and over the prevalence was high again (only females were questioned). Feneley ${ }^{17}$ found that the prevalence of urinary incontinence was higher above the age of 65 , in both males and females. Holst ${ }^{5}$ stated that the prevalence increased until age 25 , but changed little thereafter (only females were questioned); the prevalence of stress incontinence fell after age 55, while urge and mixed incontinence increased after age 65. Jolleys ${ }^{20}$ found that incontinence was significantly more prevalent among premenopausal compared to postmenopausal females; the prevalence increased with age until the 45-54 age group, after which it fell; above age 65 the prevalence rate no longer changed.

\section{Type of urinary incontinence}

In personal and postal interviews questions can be asked about the circumstances in which urine is lost, to enable one to decide on the type of incontinence (stress, urge, mixed, other). Table 5 shows the prevalence estimates of the different types of urinary incontinence, together with the questions/definitions used. The International Continence Society (ICS) definitions of the different types of incontinence are as follows. Stress incontinence: the symptom indicates the patient's statement of involuntary urine loss during physical exertion. Urge incontinence: involuntary urine loss associated with a strong desire to void (urgency). ${ }^{29}$ The definitions used in the studies discussed here do not differ very much from the ICS definitions. 


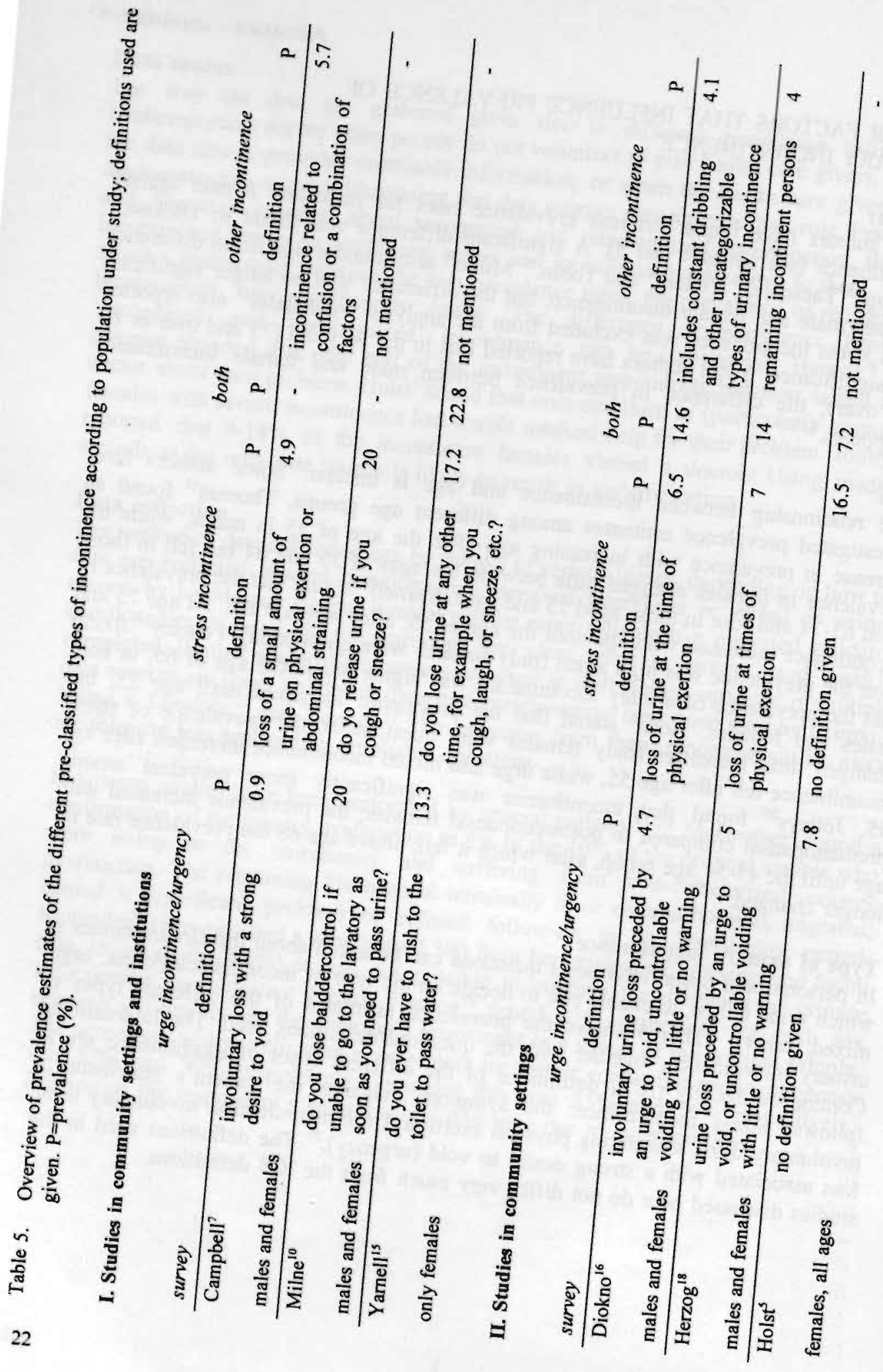


The prevalence of urge incontinence among elderly subjects varies between $0.9 \%$ and $20 \%$, stress incontinence between $4.9 \%$ and $20 \%$. In females the stress or mixed type is more prevalent than the urge type, while in males urge incontinence prevails. Yarnel ${ }^{15}$ reported a relation between the severeness of the incontinence (in terms of frequency and amount) and the type of incontinence: the stress type alone was a relatively common but usually mild complaint, whereas the mixed type was less common but more severe.

\section{Functional disability}

Surveys ${ }^{7,13,14}$ from both community and institutional settings investigating differences in the prevalence of incontinence between the two settings have reported higher prevalence rates of urinary incontinence in subjects living in institutions. Subjects with dementia, poor mobility and poor physical health were more likely to be incontinent. Cools ${ }^{30}$ also reported, in a study performed in both the general population and nursing homes, that someone is more likely to suffer from urinary incontinence in case of restrictions in movement, changing position, goaldirected action, communication and condition.

\section{Use of an indwelling catheter}

If all catheterized subjects are considered incontinent this means an overestimation of the problem, since catheters are not only applied for urinary incontinence. On the other hand, if persons using a catheter are excluded, the prevalence rate might be underestimated.

This is especially important in studies performed among subjects living in. institutions, where the prevalence of catheter use is higher. Of five studies performed in an institutional setting, three explicitly mention catheter use. ${ }^{25.27}$ Ouslander ${ }^{26}$ considered subjects with an indwelling catheter as urinary incontinent, except when the catheter has been applied to relieve a hypotonic bladder or an outlet obstruction. Ekelund $^{25}$ and Ribeiro ${ }^{27}$ considered the group with a catheter separately from the continent and incontinent groups. Studies performed in community settings as well as in institutional settings rarely consider catheterized subjects separately. Vehkalahti ${ }^{13}$ regarded subjects using an indwelling catheter as urinary incontinent; this was the case in $21 \%$ of the investigated males and females. Feneley ${ }^{17}$ also regarded subjects with a catheter as incontinent, but they represented only a small proportion of cases ( $7 \%$ of incontinent males and $1 \%$ of the incontinent females used a catheter or appliances).

\section{Parity}

In females, there seems to be a relation between parity and urinary incontinence, although this relation is not clear. Ekelund ${ }^{25}$ reported that incontinence was more common in females who had delivered three or more children, while there was no difference between nulliparous females and females with 1 or 2 children. Holst ${ }^{5}$ found that incontinence was reported significantly less frequently by nulliparous females than by those with one child, while prevalence changed little with increasing parity. Hørding ${ }^{31}$ did not find any significant differences in prevalence between 
nulliparous females and the females in the whole series; neither was there any significant difference in parity between stress incontinent females and the whole series. Kok ${ }^{21}$ did not find a relation between incontinence and parity. Thomas ${ }^{12}$ found that incontinence was reported less commonly by nulliparous compared to parous females at all ages. But, except in the 45-54 age group, incontinence was no more common in those who had had two or three babies than in those who had had only one. Females who had had four or more babies were most likely to report regular incontinence.

\section{DISCUSSION AND CONCLUSIONS}

Many questions about the epidemiology of urinary incontinence remain unanswered. It is difficult to establish the precise prevalence of urinary incontinence, since the studies discussed here have been performed in various settings, using different methods of data collection, and different definitions of urinary incontinence. Categorizing the different studies for study setting and definition of urinary incontinence used, it can be seen (tables 3 and 4) that there is still some variance in prevalence estimates in studies performed in the community only and in those performed in both community and institutional care settings. In studies performed in institutional care settings only the prevalence of severe urinary incontinence lies around $30 \%$. These studies used multiple data sources (relatives, medical staff, patient records, the patients themselves), which probably makes the prevalence estimates quite reliable.

Those who investigated severeness of incontinence and the proportion of sufferers seeking health care reported that there was a relation between the frequency of incontinence episodes and the applications for professional help and/or the use of diapers. Therefore, considering severity of incontinence in terms of frequency and amount might yield more reliable prevalence estimates than using 'any involuntary urine loss' to define urinary incontinence. This is especially true with respect to the ICS definition: the patient's statement of urinary incontinence should be objectively demonstrable. More severe incontinence is more likely to be objectively demonstrable. Furthermore, subjects with daily incontinence are probably more severly socially disabled by their incontinence; this is the group to which therapy and education should primarily be directed.

Considering surveys performed in the community or in both community and institutions (tables 3, 4, and 5) it is notable that the numbers found by Vehkalahti ${ }^{13}$ and Noelker ${ }^{22}$ are higher than those found by others. These studies were both performed in populations in which a high prevalence of urinary incontinence could be expected: respectively, males and females aged 84 or over and elderly people who need help with one or more personal care tasks. These are populations in which high percentages of functional disabilities can be expected and which therefore have high prevalence estimates.

Using a questionnaire as the method of data collection may have led to overreporting. since incontinence could not always be objectified. It is possible that wetting occurs 
under exceptional circumstances not detected during objective investigations. In that case the question arises whether the incontinence was clinically significant. It is also likely that the patients denied being incontinent, which could tip the balance both ways. From Herzog's study ${ }^{18}$ it can be concluded that results of a questionnaire survey might also be subject to underreporting since, apparently, some people do not volunteer their urinary incontinence in a questionnaire or may even deny the problem. Some authors have mentioned different prevalence estimates for males and females. Since in the very old these differences were not significant and urge incontinence is more prevalent among the very old, differences in male and female incontinence prevalence might be due to the occurrence of stress incontinence. This has been objectified by Milne. ${ }^{10}$

The investigated surveys do not allow a clear conclusion about whether there is a relation between incontinence and parity. This relation is probably less clear in elderly females compared to younger females, since in elderly females other factors, such as mobility or general impairment, might contribute to the incontinence.

In studies that investigate prevalence of urinary incontinence and other voiding disorders in a general population, it is important that the questionnaire used is validated. Furthermore, it is of importance that the population under study is described sufficiently, that response rate is given, and that, in case of sampling, this is performed in a random manner. It is also interesting to have separate prevalence estimates in males and females, to make comparisons possible. Only 3 of the 20 discussed studies meet these criteria, those performed by Milne, ${ }^{10}$ Thomas $^{12}$ and Taesdale. ${ }^{25}$ These surveys report prevalence estimates of, respectively, $25 \%, 15.3 \%$ and $22.2 \%$ in elderly males and $42 \%, 25.8 \%$ and $37.1 \%$ in elderly females, measured from the age of 60 and upwards. The numbers still differ, which cannot be explained by the applied definition of urinary incontinence. The differences are mainly due to differences in survey setting and method of data collection. Regional differences might also play an important role. It can be concluded that in the future more surveys are needed to establish reliable prevalence estimates among both males and females. In institutional settings the method of data collection and survey setting is somewhat different. Often, a questionnaire is not the method of first choice, since these persons are mentally or physically handicapped in such a way that questions cannot be answered adequately. The discussed surveys are performed in geriatric care, except for the survey by Tobin, which has been performed among inhabitants of a residential home. In these studies prevalences are more in agreement (see tables 1, 3 and 4), which is due to the more reliable method of data collection (several sources).

To establish reliable prevalence estimates for urinary incontinence, surveys are needed, that are performed with a validated questionnaire, that investigate both the male and the female population, that describe the surveyed population, that mention response rate, and that collect data from a random sample (in case sampling is performed). When considering treatment options in the near future, it is also important to consider the type of urinary incontinence, as this may have a considerable impact on diagnostic and/or therapeutic guidelines. 


\section{REFERENCES}

\section{Starer P, Libow LS}

Obscuring Urinary Incontinence - Diapering of the Elderly

J Am Geriatr Soc 1985; 33: 842-846

2. Hu TW

The economic impact of urinary incontinence

Clinics in Geriatric Medicine 1986; 2: 673-687

3. Ouslander JG, Kane RL

The costs of urinary incontinence in nursing homes

Medical Care 1984; 22: 69-79

4. Townsend $\mathbf{J}$

Costs of incontinence

Community Medicine 1988; 10: 235-239

5. Holst K, Wilson PD

The prevalence of female urinary incontinence and reasons for not seeking treatment NZ Med J 1988; 756-758

6. Britton JP, Dowell AC, Whelan P

Prevalence of urinary symptoms in men aged over 60

Br J Urol 1990; 66: 175-176

7. Campbell AJ, Reinken J, McCosh L

Incontinence in the elderly: prevalence and prognosis

Age and ageing 1985; 14:65-70

8. MeGrother CW, Castleden CM, Duffin H, Clarke M

Provision of Services for Incontinent Elderly People at Home

J Epid Comm Health 1986; 40: 134-138

9. Mellström D

Epidemiological Aspects of Urogenital Complaints in older Women

Acta Obstet Gynecol Scand Suppl 140, 11-17

10. Milne JS, Williamson J, Maule MM, Wallace ET

Urinary symptoms in older people

Modern Geriatrics 198-212

I1. Molander U, Milsom I, Ekelund P, Mellström D

An epidemiological study of urinary incontinence and related urogenital symptoms in elderly women

Maturitas 1990; 12: $51-60$

12. Thomas TM, Plymat KR, Blannin J, Meade TW

Prevalence of Urinary Incontinence

Br Med J 1980: 281: 1243-1245

13. Vehkalahti I, Kivelä S-L

Urinary Incontinence and Its Correlates in Very Old Age

Gerontology 1985; 31: 391-396

14. Yarnell YWG, St. Leger AS

The prevalence, severity and factors associated with urinary incontinence in a random sample of the elderly

Age and Ageing 1979; 8: 81-85

15. Yarnell JWG, Voyle GJ, Richards CJ, Stephenson TP

The prevalence and severity of urinary incontinence in women

J Epid Comm Health 1981; 35: 71-74 
16. Diokno AC, Brock BM, Brown MB, Herzog RA

Prevalence of umiary incontinence in the noninstitutionalized elderly

J Urol 1986; 136: 1022-1025

17. Feneley RCL, Shepherd AM, Powell PH, Blannin J

Urinary incontinence: prevalence and needs

Br J Urol 1979; 51: 493-496

18. Herzog AR, Fultz NH, Normolle DP, Brock BM, Diokno AC

Methods used to manage urinary incontinence by older adults in the community JAGS 1989; 37: 339-347

19. Jagger C, Clarke M, Davies RA

The elderly at home: indices of disability

J Epid Comm Health 1986; 40: 139-142

20. Jolleys JV

Reported Prevalence of Urinary Incontinence in Women in a General Practice

Br Med J 1988; 296: 1300-1302

21. Kok ALM, Voorhorst FJ, Halff-Butter CMC, Janssens J, Kenemans P

De prevalentie van urine-incontinentie bij oudere vrouwen

NtvG 1991; 135: 98-101

22. Noelker LS

Incontinence in elderly cared for by family

Gerontologist 1987; 27: 194-200

23. Taesdale TA, Taffet GE, Luchi RJ, Adam E

Urinary incontinence in a community-residing elderly population

JAGS 1988; 36: 600-606

24. Vetter NJ, Jones DA, Victor CA

Urinary incontinence in the elderly at home

The Lancet 1981; 1275-1277

25. Ekelund P, Rundgren $\AA$

Urinary incontinence in the elderly with implications for hospital care consumption and social disability

Arch Gerontol Geriatr 1987; 6: 11-18

26. Ouslander JG, Kane RL, Abrass IB

Urinary Incontinence in Elderly Nursing Home Patients

JAMA 1982; 248: 1194-1198

27. Ribeiro BJ, Smith SR

Evaluation of urinary catheterization and Urinary incontinence in a general nursing home population

JAGS $1985 ; 33: 479-482$

28. Tobin GW, Brocklehurst JC

The Management of Urinary Incontinence in Local Authority Residential Homes for the Elderly Age and Ageing 1986; 15: 292-298

29. Abrams P, Blaivas JG, Stanton SL, et al

The standardisation of terminology of lower urinary tract function.

Scand J Urol Nephrol (suppl) 1988; 114: 5-19

30. Cools HJM, Bock GH de

De samenhang van ongewenst urineverlies met andere beperkingen in het functioneren

NTvG 1993; 137: 1828-1830

31. Hording U, Pedersen KH, Sidenius K, Hedegaard L

Urinary incontinence in 45-year old women

Scand J Urol Nephrol 1986; 20: 183-186 


\title{
DEVELOPMENT OF A SPECIFIC QUESTIONNAIRE FOR EVALUATION OF LOWER URINARY TRACT FUNCTION
}

\begin{abstract}
We wished to investigate the prevalence and extent of lower urinary tract disorders including urinary incontinence. Since no validated questionnaire was available in Dutch, we decided to develop one ourselves. Since lower urinary tract disorders are still a taboo problem, it was decided to use a written, self-administered questionnaire. The use of such a questionnaire gives patients the necessary anonymity. The questionnaire had to be reproducible, valid and applicable to a population of inhabitants of homes for the elderly. Therefore, it had to be simple and easy to answer, if necessary together with the nursing staff or relatives.

First, a draft questionnaire was generated with help from experts and the literature. Between the first draft and the final questionnaire many alterations were made, as questions that seemed relevant at first were found to be difficult to understand by the respondent or lead to superfluous information. Agreements between the questionnaire, the urologist's medical history and the urological workup were assessed by means ol kappa testing. The agreement between the final questionnaire and the urologist's classification was $72 \%$, kappa was 0.66 , while that between the final questionnaire and the complete urological workup was $69 \%$, kappa was 0.67 . The questionnaire was not very reliable in cases of infravesical obstruction. Reproducibility was tested by evaluating 37 questionnaires which were answered by inhabitants of homes for the elderly twice with an interval of two weeks. The final questionnaire consisted of questions which were reproducible, easy to understand, and applicable to an elderly, fairly independent population.
\end{abstract}

\footnotetext{
A. Remmers, F.S.C. van Waalwijk van Doom, R.A. Janknegt

Department of Urology, University Hospital Maastricht. The Netherlands
}

submitted for publication 



\section{INTRODUCTION}

In epidemiological surveys a questionnaire is an important tool for establishing the existence and prevalence of diseases in the population. The questionnaire can be mailed (the respondent completes the questions himself), or administered by an interviewer who records the answers, or a combination of the two methods. One of the most important advantages of mailed questionnaires is that they are a quick and safe tool for gathering data. Furthermore, data about sensitive items can be gathered anonymously. Disadvantages might be a low response rate and/or inadequate or unreliable answers. A mailed questionnaire is generally used to predict and evaluate health, while interviewer-administered questionnaires are used to determine how individuals or groups differ with respect to certain traits or variables.'

We wanted to develop a questionnaire to establish the prevalence of lower urinary tract symptoms with a special emphasis on incontinence, among inhabitants of homes for the elderly. That is, a population of fairly independent elderly people, who need help in housekeeping, shopping, and sometimes also in one or more personal care tasks (ADL). Lower urinary tract problems are an issue which, especially among elderly people, carries a taboo. Therefore, we wanted the questionnaire to be anonymous and easy to answer.

In case of lower urinary tract complaints, medical history is an important tool in deciding on the type of lower urinary tract disorder. The value of medical history has been investigated and described in the literature. Lagro-Janssen ${ }^{2}$ investigated the value of medical history in diagnosing urinary incontinence in women in general practice. It was concluded that urodynamics are unnecessary in most women presenting, with urinary incontinence. Symptoms of stress incontinence in the absence of symptoms of urge incontinence had a sensitivity of $78 \%$, a specificity of $84 \%$ and a predictive value of $87 \%$. Symptoms of urge incontinence in the absence of symptoms of stress incontinence excluded genuine stress incontinence. The urodynamic diagnosis was used as the standard to decide on the type of incontinence. In a population of outpatients, Sand ${ }^{3}$ compared medical history with urodynamic diagnosis, and found that a history of stress incontinence had a sensitivity of $100 \%$ and a specificity of $65.2 \%$. If there was a history of urgency and/or urge incontinence, all subjects showed detrusor instability dering urodynamics. In cases with combined symptoms $(\mathrm{N}=132), 89$ had stress incontinence only, 13 motor urge incontinence only, and 30 mixed incontinence. Bergman ${ }^{4}$ found that the symptom of 'involuntary loss of urine during coughing/sneezing' had a sensitivity of $90 \%$, a specificity of $24 \%$, and a positive predictive value of $79 \%$. For the symptom of 'involuntary loss of urine before reaching the toilet' these figures were $67 \%, 87 \%$, and $17 \%$ respectively. They also used the urodynamic diagnosis as a standard.

The figures indicate that medical history is an important tool in diagnosing the type of incontinence.

The questionnaire to be developed had to meet certain demands ${ }^{1,5,6}$ :

- cover the domain of interest, that is lower urinary tract disorders (content validity);

- have a professional appearance (face validity); 
- have an acceptable agreement with respect to the final diagnosis and the medical history or medical history classication by the urologist (criterion validity);

- reproducible;

- applicable in an elderly population that is dependent on others for one or more household activities and sometimes for personal care tasks;

- easy to understand and to answer with some help from the nursing staff and/or relatives; and

- applicable as an anonymous written questionnaire.

\section{MATERIALS \& METHODS}

Content validity. A literature survey and expert knowledge were used to formulate questions to cover the domain of lower urinary tract disorders. Most questions were yes/no questions or multiple choice. This draft questionnaire was then used by nurses of the urodynamic unit and by the investigator to question patients who had been referred to the urological department for evaluation of their lower urinary tract dysfunction. Questions were reformulated or deleted if the patient or the interviewer regarded them as unclear or ambiguous. If the patient or the interviewer had the feeling that some topics were missing, new questions or answers were formulated.

Face validity. In order to make the questionnaire user-friendly and feasible, it was typed on a personal computer with a wordprocessing program and printed on a laser printer. Every item was numbered and room was left to mark or write down the answer.

Criterion validity regarding the symptom of incontinence. This was tested among 40 inhabitants of a home for the elderly by asking the nurse whether the inhabitant was incontinent, and the inhabitant 'Do you sometimes or more frequently lose urine involuntarily?', and if yes, 'Does it occur daily?' The nurses' observation was compared with the inhabitant's answer on both questions. Agreement, kappa value, sensitivity and specificity were calculated.

Criterion validity regarding medical history classification. This was tested in a population of 29 (20 female and 9 male) randomly selected outpatients of our urological department with urinary incontinence and/or other lower urinary tract disorders, who were scheduled for a urodynamic investigation and who completed the questionnaire. The mean age in this test group was 51 , range $20-81$. The medical history classification could be derived from the answers to special questions (see table 6). The result of the questionnaire was compared with the urologist's medical history classification and with the result of a full urological workup. For statistical analysis kappa testing was used, calculating inter-observer agreement above agreement by chance. The urological workup consisted of all investigations used to establish a final diagnosis, i.e., the diagnosis on which therapy is based. The urodynamic investigation, which was performed in accordance with ICS standards ${ }^{7}$ constituted a 
substantial part of this. It included initial uroflowmetry, urethral pressure profilometry (sensor in the 12 o'clock position, withdrawal rate $0.5 \mathrm{~mm} / \mathrm{sec}$ ), filling cystometry ( $35 \mathrm{ml}$ per minute with the patient in sitting position) and a pressure-flow study. The filling phase was stopped when the patient indicated a strong desire to void. A 9F Gaeltec catheter with one sensor at the tip to measure bladder pressure and 3 sensors $5-7 \mathrm{~cm}$ from the tip to measure urethral activity was used transurethrally, with the sensors in the 12 o'clock position. A $5 \mathrm{~F}$ Gaeltec catheter was used rectally to measure abdominal pressure.

Table 6. Deciding on type of lower urinary tract disorder. In deciding on urge or mixed incontinence, it is not necessary that the questions numbered 1,2 and 3 should be answered abnormal. In deciding on outflow problems it is not necessary that questions 7 and 8 should be answered abnormal.

$\mathrm{si}=$ stress incontinence; ui=urge incontinence; $\mathrm{mi}=$ mixed incontinence; en=nocturnal enuresis; op=outflow problems; ur/fr=urgency/frequency

\begin{tabular}{|c|c|c|c|c|c|c|}
\hline question & si & ui & $m i$ & $\begin{array}{c}\text { only } \\
\text { en }\end{array}$ & $\begin{array}{l}\text { only } \\
\text { op }\end{array}$ & $\begin{array}{l}\text { only } \\
\text { urifr }\end{array}$ \\
\hline $\begin{array}{l}\text { 1. Do you sometimes or more frequently } \\
\text { lose urine involuntarily? }\end{array}$ & yes & yes & yes & yes & no & no \\
\hline $\begin{array}{l}\text { 2. Do you have to rush in order to reach } \\
\text { the toilet in time? }\end{array}$ & no & yes & yes & no & no & yes \\
\hline $\begin{array}{l}\text { 3. Do you experience strong urge } \\
\text { sensations between voidings? }\end{array}$ & no & yes & $\begin{array}{l}\text { yes } \\
\text { or no }\end{array}$ & no & no & yes \\
\hline $\begin{array}{l}\text { 4. Do you (sometimes) lose urine on the } \\
\text { way to the toilet? }\end{array}$ & no & yes & yes & no & no & no \\
\hline 5. Do you lose urine while coughing? & yes & no & yes & no & no & no \\
\hline 6. Do you lose urine only at night? & no & no & no & yes & no & no \\
\hline 7. Are you able to void with a good flow? & $\begin{array}{l}\text { yes } \\
\text { or no }\end{array}$ & $\begin{array}{l}\text { yes } \\
\text { or no }\end{array}$ & $\begin{array}{l}\text { yes } \\
\text { or no }\end{array}$ & no & no & yes \\
\hline 8. Do you need to strain to pass urine? & $\begin{array}{l}\text { yes } \\
\text { or no }\end{array}$ & $\begin{array}{l}\text { yes } \\
\text { or no }\end{array}$ & $\begin{array}{l}\text { yes } \\
\text { or no }\end{array}$ & no & yes & no \\
\hline
\end{tabular}

Reproducibility. The reproducibility of each question was assessed by means of a test-retest analysis: inhabitants of a home for the elderly were asked to answer the questions twice, with a time interval of two weeks. All interviews were made by the same investigator. 


\section{RESULTS}

Content validity. Circa one hundred outpatients were interviewed by using the questionnaire. Many alterations were made and a second draft questionnaire was assembled and once again submitted to the experts for comment. Only some minor changes were necessary before everyone agreed on the final questionnaire. It consisted of 64 items: 9 on demographic data, 8 on incontinence in general (use of diapers, severeness and frequency of the incontinence, etc.), 7 on type of incontinence (stress, urge, mixed, other), 16 on other lower urinary tract symptoms, 15 on factors with a possible relation to incontinence (mobility, lower abdominal operations, etc.) and 9 on the burden of incontinence and applications for medical help.

Criterion validity regarding the symptom of incontinence. Tables $7 \mathrm{a}$ and $7 \mathrm{~b}$ show the results. When residents were asked 'Do you sometimes or more frequently lose urine involuntarily' (see table 7a), the agreement between the nurses' observations and the inhabitants' answer was $70 \%$, the kappa value was 0.38 . Sensitivity was $100 \%$, specificity $64 \%$, using the nurses' observations as gold standard. When residents indicated that they lose urine daily (see table $7 \mathrm{~b}$ ), the agreement was $93 \%$, kappa 0.75 sensitivity $86 \%$, specificity $94 \%$.

Table 7a. Criterion validity regarding the symptom of incontinence, tested among inhabitants of a home for the elderly.

\begin{tabular}{llcc|c} 
& & \multicolumn{3}{c}{ nurses } \\
& & yes & no & total \\
inhabitants & 7 & 12 & 19 \\
\cline { 2 - 5 } & no & 0 & 21 & 21 \\
\cline { 2 - 5 } & total & 7 & 33 & 40
\end{tabular}

Table $7 \mathrm{~b}$. Criterion validity regarding the symptom of daily incontinence, tested among inhabitants of a home for the elderly.

\begin{tabular}{clcc|c} 
& & \multicolumn{3}{c}{ nurses } \\
& & yes & no & total \\
inhabitants & yes & 6 & 2 & 8 \\
& no & 1 & 31 & 32 \\
\cline { 2 - 5 } & total & 7 & 33 & 40
\end{tabular}

Criterion validity regarding medical history classification. Table 8 shows the results of classifications by the questionnaire, the urologist, and the complete urological workup respectively. Table 9 shows the level of agreement between the classification methods. The agreement between the medical history classification derived from the questionnaire and the urologists' medical history classification was $72 \%$, that between medical history classification from the questionnaire and the complete urological workup was $69 \%$. The agreement between the urologists' medical history 
classification and the complete urological workup was $83 \%$. Kappa values were, respectively, $0.66,0.67$ and 0.86 .

Table 8. Results derived from the questionnaire, the medical dossier and the complete urological workup in a population of outpatients from our urological department.

\begin{tabular}{lccc} 
result & $\begin{array}{c}\text { classification by } \\
\text { questionnaire }\end{array}$ & $\begin{array}{c}\text { classification by } \\
\text { urologist }\end{array}$ & $\begin{array}{c}\text { final } \\
\text { diagnosis }\end{array}$ \\
\hline stress incontinence & 1 & 5 & 3 \\
urge incontinence & 9 & 9 & 9 \\
mixed incontinence & 9 & 3 & 5 \\
nocturnal enuresis & 3 & 3 & 3 \\
urgency/frequency & 4 & 4 & 1 \\
outflow problems & 3 & 5 & 6 \\
hypotone detrusor & 0 & 0 & 1 \\
normal & 0 & 0 & 1 \\
\hline total & 29 & 29 & 29
\end{tabular}

Table 9. Correlation between the result from the questionnaire, the medical dossier, and the complete urological workup in a population of outpatients from our urological department.

\begin{tabular}{lccc} 
result & $\begin{array}{c}\text { classified the same } \\
\text { by questionnaire } \\
\text { and urologist }\end{array}$ & $\begin{array}{c}\text { classified the same } \\
\text { by questionnaire } \\
\text { and urological } \\
\text { workup }\end{array}$ & $\begin{array}{c}\text { classified the same } \\
\text { by urologist and } \\
\text { urological workup }\end{array}$ \\
\hline stress incontinence & 1 & 1 & 3 \\
urge incontinence & 8 & 8 & 9 \\
mixed incontinence & 3 & 4 & 3 \\
nocturnal enuresis & 3 & 3 & 3 \\
urgency/frequency & 3 & 1 & 1 \\
outflow problems & 3 & 3 & 5 \\
\hline total & $21(72 \%)$ & $20(69 \%)$ & $24(83 \%)$
\end{tabular}


Reproducibility. Of the 47 inhabitants who were asked to answer the questionnaire twice, 6 were mentally disabled in such a way that they could not understand the questions and/or gave unreliable answers. One inhabitant refused to answer both questionnaires and 3 refused to answer the second questionnaire. The 37 remaining questionnaires could be analysed. The mean age in this test group was 84 (range 7298 ) in the total group, 85 (72-98) for the females and 81 (72-91) for the males. Fron the original questionnaire, 20 questions needed some extra explaining and/or led to different answers from the same respondent. After a close look at these questions they were removed because they were irrelevant or gave superfluous information.

Of the original questionnaire 43 questions remained: 6 on demographic data, 5 on incontinence in general (use of appliances, amounts of urine lost, etc.), 4 on type of incontinence (stress, urge, mixed, other), 12 on other lower urinary tract symptoms, 7 on factors with a possible relation to incontinence (mobility, lower abdominal operations, etc.) and 9 on the burden of incontinence and applications for medical help. The final questionnaire is presented in appendix A.

\section{DISCUSSION}

When using a clinical test to establish a diagnosis, validation and reproducibility testing is necessary, if not obligatory, to ascertain that results agree with reality. This is also applicable to the use of a questionnaire as a method of data collection.

Expert knowledge (urologists) and the literature concerning questionnaires about lower urinary tract disorders were used to formulate questions and integrate them into the questionnaire to cover the domain of interest. Most questions were yes/no or multiple choice questions, which makes the questions easy to understand and data handling more convenient, especially if the aim is to construct a database for statistical analysis.

Kappa is, in this case, a measure of inter-observer agreement, that is, a measure of agreement between observers, taking into account predictable chance concurrency. Considering agreement in continence status between the nurses' observation and the inhabitants answer, kappa is rather low ( 0.38 , that is only $38 \%$ above the expected by chance agreement) in cases where an inhabitant is asked about incontinence, regardless of frequency or amount. It is good $(0.75)$ in case of daily incontinence. This is probably because nurses are unaware of occasional incontinence, e.g. when an inhabitant once loses some urine while coughing or lifting a heavy object with a full bladder.

The agreement between the questionnaire and the final diagnosis regarding lower urinary tract disorders in the population of outpatients was $72 \%$. Although number of patients is small $(n=29)$, the result was in agreement with an earlier study performed among 100 outpatients: $67 \%$ agreement between the questionnaire's classification and the urological workup. ${ }^{8}$ Kappa testing revealed that $66 \%$ of the conclusions by questionnaire and urologist, scored above predictable chance concurrency. For agreements between questionnaire and urological workup this figure was $67 \%$. 
Medical history taking is not always a reliable tool for establishing a diagnosis, although it is an important tool. A problem diagnosis was infravesical obstruction in combination with urgency/frequency or even urge incontinence. The questionnaire diagnosed these patients as urgency/frequency and urge incontinent respectively. For reproducibility testing, interviews were made by the investigator. Although this introduces a bias, it was chosen to do so in order to be able to reformulate answers and questions consistently and implement them in the final questionnaire. When inhabitants of homes for the elderly were confronted with the questionnaire, only 1 $(2 \%)$ inhabitant refused to answer the questions. Most seemed happy with the interest taken in them. Some questions were difficult to understand and needed some explanation. These questions were removed, since in the near future the questionnaire will be used without an interviewer who can explain the questions. Other questions seemed irrelevant or lead to superfluous information. An example was a question about drinking habits: many of these elderly people could not indicate the amount of fluid they drank during one day, and furthermore, they only drank small quantities. The question was originally incorporated since the more one drinks, the more frequently one can be expected to visit the toilet for voiding. The results illustrate that it is necessary to test a questionnaire among those who have to answer it.

\section{CONCLUSIONS}

Between the first draft and the final questionnaire, many alterations were made. Questions that seemed relevant at first were found to be difficult to understand by the respondent or lead to superfluous information.

The questionnaire's agreement with the final diagnosis after a complete urological workup is acceptable (kappa $=0.66)$.

The questionnaire is not very reliable in cases of infravesical obstruction: only 3 from the 7 patients with this problem were diagnosed by means of the questionnaire. Diagnosis of patients with poor flow and/or straining during voiding should be reconsidered or regarded with a certain degree of reservation.

The final questionnaire consists of questions which are reproducible, easy to understand, and applicable in an elderly, fairly independent population. 


\section{REFERENCES}

1. Del Greco L, Walop W

Questionnaire development: 1. formulation

CMAJ 1987; 136: 583-585

2. Lagro-Janssen ALM, Debruyne FMJ, Weel C van

Value of the patient's case history in diagnosing urinary incontinence in general practice

Br J Urol 1991; 67: 569-572

3. Sand PK, Hill RC, Ostergard DR

Incontinence history as a predictor of detrusor instability

Obstetrics \& Gynecology 1988; 71: 257-259

4. Bergman A, Bader $\mathbf{K}$

Reliability of the patient's history in the diagnosis of urinary incontinence

Int J Gynecol Obstet 1990; 32: 255-259

5. Del Greco L, Walop W, McCarthy RH

Questionnaire development: 2 . validity and reliability

CMAJ 1987; 136: 699-700

6. Chisholm EM, Dombal FT de, Giles GR

Validation of a self administered questionnaire to elicit gastro-intestinal symptoms

Br Med J 1985; 290: 1795-1796

7. Abrams P, Blaivas JG, Stanton SL, et al

The standardisation of terminology of lower urinary tract function.

Scand J Urol Nephrol (suppl) 1988; 114: 5-19

8. Waalwijk van Doorn ESC van, Remmers A, Janknegt RA

Extramural ambulatory monitoring during natural filling and normal daily activities: evaluation of 100 patients

J Urol 1991; 146: 124-131 


\title{
A URINARY TRACT QUESTIONNAIRE SURVEY IN HOMES FOR THE ELDERLY
}

\begin{abstract}
This study was performed to establish to what extent urinary incontinence and other voiding disorders occur among inhabitants of homes for the elderly. Dutch investigators have reported the prevalence of urinary incontinence in elderly women living independently at home to be $23 \%$ and $31 \%$ respectively. In Dutch nursing homes about $44 \%$ of the somatic and $68 \%$ of the psychogeriatric patients are urinary incontinent. The prevalence and severity of lower urinary tract symptoms including urinary incontinence among residents of Dutch homes for the elderly is not known. The aims of this study were, firstly, to estimate the prevalence and severity of urinary incontinence and, secondly, to estimate the prevalence of different types of urinary incontinence and other lower urinary tract disorders. The third aim was to evaluate anomalies often associated with incontinence and the fourth to evaluate the burden on the patient resulting from incontinence. Inhabitants $(\mathrm{N}=520)$ of 7 homes for the elderly were asked to participate in a written questionnaire survey about lower urinary tract symptoms. The response rate was $79 \% ; 100$ male and 308 female residents. The mean age was 83 (range 56-102). Incontinence, defined as involuntary loss of urine on a daily basis, occurred in $17 \%$ of the males and $31 \%$ of the females. Of the incontinent subjects, $60 \%$ consulted a physician for incontinence, although only $34 \%$ experienced the incontinence as a complaint. Urinary incontinence was not clearly related to age in this group of very old subjects. Recurrent cystitis, imminent voiding, strain voiding, cerebro-vascular accident, and poor mobility all seem to be related to incontinence in the total population. In males this was also true for reported weak stream, faecal incontinence, and Parkinson's disease; in females also with nocturia and childbirth.
\end{abstract}

A. Remmers E.S.C. van Waalwijk van Doom, R.A. Janknegt

Department of Urology, University Hospital Maastricht. The Netherlands

submitted for publication 
(4)

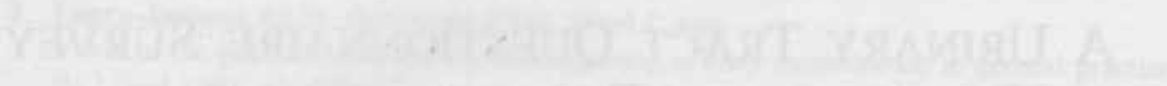

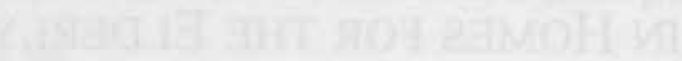

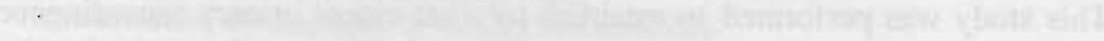

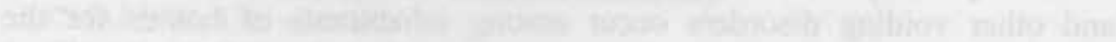

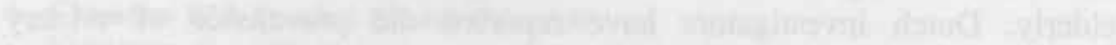
15.

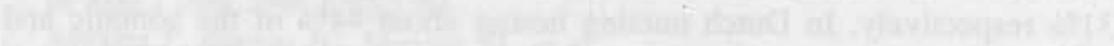

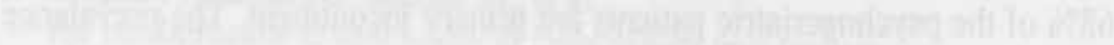

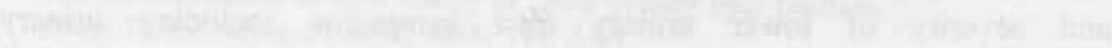

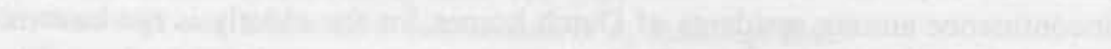

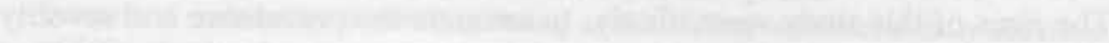

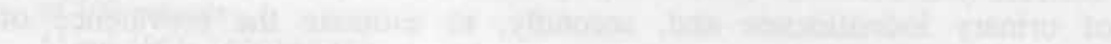

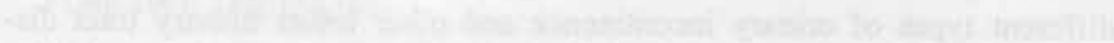

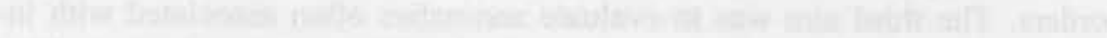

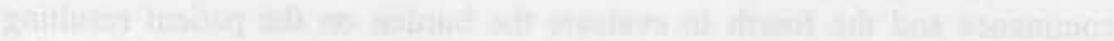
3.

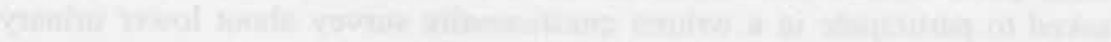

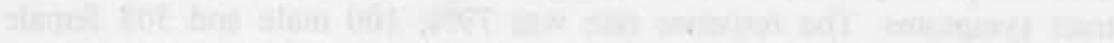
10:

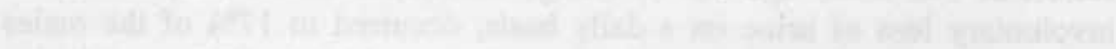

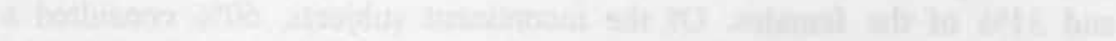

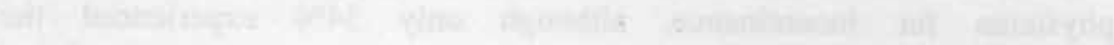

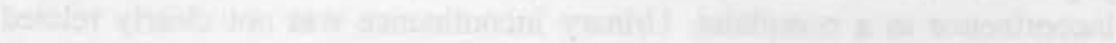
Th

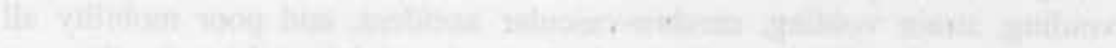
The The

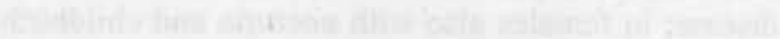




\section{INTRODUCTION}

Many surveys have been performed to establish the prevalence of urinary incontinence among elderly people. The results of these studies show considerable variation, ${ }^{1,2}$ differences in definition of urinary incontinence, study population, and methods of data collection. The International Continence Society Standardisation Committee recommends to define urinary incontinence as involuntary loss of urine which is objectively demonstrable and a social or hygienic problem, ${ }^{3}$ but this definition can often not be used in prevalence surveys. A review of the international literature showed that incontinence probably occurs in $20-25 \%$ of the females aged 60-65 and over who live indepently at home and in around $15 \%$ of the males.

Little is known about the prevalence and severeness of urinary incontinence in the Netherlands. Kok ${ }^{4}$ reported on the prevalence of urinary incontinence in elderly females living independently at home, she found that urinary incontinence occurred in $23 \%$. Van Eijndhoven ${ }^{5}$ did the same in females aged 25 and over: $31 \%$ of the females aged 65 and over were found to suffer from the condition. In Dutch nursing homes about $44 \%$ of the somatic and $68 \%$ of the psychogeriatric patients are troubled by urinary incontinence (source: SIVIS).

The present study was undertaken to establish the prevalence and severeness of urinary incontinence, as well as the prevalence of types of incontinence and voiding disorders in elderly male and female residents of homes for the elderly, by means of a written questionnaire. Abnormalities often associated with incontinence and the burden of incontinence were also evaluated. Results have been compared with the literature.

\section{MATERIALS \& METHODS}

To establish the prevalence of urinary incontinence, it was decided to use a written questionnaire delivered by the nursing staff. If necessary, nurses could offer help, in order to improve consistency and reliability. Residents could answer the questions in private and anonymously, to make the overall results more reliable.

A classification regarding incontinence and voiding disorders could be derived from the questionnaire. For this purpose ICS standards ${ }^{3}$ were used as much as possible. Table 10 shows questions and answers used to decide on type of incontinence. Table 11 shows the definitions used for each of the lower urinary tract symptoms. The questionnaire has been tested on reproducibility and validity regarding continence status and the diagnosis of type of incontinence. ${ }^{4}$

Residents $(\mathrm{N}=520)$ of 7 homes for the elderly were asked to answer the questionnaire. The residents approached were in general self-supporting as regards activities of daily life, they only needed some help in housekeeping, shopping and sometimes in one or two personal care tasks. 
Incontinence was defined as daily involuntary loss of urine. The severeness of incontinence was evaluated in two different ways: in terms of amount of urine loss (drops, dashes or massive) and in terms of use of appliances (yes or no).

Statistical testing of prevalence differences in subgroups, was done using the Chisquare test for independent proportions, unless specified otherwise.

Table 10. Deciding on type of incontinence. In deciding on urge or mixed incontinence, it is not necessary that both questions numbered 1 and 2 should be answered positively.

si=stress incontinence; ui=urge incontinence; $m i=$ mixed incontinence; en=nocturnal enuresis; uncl=unclassified incontinence; ?=do not know.

\begin{tabular}{lccccc} 
question & si & ui & mi & on & uncl \\
\hline 1. Do you have to rush in order to reach the toilet in time? & no & yes & yes & no & $?$ \\
\hline 2. Do you (sometimes) lose urine on the way to the toilet? & no & yes & yes & no & $?$ \\
\hline 3. Do you lose urine while coughing? & yes & no & yes & no & $?$ \\
\hline 4. Do you lose urine only at night? & no & no & no & yes & $?$
\end{tabular}

Table 11. Lower urinary tract symptoms and their definitions.

\begin{tabular}{ll} 
symptom & definition \\
\hline imminent voiding & $\begin{array}{l}\text { urge which makes it necessary to rush to the toilet, to prevent } \\
\text { incontinence }\end{array}$ \\
\hline noeturia & two or more voidings at night \\
\hline recurrent cystitis & $\begin{array}{l}\text { cystitis more than twice a year in females and more than once a year } \\
\text { in males }\end{array}$ \\
\hline weak stream & resident voids with a poor flow \\
\hline hesitancy & $\begin{array}{l}\text { resident indicates that, when on the toilet, he has to wait before the } \\
\text { flow starts }\end{array}$ \\
\hline strain voiding & resident indicates that he/she has to strain to be able to pass urine \\
\hline catheter & use of an indwelling catheter or intermittent catheterisation
\end{tabular}




\section{RESULTS}

Of the 520 questionnaires distributed, 408 were (partially) completed and returned, 100 by men and 308 by women. The overall response rate was $78 \%$. In $71 \%$ the questions were answered with help from others (nursing staff, relatives). The mean age was 83 (range 56-102); 81 (56-95) in males and 84 (57-102) in females. Figure 1 shows the age distribution for male and female residents.

\section{Incontinence}

The prevalence of daily urinary incontinence was $17 \%$ in males and $31 \%$ in females. Female residents were significantly more often daily incontinent than males $(\mathrm{p}=0.01)$. Incontinence can be defined in various ways. Table 12 shows the frequency of incontinence among incontinent residents. If incontinence is defined as 'involuntary loss of urine regardless of frequency or amount', $38 \%$ of the male and $52 \%$ of the female population were urinary incontinent. Table 13 shows amounts of urine lost for incontinent males and females. If only those who lose dashes or more are regarded as urinary incontinent, regardless of frequency of incontinence, $16 \%$ of the male and $28 \%$ of the female residents were incontinent. If only those who use appliances are regarded as urinary incontinent, regardless of frequency or amount, $18 \%$ of the males and $40 \%$ of the females were incontinent.

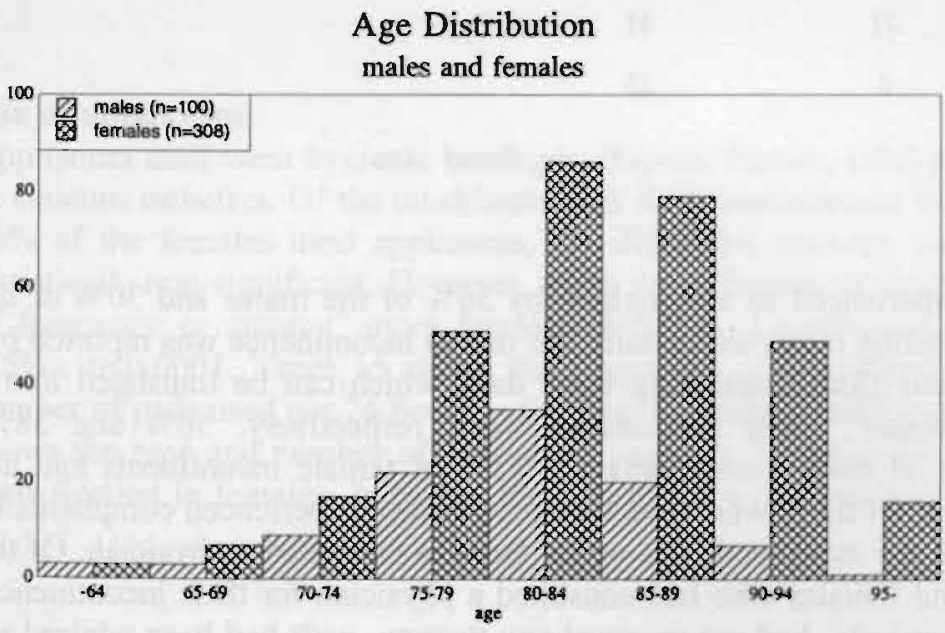

Figure 1.

Age distribution in the evaluated population, males and females separately.

Each bar represents the number of residents in the indicated age group. 
Table 12. Frequency of incontinence episodes in males and females.

\begin{tabular}{l|cc} 
frequency & $\begin{array}{c}\text { males }(n=32) \\
(\%)\end{array}$ & $\begin{array}{c}\text { females }(n=134) \\
(\%)\end{array}$ \\
\hline daily & 52 & 65 \\
2-6 per week & 25 & 9 \\
1 per week & 10 & 8 \\
3 per month & 3 & 3 \\
1-2 per month & 0 & 5 \\
$<1$ per month & 10 & 10
\end{tabular}

Table 13. Amounts of urine lost in males and females.

\begin{tabular}{l|cc} 
amount & $\begin{array}{c}\text { males }(n=32) \\
\%)\end{array}$ & $\begin{array}{c}\text { females }(n=134) \\
(\%)\end{array}$ \\
\hline drops & 63 & 35 \\
dashes & 31 & 41 \\
massive & 6 & 25
\end{tabular}

Incontinence was experienced as a complaint by $56 \%$ of the males and $30 \%$ of the females ( $p=0.04)$. Feeling restricted in daily life due to incontinence was reported by, respectively, $31 \%$ and $35 \%$. Combining these data, which can be translated into a 'burden of incontinence', these percentages were, respectively, $56 \%$ and $38 \%$. Twenty-five percent of male incontinents and $43 \%$ of female incontinents had not consulted a physician. Of those who were burdened (either experienced complaints or felt restricted), all of the males and $77 \%$ of the females consulted a physician. Of the incontinent males and females who had consulted a physician for their incontinence, $25 \%$ and $13 \%$, respectively, had not received any therapy, pads had been advised to, respectively, $8 \%$ and $19 \%$, and some kind of therapy had been given to, respectively, $58 \%$ and $68 \%$. Eight percent of the incontinent males and none of the females said they did not know whether they had received treatment. Incontinence had improved or disappeared after therapy in $43 \%$ of the males and $13 \%$ of the females. Of the patients who had not consulted a physician, none of the males and $7 \%$ of the females stated that they would like to be treated. 


\section{Types of incontinence}

Urge and stress incontinence were defined according to the ICS symptom classification. The classification 'mixed incontinence' was used when residents had both stress and urge incontinence. If neither urge or stress incontinence occurred, the classification 'other incontinence' was used. Table 14 shows the distribution of the different types of incontinence in male and female residents.

Table 14. Types of incontinence in males and females.

\begin{tabular}{l|cc} 
& males $(n=16)$ & $\begin{array}{c}\text { females }(n=87) \\
\%\end{array}$ \\
\hline stress incontinence & 6 & 13 \\
urge incontinence & 56 & 30 \\
mixed incontinence & 6 & 49 \\
only night & 0 & 3 \\
unclassified incontinence & 31 & 5
\end{tabular}

\section{Use of appliances}

Appliances used were hygienic bandages, diapers, tissues, toilet paper, handkerchiefs or condom catheters. Of the inhabitants with daily incontinence $81 \%$ of the males and $93 \%$ of the females used appliances; the difference between males and females is statistically non-significant. However, using the definition of 'incontinence regardless of frequency or amount' more females ( $84 \%$ ) used appliances compared to males $(55 \%) ; p<0.0001$. Tabel 15 shows the frequency of incontinence episodes and the number of pads used per 24 hours in the female residents with incontinence. Table 16 shows the type and number of appliances used per 24 hours for each ICS symptom classification in females. In males, the figures were too small to be presented. 


\section{CHAPTER 4}

Table 15. Pad use (number per 24 hours) in percentages related to frequency of incontinence. Males are not represented, since the number was too small.

\begin{tabular}{l|ccc} 
number of pads & $\begin{array}{c}\text { daily } \\
\%\end{array}$ & $\begin{array}{c}3 / \text { month-6/week } \\
\%\end{array}$ & $\begin{array}{c}2 \text { per month } \\
\%\end{array}$ \\
\hline 1 & 9 & 11 & 67 \\
2 or 3 & 30 & 39 & 17 \\
3 or 4 & 27 & 44 & 17 \\
5 or more & 35 & 6 & 0
\end{tabular}

Table 16. Appliances and type of incontinence in female residents. Incontinence is defined as daily urineloss.

\begin{tabular}{llcccc} 
& & $\begin{array}{c}\text { stress inc } \\
\%\end{array}$ & $\begin{array}{c}\text { urge inc } \\
\%\end{array}$ & $\begin{array}{c}\text { mixed inc } \\
\%\end{array}$ & $\begin{array}{c}\text { other inc } \\
\%\end{array}$ \\
\hline \multirow{2}{*}{ type } & sanitary towel & 33 & 40 & 18 & 14 \\
& diapers & 33 & 40 & 52 & 57 \\
& other & 33 & 20 & 30 & 29 \\
\hline number & 1 & 33 & 4 & 3 & 29 \\
per 24 & 2 or 3 & 44 & 28 & 30 & 14 \\
hours & 3 or 4 & 11 & 32 & 27 & 29 \\
& $\geq 5$ & 11 & 36 & 40 & 29 \\
\hline residents $(\mathrm{N})$ & 9 & 25 & 40 & 7
\end{tabular}

\section{Age and incontinence}

Figure 2 shows a barchart of the numbers of males and females in each age group with respect to continence status. Neither in males nor in females were differences in mean age between incontinent and continent residents statistically significant: 83 versus 80 in females and 83 versus 84 in males. 
Age Distribution Males

(in) continence $(n-93)$

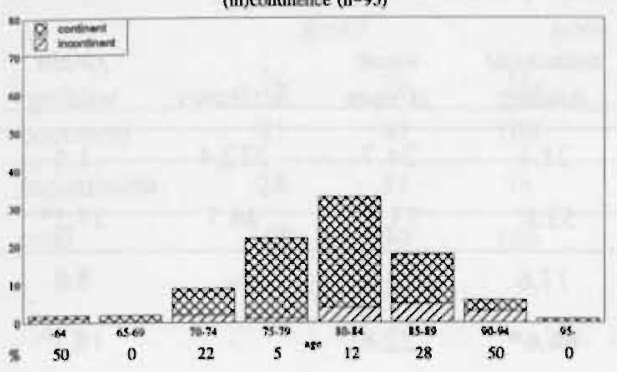

Age Distribution Females

(in) continence $(\mathrm{n}-280)$

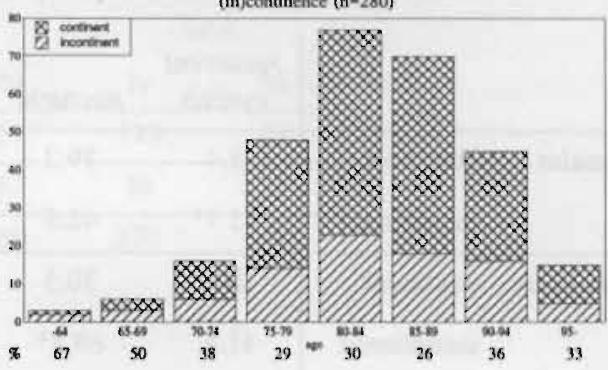

Figure 2.

Age distribution in continent and incontinent males and females

\section{Lower urinary tract symptoms and incontinence}

Table 17 shows the prevalence of lower urinary tract symptoms in male and female residents. The difference between males and females was statistically significant for recurrent cystitis. Only males were asked about hesitancy. Table 18 shows lower urinary tract symptoms in males and females seperately. In incontinent males, recurrent cystitis, imminent voiding, weak stream and strain voiding occurred significantly more often than in continent males. In incontinent females, recurrent cystitis, nocturia, imminent voiding and strain voiding occurred more often.

Only 10 residents had a catheter (2\%); 3 used clean intermittent self-catherisation and 7 had an indwelling catheter.

Table 17. Lower urinary tract symptoms in males and females. Females were not asked about hesitancy. ${ }^{*} \mathrm{p}<0.001$

\begin{tabular}{l|cc} 
symptoms & $\begin{array}{c}\text { males } \\
\%\end{array}$ & $\begin{array}{c}\text { females } \\
\%\end{array}$ \\
\hline recurrent cystitis & 9.6 & $28.3^{*}$ \\
nocturia & 37.2 & 44.8 \\
imminent voiding & 26.7 & 34.1 \\
weak stream & 30.9 & 23.4 \\
hesitancy & 33.0 & - \\
strain voiding & 7.4 & 11.6
\end{tabular}




\section{CHAPTER 4}

Table 18. Lower urinary tract symptoms in continent and incontinent males and females. Females were not asked about hesitancy. ${ }^{*} \mathrm{p}<0.001 ;{ }^{\circ} \mathrm{p}<0.01 ;{ }^{\circ} \mathrm{p}<0.05$

\begin{tabular}{ll|cccccc} 
& & $\begin{array}{c}\text { recurrent } \\
\text { cystitis }\end{array}$ & nocturia & $\begin{array}{c}\text { imminent } \\
\text { voiding }\end{array}$ & $\begin{array}{c}\text { weak } \\
\text { stream }\end{array}$ & hesitancy & $\begin{array}{c}\text { strain } \\
\text { voiding }\end{array}$ \\
\hline males & continent & 5.4 & 39.2 & 21.1 & 24.7 & 332.4 & 1.4 \\
& incontinent & $35.7^{*}$ & 42.9 & $53.8^{\circ}$ & $53.3^{\circ}$ & 46.7 & $37.5^{*}$ \\
\hline \multirow{2}{*}{ females } & continent & 24.0 & 30.5 & 17.6 & 24.0 & - & 8.8 \\
& incontinent & $41.4^{\circ}$ & $69.8^{*}$ & $64.6^{*}$ & 22.4 & - & $18.3^{\circ}$
\end{tabular}

\section{Other factors and incontinence}

Subjects were asked if they needed help in walking: possible answers were; no help needed, use of a walking aid, help needed from a third party and use of a wheelchair. Mobility was regarded as good if subjects did not need any help with walking, otherwise it was regarded as poor. Table 19 shows the results. Female residents reported poor mobility significantly more often than males $(p=0.005)$. Table 20 shows mobility and continence status in males and females separately.

Table 19. Mobility status in male and female subjects.

\begin{tabular}{lcccccc} 
& \multicolumn{2}{c}{ good } & \multicolumn{2}{c}{ poor } & \multicolumn{2}{c}{ total } \\
& $\mathrm{N}$ & $\%$ & $\mathrm{~N}$ & $\%$ & $\mathrm{~N}$ & $\%$ \\
\hline males & 50 & 57 & 38 & 43 & 88 & 24 \\
\hline females & 109 & 40 & 166 & 60 & 275 & 76 \\
\hline total & 159 & 44 & 204 & 56 & 363 & 100
\end{tabular}

Table 20a. Mobility and incontinence in males.

\begin{tabular}{lcccccc} 
& \multicolumn{2}{c}{ good } & \multicolumn{2}{c}{ poor } & \multicolumn{2}{c}{ total } \\
& $\mathrm{N}$ & $\%$ & $\mathrm{~N}$ & $\%$ & $\mathrm{~N}$ & $\%$ \\
\hline continent & 46 & 63 & 27 & 37 & 73 & 83 \\
\hline incontinent & 4 & 27 & 11 & 73 & 15 & 17 \\
\hline total & 50 & 57 & 38 & 43 & 88 & 100
\end{tabular}


Table 20b. Mobility and incontinence in females.

\begin{tabular}{lcccccc} 
& \multicolumn{2}{c}{ good } & \multicolumn{2}{c}{ poor } & \multicolumn{2}{c}{ total } \\
& $\mathrm{N}$ & $\%$ & $\mathrm{~N}$ & $\%$ & $\mathrm{~N}$ & $\%$ \\
\hline continent & 81 & 43 & 108 & 57 & 189 & 69 \\
\hline incontinent & 28 & 33 & 58 & 67 & 86 & 31 \\
\hline total & 109 & 40 & 166 & 60 & 275 & 100
\end{tabular}

Table 21 shows some other conditions that might be related to incontinence. The difference between incontinent and continent males was statistically significant with respect to reported faecal incontinence, cerebro-vascular accident and Parkinson's disease. In females, the same was true with respect to reported cerebro-vascular accident and childbirth $(\mathrm{p}=0.03)$.

Table 21. Factors with a possible relation to incontinence in continent and incontinent males and females.

cont.=continent; inc. =incontinent; $\mathrm{DM}=$ diabetes mellitus; $\mathrm{CVA}=$ cerebro-vascular accident; M Park.=Morbus Parkinson; LAO=lower abdominal operations;

* $\mathrm{p}<0.001 ;{ }^{\circ} \mathrm{p}<0.01 ;^{\circ} \mathrm{p}<0.05$

\begin{tabular}{ll|cccccccc} 
& & $\begin{array}{c}\text { hyper- } \\
\text { tension }\end{array}$ & DM & $\begin{array}{c}\text { consti- } \\
\text { pation }\end{array}$ & $\begin{array}{c}\text { faecal } \\
\text { inc. }\end{array}$ & CVA & $\begin{array}{c}M \\
\text { Park. }\end{array}$ & LAO & $\begin{array}{c}\text { diu- } \\
\text { retics }\end{array}$ \\
\hline \multirow{2}{*}{ males } & cont. & 15.6 & 10.4 & 32.5 & 2.6 & 7.8 & 5.2 & 20.0 & 45.8 \\
& inc. & 12.5 & 0 & 31.3 & $25.0^{*}$ & $31.3^{\circ}$ & $25.0^{\circ}$ & 37.5 & 50.0 \\
\hline \multirow{2}{*}{ females } & cont. & 29.0 & 15.5 & 34.2 & 7.8 & 7.8 & 5.2 & 15.5 & 58.4 \\
& inc. & 21.8 & 16.1 & 41.4 & 13.8 & $17.2^{\circ}$ & 4.6 & 19.0 & 52.9
\end{tabular}

\section{DISCUSSION}

Medical history is not a gold standard for classifying voiding disorders or type of incontinence. But it is a simple method which enables the physician to obtain a preliminary diagnosis, and especially in cases of incontinence and voiding disorders, the medical history is a very important diagnostic. 
In studies performed to investigate prevalences of incontinence, types of incontinence, and voiding disorders, it is difficult to perform a complete urodynamic workup in all subjects. Furthermore, when integrating a complete urodynamic work-up, overestimation or underestimation of prevalences can be caused by non-responders. Lower urinary tract disorders are often considered taboo, especially in elderly people. For these reasons a validated anonymous written questionnaire was used to collect data.

\section{Incontinence}

There are no standardized questionnaires on incontinence and voiding disorders; every investigator uses his own. Therefore, it is almost impossible to compare results from different prevalence studies. Furthermore, factors such as study population and sampling, data source, data collection and definition of incontinence contribute to the study outcome. Differences in these factors result in different prevalences being reported. Tables 22 and 23 summarize results regarding the prevalence of urinary incontinence reported by other investigators for three different populational settings. Table 22 reflects the situation when urinary incontinence is defined as 'involuntary loss of urine regardless of frequency or amount'. In table 23, urinary incontinence is defined more restrictively: 'involuntary loss of urine on a daily basis', ${ }^{21,23,26,28}$ 'involuntary loss of urine at least twice a week'; 'involuntary loss of urine at least three times a week', ${ }^{,, 14,25}$ 'involuntary loss of urine at least once a week', ${ }^{\prime 1}$ 'involuntary loss of urine at least twice a month; ${ }^{, 9,13,22,27}$ 'difficulty in controlling water'; ${ }^{19}$ 'loss of bladder control if unable to go to the toilet as soon as one needs to pass urine and/or urine loss while coughing or sneezing ${ }^{20}$ or 'involuntary loss of urine that is a social or hygienic problem and is objectively demonstrable'. ${ }^{24}$ The table shows that prevalences differ, even when corrected for the type of population studied and the definition used.

The results of the present study are probably best compared with the population in the study by Noelker ${ }^{16}$ since she also investigated fairly independent elderly subjects who needed help with one or more personal care tasks. The prevalence of urinary incontinence in the two populations is almost equal (see table 22). If we look only at elderly people living completely independently, the prevalence of urinary incontinence is lower. A reason for this might be that urinary incontinence often plays an important role in the decision to institutionalize patients in a nursing home $\mathrm{e}^{32}$ or home for the elderly.

It is surprising to find that $60 \%$ of the incontinent residents had consulted a physician for their daily incontinence, while only $41 \%$ felt burdened. Probably they were urged by nurses or family to visit their physician. The reason that relatively few elderly people feel burdened and that only a few of those who had not consulted a physician would like to be treated $(7 \%)$, might be explained by the belief that urinary incontinence is an inevitable aspect of old age. Males felt burdened more often and visited a physician more often than females. Perhaps females accept incontinence more as a part of old age. Noelker ${ }^{16}$ did not investigate the subjects' burden of incontinence so, comparisons with literature cannot be made.

Since $34 \%$ of the incontinent residents ( $42 \%$ males and $32 \%$ females) who visited a physician were not treated for their incontinence, it is meaningful to investigate 
whether these patients can be helped with an adequate diagnostic and therapeutic intervention. Especially since costs of urinary incontinence are high.

Table 22. Prevalence estimates (in percentages) of urinary incontinence in elderly people, using 'involuntary loss of urine regardless of frequency or amount' to define urinary incontinence.

\begin{tabular}{|c|c|c|c|c|}
\hline & \multirow[b]{2}{*}{ author(s) } & \multicolumn{3}{|c|}{$\begin{array}{l}\text { prevalence in } \% \\
\text { 'any involuntary loss' }\end{array}$} \\
\hline & & all & males & females \\
\hline \multirow{7}{*}{$\begin{array}{l}\text { studies } \\
\text { in } \\
\text { both } \\
\text { community } \\
\text { settings } \\
\text { and } \\
\text { institutions }\end{array}$} & Britton $^{7}$ & & 27 & \\
\hline & Campbell $^{8}$ & 11.6 & & \\
\hline & Milne $^{20}$ & 34.5 & 25 & 42 \\
\hline & Thomas $^{9}$ & 21.5 & 15.3 & 25.8 \\
\hline & Vehkalahtit ${ }^{10}$ & 40.6 & 38.2 & 41.3 \\
\hline & Yarnell $^{12}$ & 14 & 11 & 17 \\
\hline & Yarnell $^{11}$ & & & 49 \\
\hline \multirow{4}{*}{$\begin{array}{l}\text { studies } \\
\text { in } \\
\text { community } \\
\text { settings }\end{array}$} & Holst $^{13}$ & & & 34.3 \\
\hline & Jagger $^{14}$ & 9.2 & & \\
\hline & Jolleys $^{15}$ & & & 25 \\
\hline & Noelker $^{16}$ & 53 & & \\
\hline \multirow{3}{*}{$\begin{array}{l}\text { studies in } \\
\text { institutions }\end{array}$} & Ouslander $^{29}$ & & 40 & 50 \\
\hline & Ribeiro $^{18}$ & 50.2 & & \\
\hline & present study & 48.8 & 38.0 & 52.3 \\
\hline
\end{tabular}


Table 23. Prevalence estimates (in percentages) of urinary incontinence in elderly people, using a more restricted definition of urinary incontinence.

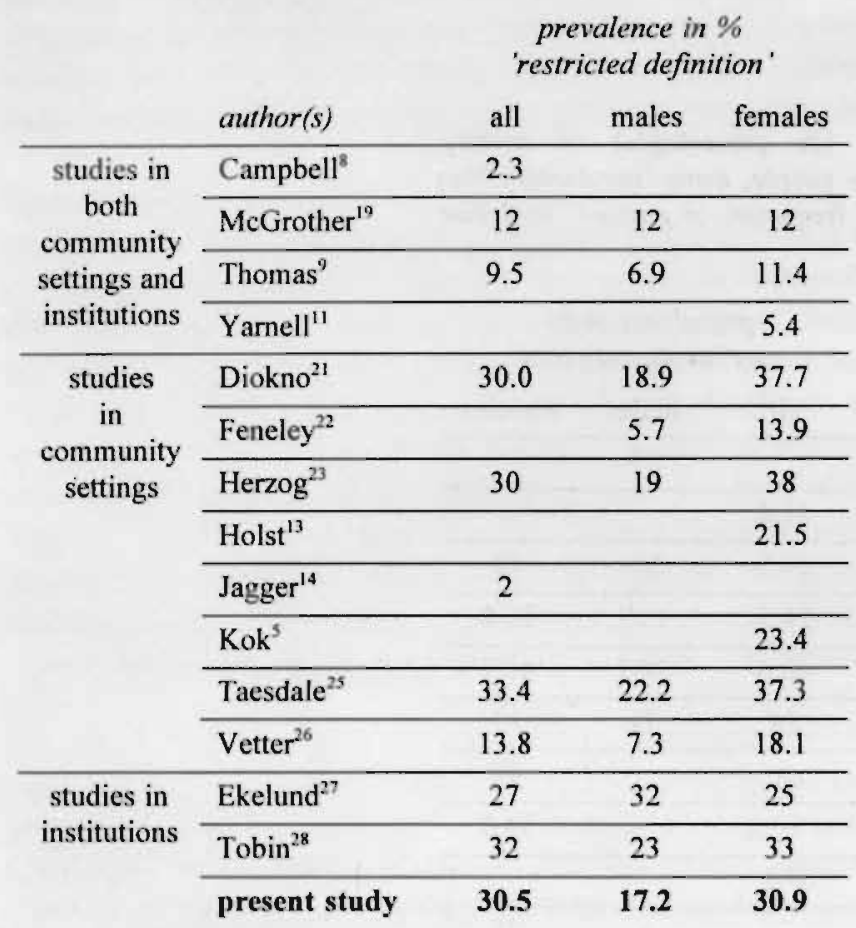

\section{Types of incontinence}

Table 14 shows the prevalence of the different types of incontinence in males and females. In men, the prevalence of urge incontinence is high. As was expected, few males are classified to have stress or mixed incontinence, they probably have an inadequate sphincter, which causes them to lose urine while coughing. In women there is a high prevalence of mixed and urge incontinence; few women have stress incontinence only. Urge incontinence seems to be more common in old age, probably due to ageing of the vascular and neuronal systems. Prevalence figures for different types of incontinence reported in the literature show considerable differences (see table 24). In the present study relatively low prevalences of stress incontinence and high prevalences of urge and mixed incontinence were found compared to the other studies mentioned in table 24 . There may be several explanations for this: it might be due to differences in definition and questions asked or to the (mean) age of the population under study and/or other populational differences. Yarnell, ${ }^{11}$ for instance, classifies everyone who does not lose urine on the way to the toilet as stress incontinent. 
Table 24. Prevalence of different types of urinary incontinence, in percentages.

\begin{tabular}{|c|c|c|c|c|c|c|c|c|}
\hline type & Campbell $^{s}$ & Yarnell" & Diokno $^{2 t}$ & Herzog ${ }^{23}$ & Holst $t^{\prime 3}$ & Milne $e^{20}$ & inc. & daily $i$. \\
\hline stress & 4.9 & 우 17.2 & $\begin{array}{lr}0 & 1.5 \\
& 1.5 \\
+ & 10.1\end{array}$ & $\begin{array}{rr}0 & 2 \\
0 & 10\end{array}$ & $\uparrow 9.3$ & $\begin{array}{lr}0 & 6 \\
+ & 31\end{array}$ & $\begin{array}{ll}0 & 1.0 \\
\text { o } & 7.7\end{array}$ & 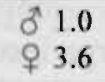 \\
\hline urge & 0.9 & q 13.3 & $\begin{array}{ll}0 & 6.6 \\
0 & 3.4\end{array}$ & $\begin{array}{ll}8 & 7 \\
0 & 4\end{array}$ & 우 16.6 & 20 & \begin{tabular}{ll}
\multirow{2}{*}{} & 15.0 \\
ㅇ & 13.2
\end{tabular} & $\begin{array}{r}89.0 \\
08.4\end{array}$ \\
\hline mixed & - & q 18.9 & $\begin{array}{lr}\delta & 5.5 \\
& 51.0 \\
+ & 21.0\end{array}$ & $\begin{array}{lr}0 & 5 \\
9 & 21\end{array}$ & 우 10.5 & - & $\begin{array}{rr}0 & 2.0 \\
0 & 19.7\end{array}$ & $\begin{array}{l}0 \\
01.0 \\
+\quad 14.0\end{array}$ \\
\hline other & 5.7 & - & $\begin{array}{ll}\delta & 5.3 \\
0 & 3.3\end{array}$ & $\begin{array}{ll}0 & 5 \\
0 & 3\end{array}$ & - & - & $\begin{array}{ll}0 & 20.0 \\
\text { o } & 11.6\end{array}$ & $\begin{array}{l}\text { o } 5.0 \\
\text { ㅇ } 2.3\end{array}$ \\
\hline total & 11.6 & 우 49.4 & $\begin{array}{ll}\text { o } & 18.9 \\
\text { O } & 37.7\end{array}$ & $\begin{array}{ll} & 19 \\
0 & 38\end{array}$ & o 36.4 & $\begin{array}{ll}\text { o } & 25.1 \\
8 & 41.9\end{array}$ & $\begin{array}{l}\text { o } 38.0 \\
\text { o } 52.3\end{array}$ & $\begin{array}{ll}\text { o } 16.0 \\
\text { ㅇ } 28.3\end{array}$ \\
\hline
\end{tabular}

\section{Use of appliances}

Incontinent female residents used appliances more than males. However, this difference disappeared when we looked only at those who lost urine daily. This might be explained by the fact that females are more used to bandages and sooner have resource to appliances than males. Furthermore, hygienic bandages are not suitable for male incontinence. In cases of daily incontinence, however, even males cannot ignore wet trousers and will ask for incontinence materials.

Females with daily incontinence use higher numbers of appliances compared to those with less than daily incontinence (see table 15). If the frequency of incontinence could be reduced by means of education and offering simple diagnostic means to establish a diagnosis and start treatment, the costs of appliances might decrease. Table 16 does not show any relation between the type of incontinence and the type of appliance used, but there does seem to be a relation between the number of appliances used per 24 hours and the type of incontinence. Urge and mixed incontinent residents use more pads compared to those with stress incontinence. Little can be said about 'other incontinence', since the majority of these residents could not be classified on the basis of the questionnaire. Use of few pads in case of daily incontinence might be suggestive of stress incontinence.

\section{Age and incontinence}

In figure 2 it can be seen that numbers in the relatively younger and older age groups were small. In the male group prevalence seems to increase with increasing age, but, since the numbers were small, results might be coincidental. In females, there was no clear relationship between incontinence and age. The mean age in the investigated population of inhabitants of homes for the elderly was 83 . This advanced age group 
showed a very high prevalence of incontinence and especially urge and mixed incontinence. In addition to age (ageing of the neuronal and vascular systems), also other factors or abnormalities which have a high incidence in old age are related to incontinence: functional disorders and the dementia syndrome and/or other neurological diseases. ${ }^{16,33}$ These factors possibly contribute to the high prevalence of urge incontinence with or without a stress component.

Studies including all ages, have shown a fluctuation in the prevalence of urinary incontinence with age. $6.9,11,13,15,22$ Van Eijndhoven, ${ }^{6}$ Yarnell $^{11}$ and Thomas ${ }^{9}$ found a high prevalence of urinary incontinence in women aged 45-54 and/or after age 75 . Holst ${ }^{13}$ found a higher prevalence of urge and mixed incontinence after 65 , while the prevalence of stress incontinence fell after age 55. Jolleys ${ }^{15}$ found that incontinence tended to increase with increasing age up to age 54, but then declined. All investigators found a greater or smaller increase in the prevalence of urinary incontinence with age. In females, the 45-54 age-group shows a prevalence peak. These are women in menopause, a condition that can cause an increase in the occurrence of wet episodes. After this age the incontinence may be cured or may just disappear.

High prevalences of urinary incontinence in old age are more common in institutional settings. No differences in mean age between incontinent and continent residents was found in the present study, a finding which was supported by Noelker ${ }^{16}$ and Ekelund. ${ }^{27}$

\section{Lower urinary tract problems}

Nocturia and weak stream showed a high prevalence (see table 17). It is common knowledge that nocturia occurs more often in old age than in young age. This may have several causes: poor cardiovascular condition, use of diuretics, and perhaps a change in the day-night rhythm of vasopressin production in old age. In the population investigated in the present study, the use of diuretics was not more frequent among incontinent residents. Nocturia occurred significantly more often in incontinent compared to continent females, a difference which was not found in males. Nocturia in males is more often related to prostate enlargement than to bladder dysfunction. In females, nocturia is probably a symptom of the bladder dysfunction that also is responsible for the incontinence. The high prevalence of weak stream is possibly due to ageing of the detrusor muscle and the nervous system. In males, prostate enlargement might also play a major role. In females there was no significant difference in reported weak stream between continent and incontinent residents, while in males this difference was statistically significant. BPH might play a major role in this.

Table 25 shows prevalences of lower urinary tract symptoms reported in the literature. No conclusions can be drawn, since the studies are difficult to compare due to differences in methodology and study population. 
Table 25. Lower urinary tract symptoms in elderly people. Prevalences in percentages. p.m. dribble $=$ post voiding dribble

* dribbling incontinence, instead of post voiding dribble

\begin{tabular}{|c|c|c|c|c|c|}
\hline symptom & $\begin{array}{l}\text { Britton } \\
\text { only ठ }\end{array}$ & $\begin{array}{c}\text { Kok } \\
\text { only } \text { ? }\end{array}$ & McGrother" & Milne $e^{20}$ & $\begin{array}{c}\text { presem } \\
\text { study }\end{array}$ \\
\hline $\begin{array}{l}\text { recurrent } \\
\text { cystitis }\end{array}$ & - & - & - & $\begin{array}{ll}8 & 11 \\
9 & 33\end{array}$ & $\begin{array}{r}\delta 9.5 \\
+28.1\end{array}$ \\
\hline frequency & 32 & $\begin{array}{l}\text { inc } 23.2 \\
\text { cont } 7.4\end{array}$ & $\begin{array}{l}\delta 5.0 \\
+4.3 \\
\end{array}$ & $\begin{array}{l}033.3 \\
\text { o } 23.1 \\
\end{array}$ & $\begin{array}{l}\delta 28.7 \\
+220.9 \\
\end{array}$ \\
\hline nocturia & 25 & $\begin{array}{l}\text { inc } 18.9 \\
\text { cont } 8.6\end{array}$ & $\begin{array}{l}03.9 \\
\varnothing 3.3\end{array}$ & $\begin{array}{ll}0 & 18.6 \\
0 & 25.4\end{array}$ & $\begin{array}{l}\text { o } 35.2 \\
\text { o } 44.9\end{array}$ \\
\hline $\begin{array}{l}\text { urgencyl } \\
\text { mand. urge }\end{array}$ & 31 & - & $\begin{array}{l}\delta 3.3 \\
86.2\end{array}$ & $\begin{array}{ll}\delta & 19.4 \\
\text { o } 20.0\end{array}$ & $\begin{array}{ll}0 & 12.2 \\
\circ & 16.3\end{array}$ \\
\hline weak stream & 30 & - & - & - & $\begin{array}{l}\delta 30.9 \\
\text { \& } 23.4\end{array}$ \\
\hline hesitancy & - & - & $\begin{array}{l}\text { d } 3.0 \\
q-\end{array}$ & - & $\begin{array}{c}\delta 32.0 \\
9-\end{array}$ \\
\hline $\begin{array}{l}\text { p.m. } \\
\text { dribble }\end{array}$ & $26^{\circ}$ & - & $\begin{array}{l}\delta^{x} 2.5 \\
q-\end{array}$ & - & $\begin{array}{l}\text { ô } 45.7 \\
\text { ㅇ } 31.7\end{array}$ \\
\hline
\end{tabular}

\section{Other factors and incontinence}

In contrast to female residents, incontinent male residents had significantly more problems with mobility (table 20) than continent males. Furthermore, in females poor mobility did not occur more often in incontinent than in continent residents, unlike the situation for males $(\mathrm{p}=0.01)$. The literature shows variable results regarding incontinence and mobility status. Ouslander ${ }^{17}$ found that the majority of incontinent (nursing home) patients had severe mobility impairments. Ribeiro ${ }^{18}$ stated that incontinent subjects more often needed help in toiletting compared to continent subjects. Ekelund ${ }^{27}$ did not find any difference in the use of walking aids between continent and incontinent geriatric patients. The relation between incontinence and mobility is not clear. The belief that incontinence is caused directly by mobility problems might be incorrect. It is more likely that preexisting voiding problems (such as motor urge) are aggravated by mobility problems.

In addition to age, lower urinary tract symptoms and mobility status, other anomalies can also influence incontinence. Table 21 shows the prevalence of the conditions investigated. Hypertension was included in the questionnaire since most antihypertensic medication has an influence on the detrusor muscle, but no significant difference was found between continent and incontinent subjects. In males there was a statistically significant relation between urinary and faecal incontinence, as well as between Parkinson's disease or cerebro-vascular accident (CVA) and incontinence. In females only CVA and childbirth were significantly related to incontinence. 
Surprisingly, lower abdominal operations do not occur more frequently in incontinent females than in those who are continent. It seems that in female residents incontinence is less influenced by other problems or diseases.

Faecal impaction can cause urinary incontinence, although the mechanism is unclear. ${ }^{29,30}$ No significant difference was found between continent and incontinent subjects regarding reported constipation. Constipation in this elderly group is usually caused by lack of physical activity and by the diet, which applies to both continent and incontinent residents. Probably because of the high prevalence of constipation no relation between incontinence and constipation could be found. Lower abdominal operations had not occurred significantly more often in incontinent than continent residents, as might have been expected. Like other studies, ${ }^{7,13.15}$ the present study showed a positive relation between childbirth and incontinence. In males, anomalies appear to contribute more to incontinence than in females.

\section{CONCLUSIONS}

Incontinence regardless of frequency or amount is very common in an elderly, fairly independent population. The ageing of the neuronal and vascular systems might play a major role, since urge and mixed incontinence showed a much higher prevalence than stress incontinence in the investigated population.

Elderly people do not very often visit a physician for their incontinence, and they are not severely burdened by their (daily) incontinence. Perhaps this is caused by the belief among elderly that incontinence is a natural aspect of old age.

In general it can be said that the prevalence of urinary incontinence in women increases with increasing age, with a more pronounced increase at age 45-54, when women are menopausal. In the very old (75-80 and over) prevalence no longer increases.

Mobility, recurrent cystitis, imminent voiding, weak stream, strain voiding, nocturia, faccal incontinence, cerebro-vascular accident, Parkinson's disease and childbirth are all related to incontinence.

Comparisons with the international literature are difficult to make, since there is little agreement with regard to study population, study sampling, data source, data collection, and the definition of urinary incontinence used. Noelker's ${ }^{16}$ results, who performed a comparable study, are in agreement with the results of the present study.

Since the cost of urinary incontinence is high, the findings that incontinence is quite common among inhabitants of homes for the elderly, that $43 \%$ of the incontinent residents did not visit a physician and that $34 \%$ of those who did, did not receive any treatment, suggest that future studies should investigate whether these patients can be helped with an adequate diagnostic and therapeutic intervention. 


\section{ACKNOWLEDGMENTS}

We would like to express our gratitude towards A.B. Visschedijk MD, J.H. Hoefnagels MD, J.J.A.M. van Dongen MD and J.P.M. Jansma MD for their help in distributing the questionnaires in the homes for the elderly. Also, we would like to thank M. van Eijndhoven MD for her fruitful cooperation in formulating the questions. 


\section{REFERENCES}

1. Mohide EA

The prevalence and scope of urinary incontinence

Clin Ger Med 1986; 2: 639-655

2. Herzog AR, Fultz NH

Epidemiology of urinary incontinence: prevalence, incidence, and correlates in community populations.

Suppl Urol 1990; 36: 2-10

3. Abrams P, Blaivas JG, Stanton SL, et al

The standardisation of terminology of lower urinary tract function.

Scand J Urol Nephrol (suppl) 1988; 114: 5-19

4. Remmers A, Waalwijk van Doorn ESC van, Janknegt RA

Development of a specific questionnaire for evaluation of lower urinary tract function

Thesis A. Remmers: Urinary incontinence and voiding disorders in the elderly; towards acceptable and applicable diagnostic evaluation

5. Kok ALM, Voorhorst FJ, Halff-Butter CMC, Janssens J, Kenemans P

De prevalentie van urine-incontinentie bij oudere vrouwen

NtvG 1991; 135, 98-101

6. Eijndhoven MJA van

Prevalentie van incontinentieproblematiek in de regio Zuid-Oost Utrecht

Unpublished

7. Britton JP, Dowell AC, Whelan P

Prevalence of urinary symptoms in men aged over 60

Br J Urol 1990; 66: 175-176

8. Campbell AJ, Reinken J, McCosh L

Incontinence in the elderly: prevalence and prognosis

Age and ageing 1985; 14: 65-70

9. Thomas TM, Plymat KR, Blannin J, Meade TW

Prevalence of Urinary Incontinence

Br Med J 1980; 281, 1243-1245

10. Vehkalahti I, Kivelä S-L

Urinary Incontinence and Its Correlates in Very Old Age

Gerontology 1985: 31: 391-396

II. Yarnell JWG, Voyle GJ, Richards CJ, Stephenson TP

The prevalence and severity of urinary incontinence in women

J Epid Comm Health 1981; 35: 71-74

12. Yarnell JWG, St. Leger AS

The prevalence, severity and factors associated with urinary incontinence in a random sample of the elderly

Age and Ageing 1979; 8: 81-85

13. Holst $K$, Wilson PD

The prevalence of female urinary incontinence and reasons for not seeking treatment NZ Med J 1988; 756-758

14. Jagger C, Clarke M, Davies RA

The elderly at home: indices of disability

J Epid Comm Health 1986; 40: 139-142

15. Jolleys JV

Reported Prevalence of Urinary Incontinence in Women in a General Practice

Br Med J 1988; 296: 1300-1302 
16. Noelker LS

Incontinence in elderly cared for by family

Gerontologist 1987; 27: 194-200

17. Ouslander JG, Kane RL, Abrass IB

Urinary Incontinence in Elderly Nursing Home Patients

JAMA 1982: 248: 1194-1198

18. Ribeiro BJ, Smith SR

Evaluation of urinary catheterization and Urinary incontinence in a general nursing home population

JAGS $1985 ; 33: 479-482$

19. McGrother CW, Castleden CM, Duffin H, Clarke M

A proile of disordered micturition in the elderly at home

Age and Ageing 1987: 16: 105-110

20. Milne JS, Williamson J, Maule MM, Wallace ET

Urinary symptoms in older people

Modern Geriatrics 198-212

21. Diokno AC, Brock BM, Brown MB, Herzog RA

Prevalence of urinary incontinence in the non-institutionalized elderly

J Urol 1986; 136: 1022-1025

22. Feneley RCL, Shepherd AM, Powell PH, Blannin J

Urinary incontinence: prevalence and needs

Br J Urol 1979; 51: 493-496

23. Herzog AR, Fultz NH, Normolle DP, Brock BM, Diokno AC

Methods used to manage urinary incontinence by older adults in the community

JAGS 1989; 37: 339-347

24. Mohide EA, Pringle DM, Robertson D, Chambers LW

Prevalence of urinary incontinence in patients receiving home care services

CMAJ 1988; 139: 953-956

25. Taesdale TA, Taffet GE, Luchi RJ, Adam E

Urinary incontinence in a community-residing elderly population

JAGS 1988; 36: 600-606

26. Vetter NJ, Jones DA, Victor CA

Urinary incontinence in the elderly at home

The Lancet 1981; 1275-1277

27. Ekelund $\mathbf{P}$, Rundgren $\AA$

Urinary incontinence in the elderly with implications for hospital care consumption and social disability

Arch Gerontol Geriatr 1987; 6: 11-18

28. Tobin GW, Brocklehurst JC

The Management of Urinary Incontinence in Local Authority Residential Homes for the Elderly

Age and Ageing 1986: 15, 292-298

29. Ouslander JG

Causes, assessment, and treatment of incontinence in the elderly

Suppl Urology 1990; 36: 25-35

30. Snusted DG, Rosenthal JT

Urinary incontinence in the elderly

AFP 1985; 32: 182-196

31. Diokno AC, Brock BM, Herzog AR, Bromberg J

Medical correlates of urinary incontinence in the elderly

Urology 1990; 36: 129-138 


\section{CHAPTER 4}

32. Ouslander JG, Zarit SH, Orr NK, Muira SA

Incontinence among elderly communiıy-dwelling dementia patients; Characteristics, management, and impact on caregivers

JAGS 1990; 38: 440-445

33. Cools HJM, Bock GH de

De samenhang van ongewenst urineverlies met andere beperkingen in het functioneren NTvG 1993; 137: 1828-1830 


\title{
EXTRAMURAL AMBULATORY MONITORING IN OUTPATIENTS AGED 60 AND OVER
}

\begin{abstract}
This study is performed as a first step towards investigating the usefulness of simple diagnostics in elderly people. The applicability of extramural ambulatory monitoring, an investigational method that can be applied outside the hospital, was established in 65 consecutive outpatients aged 60 and over with lower urinary tract complaints.

The results indicated that ambulatory monitoring was subjectively well tolerated. Objectively, it was very well able to assess detrusor activity during the filling phase, when comparing its results with the clinical urodynamic diagnosis. Assessing types of incontinence by means of medical history taking was not reliable. Furthermore, a relation was found between the amount of urine lost, demonstrated by pad-testing, and the type of lower urinary tract disorder, indicating that stress incontinence leads to lower losses than urge incontinence. The results also showed that, in elderly patients who cannot come to the urodynamic laboratory, it is more appropriate to look for non-invasive techniques.
\end{abstract}

A. Remmers, E.S.C. van Waalwijk van Doom, R.A. Janknegt

Department of Urology, University Hospital Maastricht, The Netherlands

submitted for publication 


\section{INTRODUCTION}

In most urological and gynaecological practices, a complete urodynamic workup is performed to diagnose patients with lower urinary tract problems, in order to allow an adequate choice of therapeutic intervention. Among elderly people it is difficult to achieve a urodynamic workup. In an earlier study of the epidemiology of lower urinary tract problems among residents of homes for the elderly, we found that they do not always volunteer their lower urinary tract problems and many do not want any treatment, in spite of their feeling restricted in daily life and/or experiencing complaints. Other researchers ${ }^{1-4}$ have also investigated to what extent respondents feel bothered by incontinence. Kok ${ }^{1}$ reported that $65.3 \%$ of the incontinent women investigated were bothered by their incontinence in daily life. Yarnell ${ }^{2}$ found that only $9 \%$ of the incontinent women consulted a general practitioner. In a study performed by Herzog, ${ }^{3}$ only $23 \%$ of the respondents (older adults in the community) visited a physician for their incontinence; the more severe the incontinence, the more likely respondents were to have visited a physician. Holst ${ }^{4}$ reported that $35 \%$ of the women with regular incontinence (accidental wetting twice a month or more frequently) had sought medical help. Despite the fact that elderly people experience discomfort from being incontinent, most of them do not visit a physician for diagnosis and therapy. Holst ${ }^{4}$ asked incontinent elderly people for their reasons for not seeking treatment. The two most important reasons were 'incontinence not seen as abnormal' ( $82 \%)$ and 'expecting little benefit from therapy' $(10 \%)$.

In addition to social implications, incontinence also has economic implications. The costs of incontinence appliances are high and become higher every year. In 1990 the Dutch national insurance company spend 180 million guilders on pads, compared to only 40 million in 1980. Many elderly patients pay a substantial part of their pension for appliances such as hygienic bandages. Many elderly females use pads just to be 'on the safe side', i.e., just in case accidental wetting occurs. In the prevalence study mentioned above, a relation between severeness of incontinence and number of pads used was found. Inhabitants with daily incontinence use more pads compared to those with less frequent wet episodes. If, after diagnosis and therapy, the incontinence becomes less severe, it is likely that the costs on pads will decrease.

Hence, the question arises whether elderly incontinent people might be helped, provided that they are well informed, with adequate and simple diagnostic tools, which can be used outside the hospital, e.g. in a general practice.

The first step towards investigating the usefulness of simple diagnostic means in elderly people was to investigate the applicability of extramural ambulatory monitoring, an investigational method that can be applied outside the hospital in elder outpatients with lower urinary tract complaints. Van Waalwijk van Doorn ${ }^{5}$ already concluded in his thesis 'ambulatory urodynamics' that, by means of on-line monitoring, sensitivity to demonstrate incontinence improved from $39 \%$ to $76 \%$. Sensitivity to objectify abnormalities improved from $68 \%$ to $96 \%$. Furthermore, that the over-all correlation with the medical history diagnosis is higher with ambulatory monitoring than with the conventional method, particularly when an urge component 
is involved. Therefore, in the present study, the conventional investigation was not compared with ambulatory monitoring, but subjective experience and the ability to assess detrusor overactivity in elderly patients was evaluated.

\section{MATERIALS \& METHODS}

Medical records of consecutive outpatients aged 60 and over were analysed with regard to medical history, conventional urodynamics and extramural ambulatory monitoring (EAM). Patients were taken from a database consisting of patients with lower urinary tract complaints with or without incontinence, who underwent a conventional and an ambulatory investigation in our urodynamic laboratory.

Medical history. The medical history was taken by means of a computerized urological history questionnaire. After the questions had been answered, a classification of lower urinary tract disorders was derived (urge, stress, and mixed incontinence, nocturnal enuresis, other incontinence, urgency/frequency syndrome, and outflow disorders). The questionnaire had been tested for reproducibility and agreement with the urologist's classification. The agreement between the urologist's medical history and the questionnaire classification was $72 \%$, kappa was 0.66 . Where the results of the computerized questionnaire were not available, results from the medical history taken by the urologist were used, with the same criteria for classification.

Conventional urodynamic investigation. The conventional urodynamic investigation was performed in accordance with International Continence Society standards.$^{6.7}$ It included free uroflowmetry, urethral pressure profilometry (sensor in the 12 o'clock position, withdrawal rate $0.5 \mathrm{~mm} / \mathrm{sec}$ ), filling cystometry $(35-50 \mathrm{ml}$ per second with the patient in sitting position) and a pressure-flow study. The filling phase was stopped when the patient indicated a strong desire to void. An $9 \mathrm{~F}$ Gaeltec catheter with one sensor at the tip to measure bladder pressure and 3 sensors $5-7 \mathrm{~cm}$ from the tip to measure urethral activity was used transurethrally, with the sensors in the 12 o'clock position. A $5 \mathrm{~F}$ Gaeltec catheter was used rectally to measure abdominal pressure.

Extramural ambulatory monitoring (EAM). The method has been described by Van Waalwijk van Doorn. ${ }^{8.9}$ A $5 F$ Gaeltec dual sensor catheter was used transurethrally to measure bladder and urethral function; a $5 \mathrm{~F}$ Gaeltec single sensor catheter was used rectally to measure abdominal pressure. The catheters were connected to a miniaturized microprocessor controlled Holter monitor (Biolnterface). Patients were asked to keep a frequency/volume chart and note voiding (time and volume), drinking (time and volume), urge sensations, urine loss and remarks. The investigation also included pad-testing, preweighed pads were given to the patients and the used ones had to be kept in a closed plastic bag and returned at the end of the investigational period. Furthermore, patients were asked to push the monitor's event button when entering the toilet for voiding. This is of considerable importance in recognizing detrusor 
overactivity just before voiding (imminent voiding as a sign of motor urge or motor urge incontinence). After careful instruction, among others to drink $200 \mathrm{ml} / \mathrm{hr}$ in order to prevent urinary tract infection and to have at least one voiding, the patient left the hospital and resumed normal daily activities. At the end of the day the patient returned to the hospital, the system was disconnected, pads were weighed and counted, and the measurement was analysed. After analysis, variables related to bladder behaviour could be calculated: number of contractions per hour, number of voidings per hour, volume voided per voiding, volume voided per hour, and volume drunk per hour. These variables could then be put together in a model or formula that calculated the detrusor activity index (DAI). ${ }^{10}$ The DAI expresses detrusor activity during the filling phase on a scale from 0 to 1 .

Patients were classified according to the results of the investigational methods, using the ICS classification: motor urge incontinence, stress incontinence, mixed incontinence, other incontinence, motor urge, and other voiding problems. 'Other incontinence' was used as a diagnosis if a patient could not be classified to have stress and/or urge incontinence; 'other voiding problems' was used in the case of an abnormal test result in absence of bladder overactivity or incontinence.

Subjective evaluation EAM. After ambulatory monitoring, patients were asked to answer a questionnaire regarding subjective experiences from EAM. The questions are presented in table 26 . Results were compared with the results from patients aged 59 or less.

\section{RESULTS}

Sixty-seven medical records were analysed, 61 females and 6 males. The mean age in this elderly group was $68 \pm 6$, ranging from $60-84$. Two patients ( 1 male and 1 female) had to be excluded from the analysis, as they did not void during the ambulatory investigation period. This makes the investigation unreliable, since at least one voiding should be present to allow evaluation of detrusor function. For all patients, a medical history was available, allowing classification. The conventional urodynamic investigation was conclusive in all subjects. Outflow disorders did not occur in this group of patients, since these patients are not eligible for EAM. The mean duration of the EAM period was 8:07 hours (range 3:21-23:02).

Table 26 shows the results of the subjective evaluation questionnaire. Results of the conventional investigation and EAM can be combined into one clinical urodynamic diagnosis. Table 27 shows the clinical urodynamic diagnosis in each medical history category. Figures 3 and 4 show the detrusor activity index (DAI) with respect to, respectively, the medical history classification and the clinical urodynamic diagnosis. 


\section{CHAPTER 5}

Table 26. Subjective evaluation questionnaire.

\begin{tabular}{llcc} 
question & answer & elderly & younger \\
\hline Were you bothered by the catheters? & no & 70 & 49 \\
& urethral & 28 & 42 \\
& rectal & 0 & 2 \\
& both & 2 & 6 \\
\hline Did you experience more urge than usual? & no & 57 & 57 \\
& yes & 39 & 39 \\
& a lot more & 4 & 4 \\
\hline Could you void as usual? & yes & 92 & 83 \\
& no & 8 & 17 \\
\hline Did you have to void more often? & no & 52 & 55 \\
& yes & 48 & 45 \\
\hline Could you be normally active? & yes & 64 & 49 \\
& partly & 26 & 37 \\
& no & 10 & 14 \\
\hline Did you experience the investigation as too inconvenient? & no & 58 & 60 \\
& a little & 38 & 32 \\
& yes & 4 & 8
\end{tabular}

Table 27. Medical history classification versus the clinical urodynamic diagnosis.

\begin{tabular}{lccccccc}
$\begin{array}{l}\text { medical } \\
\text { history }\end{array}$ & $\begin{array}{c}\text { stress } \\
\text { inc. }\end{array}$ & $\begin{array}{c}\text { motor } \\
\text { urge inc. }\end{array}$ & $\begin{array}{c}\text { mixed } \\
\text { inc. }\end{array}$ & $\begin{array}{c}\text { motor } \\
\text { urge }\end{array}$ & $\begin{array}{c}\text { hypotonic } \\
\text { bladder }\end{array}$ & normal & total \\
\hline stress inc. & 4 & 1 & 2 & 2 & 0 & 0 & 9 \\
urge inc. & 0 & 10 & 6 & 1 & 0 & 0 & 17 \\
mixed inc. & 7 & 7 & 7 & 2 & 1 & 2 & 26 \\
other inc. & 0 & 0 & 0 & 1 & 0 & 0 & 1 \\
urgency & 0 & 4 & 0 & 6 & 0 & 1 & 11 \\
enur. noct. & 0 & 0 & 0 & 1 & 0 & 0 & 1 \\
\hline total $(\mathrm{N})$ & 11 & 22 & 15 & 13 & 1 & 3 & 65
\end{tabular}


Mean DAI for different m.h. categories

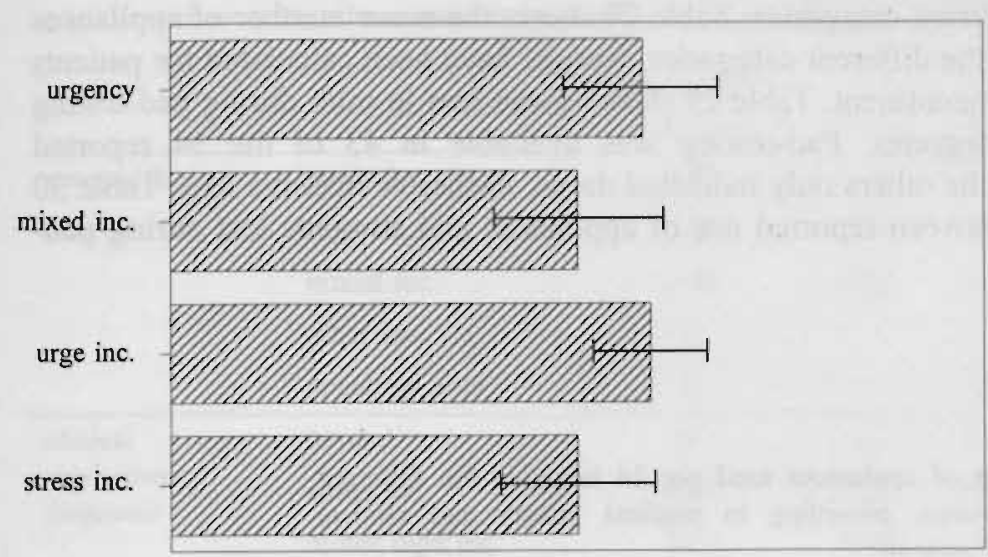

Figure 3.

Mean DAI for the different medical history categories.

$\mathrm{m} . \mathrm{h} .=$ medical history

\section{Mean DAI for different urod. categories}

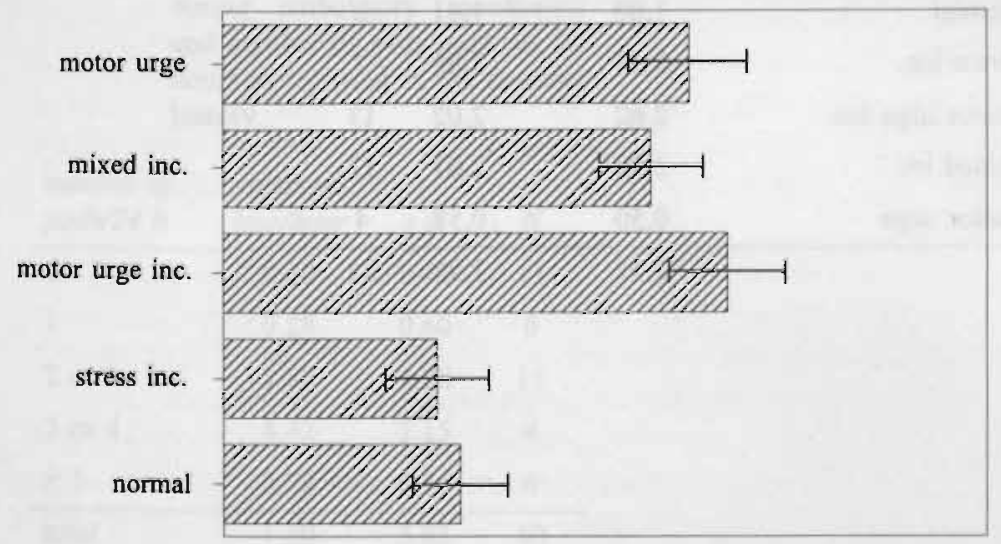

Figure 4.

Mean DAI for the different clinical urodynamic diagnosis categories.

urod.=urodynamic diagnosis 


\section{CHAPTER 5}

Correlating the use of appliances with diagnostic categories might be useful for estimating the costs of appliances if there is a significant difference in the use of appliances in the different categories. Table 28 shows the mean number of appliances used per 24 hours in the different categories. Results have been calculated for patients who reported being incontinent. Table 29 shows mean loss in $\mathrm{ml} / \mathrm{h}$ during pad-testing for the different categories. Pad-testing was available in 43 of the 54 reported incontinent patients; the others only indicated drops, dashes or massive loss. Table 30 shows the relation between reported use of appliances and amounts lost during padtesting.

Table 28. Mean number of appliances used per 24 hours in the different diagnostic groups, according to medical history and clinical urodynamic diagnosis.

\begin{tabular}{llccc} 
& & $\begin{array}{c}\text { mean number of } \\
\text { appliances/24 } \\
\text { hours }\end{array}$ & s.d. & $N$ \\
\hline medical history & stress inc. & 0.75 & 0.96 & 4 \\
& urge inc. & 3.15 & 1.99 & 13 \\
& mixed inc. & 2.25 & 1.97 & 20 \\
& nocturnal enur. & 1 & - & 1 \\
\hline clinical & normal & 1.00 & 1.41 & 2 \\
urodynamic & stress inc. & 2.43 & 1.99 & 7 \\
diagnosis & motor urge inc. & 2.62 & 2.02 & 13 \\
& mixed inc. & 2.92 & 2.07 & 12 \\
& motor urge & 0.50 & 0.58 & 4 \\
\hline total & & 2.37 & 1.98 & 38
\end{tabular}


Table 29. Pad-testing in the different diagnostic groups. For 43 of the 54 reported incontinent patients $\mathrm{ml}$ of loss during pad-testing is known; the others noted drops, dashes or massive loss.

\begin{tabular}{llccc} 
& & $\begin{array}{c}\text { mean ml } \\
\text { loss/hour }\end{array}$ & s.d. & $N$ \\
\hline medical history & stress inc. & 0.85 & 2.34 & 8 \\
& urge inc. & 1.55 & 1.44 & 12 \\
& mixed inc. & 2.40 & 4.82 & 21 \\
& other inc. & 0 & - & 1 \\
& nocturnal enur. & 0 & - & 1 \\
\hline clinical & normal & 0 & - & 2 \\
urodynamic & stress inc. & 0.47 & 0.62 & 9 \\
diagnosis & motor urge inc. & 3.52 & 4.94 & 11 \\
& mixed inc. & 2.52 & 4.23 & 13 \\
& motor urge & 0 & 0 & 7 \\
\hline total & & 1.76 & 3.61 & 43
\end{tabular}

Table 30. Volume urine lost per hour $(\mathrm{ml})$ during ambulatory monitoring and number of pads used per 24 hours as reported in the medical history.

\begin{tabular}{lccc}
$\begin{array}{l}\text { number of } \\
\text { pads } / 24 h\end{array}$ & $\begin{array}{c}\text { mean ml } \\
\text { loss/hour }\end{array}$ & s.d. & $N$ \\
\hline \hline 0 & 0.20 & 0.44 & 13 \\
1 & 0.28 & 0.60 & 6 \\
2 or 3 & 1.80 & 2.28 & 11 \\
3 or 4 & 4.42 & 7.15 & 4 \\
$\geq 5$ & 3.72 & 6.56 & 6 \\
\hline total & 1.60 & 3.65 & 40
\end{tabular}




\section{DISCUSSION}

Subjective evaluation of EAM shows that the majority of patients were not very much burdened by the investigation. About half of the patients had to void more often because they had been advised to drink $200 \mathrm{ml} / \mathrm{hr}$, which is for most patients more than usual. When comparing the results with the 'younger' patients group, EAM was better tolerated by the elderly patients.

Outflow disorders were not diagnosed, since patients with complaints of 'prostatism' are not eligible for ambulatory monitoring. In these patients it is very important to diagnose the obstruction, for which other diagnostics are available (symptom score, digital rectal examination, residual urine measurements, flowmetry, cystoscopy, pressure/flow study, etc.)

In table 27 the bold numbers indicate agreement between the medical history and the urodynamic results. The overall agreement between medical history and the clinical urodynamic diagnosis was $43 \%$. A similar study performed in 100 outpatients of all ages $^{8}$ showed agreement between medical history and urodynamics to be $67 \%$. Van Waalwijk concluded in his thesis ${ }^{10}$ that the standard urodynamic investigation is valid for demonstrating stress incontinence in case of symptoms of stress incontinence and to demonstrate urge incontinence in case of symptoms of urge incontinence. In case of mixed incontinence, there was no correlation between symptoms and urodynamic diagnosis. Ambulatory monitoring has been investigated by other authors among patients of all ages ${ }^{11-15}$ and children. ${ }^{16}$ Their general conclusion was that ambulatory monitoring is more sensitive, compared to conventional cystometry, in detecting detrusor overactivity in patients with symptoms of urgency and/or frequency. In situations in which it is not possible to perform a conventional urodynamic investigation, for instance for patients who are unable to visit a urodynamic laboratory, it is feasible that a stress component can be demonstrated without a conventional urodynamic investigation. A thorough medical history combined with a thorough physical examination with stress testing, is a very good altemative.

DAI values are partly calculated from the frequency/volume chart variables and partly from the analysed pressure curves. The mean DAI does not show clinically significant differences for the different medical history categories (see figure 3) The clinical urodynamic diagnosis, however, does show clinically significant differences in mean DAI. Analysis of variance (oneway, statistical package SPSS/PC+) did not show statistically significant differences when comparing mean DAI values in the different medical history groups. This difference was present with regard to the clinical urodynamic diagnosis $(\mathbf{p}<0.0001)$, due to the motor urge incontinence, mixed incontinence and motor urge groups. The results indicate that assessing type of incontinence by means of medical history is not very reliable in this elderly group and that the DAI is a good tool for classifying elderly patients with lower urinary tract problems in the absence of infravesical obstruction.

In an earlier study ${ }^{10}$ describing the development of the DAI in a population of outpatients of all ages, a good correlation was found between DAI values and both the medical history classification and the clinical urodynamic diagnosis. Hence, 
medical history appears to be more reliable in younger patients than in those aged 60 or more.

Since the DAI is partly calculated from frequency/volume chart variables, it might be considered to use only these variables and establish detrusor activity non-invasively; this hypothesis needs to be investigated in future studies.

In table 28, correlating 'number of appliances used per day' and 'type of lower urinary tract disorder', it can be seen that pads were also used by those with a normal test result or motor urge without incontinence. A close look at the data revealed that these patients had a medical history of incontinence, although not daily; they used appliances to be on the safe side. No relation could be found between the reported use of appliances and clinical urodynamic diagnosis. Such a relation, however, was present between the objectified amount of urine loss during pad-testing and both the clinical urodynamic diagnosis and the medical history classification (table 29). Patients with objectified stress incontinence have lower losses compared to cases in which an urge component is involved. A well performed pad-test that allows for calculating mean $\mathrm{ml}$ of loss per incontinence episode and mean $\mathrm{ml}$ of loss per hour, might be able to discriminate between stress and urge incontinence; this hypothesis has to be investigated in future studies. In order to demonstrate objective results after therapy with respect to incontinence, it is probably better to perform pad-testing instead of relying on the patients' answer in this elderly group. If urine loss diminishes after treatment, patients can be advised to use fewer pads, in order to reduce costs.

\section{CONCLUSIONS}

Ambulatory monitoring is applicable in elderly patients, subjectively it is well tolerated and objectively it is able to assess detrusor activity during the filling phase.

Medical history is less reliable in elderly patients than in younger patients.

A relation was found between the amount of urine lost, objectified by pad-testing, and the type of lower urinary tract disorder, indicating that stress incontinence gives rise to lower losses than urge incontinence.

Results after therapy with respect to incontinence can be objectified by means of padtesting, which may be important for those in whom the medical history is expected not to be reliable.

The results suggest that a good strategy in elderly patients, who cannot come to the urodynamic laboratory, is to perform a thorough physical examination with stress testing to demonstrate a stress component, flowmetry combined with measuring residual urine to demonstrate infravesical obstruction and/or hypotonic bladder, and extramural ambulatory monitoring to demonstrate an urge component. It can even be 
CHAPTER 5

considered to perform non-invasive investigations only: physical examination, ultrasonic residue measurements, flowmetry, pad-testing and a frequency/volume chart. 


\section{REFERENCES}

1. Kok ALM, Voorhorst FJ, Halff-Butter CMC, Janssens J, Kenemans P

De prevalentie van urine-incontinentie bij oudere vrouwen

NtvG 1991; 135, 98-101

2. Yarnell JWG, Voyle GJ, Richards CJ, Stephenson TP

The prevalence and severity of urinary incontinence in women

J Epid Comm Health 1981; 35, 71-74

3. Herzog AR, Fultz NH, Normolle DP, Brock BM, Diokno AC

Methods used to manage urinary incontinence by older adults in the community

JAGS 1989; 37: 339-347

4. Holst $\mathrm{K}$, Wilson PD

The prevalence of female urinary incontinence and reasons for not seeking treatment

NZ Med J 1988; 756-758

5. Waalwijk van Doorn ESC van

Ambulatory Urodynamics; from phsysiological research to daily practice

Thesis, April 1993, University of Limburg

6. Abrams P, Blaivas JG, Stanton SL, et al

The standardisation of terminology of lower urinary tract function.

Scand J Urol Nephrol (suppl) 1988; 114: 5-19

7. International Continence Society Working Party on Urodynamic Equipment: Urodynamic equipment: technical aspect

J Med Eng Tech 1987; 11: 57

8. Waalwijk van Doorn ESC van, Remmers A, Janknegt RA

Extramural ambulatory monitoring during natural filling and normal daily activities: evaluation of 100 patients

J Urol 1991; 146: 124-131

9. Waalwijk van Doorn ESC van, Remmers A, Janknegt RA

Conventional and extramural ambulatory urodynamic testing of the lower urinary tract in female volunteers

J Urol 1992; 147: 1319-1326

10. Waalwijk van Doorn, ESC van, Remmers A, Ambergen AW, Janknegt RA

Detrusor Activity Index, quantification of detrusor overactivity by means of ambulatory monitoring

Detrusor Activity Index; a means to quantify detrusor overactivity

Neurourol Urodyn 1992; 11: 105

11. Bhatia NN, Bradley WE, Haldeman S

Urodynamics: continuous monitoring

J Urol 1982; 128: 963-968

12. Griffiths CJ, Assi MS, Styles RA, Ramsden PD, Neal DE

Ambulatory monitoring of bladder and detrusor pressure during natural filling

J Urol 1989; 142: 780-784

13. McInerney PD, Vanner TF, Harris SAB, Stephenson TP

Ambulatory urodynamics

Br J Urol 1991; 67: 272-274

14. Webb RJ, Ramsden PD, Neal DE

Ambulatory monitoring and electronic measurement of urinary leakage in the diagnosis of detrusor instability and incontinence

Br J Urol 1991; 68: 148-152 


\section{CHAPTER 5}

15. Webb RJ, Griffiths CJ, Zachariah KK, Neal DE

Filling and voiding pressures measured by ambulatory monitoring and conventional studies during natural and artificial bladder filling

J Urol 1991; 146: 815-818

16. Passereni-Glazel, Cisternino A, Artibani W, Pagano F

Ambulatory urodynamics: preliminary experience with vesico-urethral holter in children Scand J Urol Nephrol Suppl 1992; 141: 87-92 


\title{
NON INVASIVE URODYNAMICS BEHAVIORAL URGE SCORE
}

\begin{abstract}
In this study the objective was to investigate whether it is possible to avoid invasive urodynamics in female patients with complaints of urgency with or without incontinence by means of variables derived from drinking and voiding behaviour. A second aim was to score the severeness of bladder overactivity in each individual patient, expressed in a score called the behavioral urge score or BUS. This was based on the assumption that drinking and voiding behaviour can predict detrusor activity, by measuring urinary frequency, volume voided (functional bladder capacity), and amount of fluid drunk, the latter as a correction factor (drinking influences bladder behaviour). The tool used to establish this was backward stepwise logistic regression analysis, a statistical method that predicts whether an event or disorder will or will not occur, and identifies variables useful in making the prediction by producing a model in which the most valuable variables are incorporated. The model yields a probability (expressed between 0 and 1 ) of the disorder occurring, depending on the prevalence of the disorder. Variables entered into the model were; voided volume per hour, voided volume per voiding (functional bladder capacity), number of voidings per hour (frequency), drinking volume per hour, and number of voidings per litre of fluid drunk. A complete urodynamic investigation (combining both conventional urodynamics and extramural ambulatory monitoring) was used as a reference standard, to calibrate the model. From the results it could be concluded that differentiation between bladder overactivity and bladder non-overactivity by means of a frequency/volume chart is feasible and worthwhile.
\end{abstract}

A. Remmers, ${ }^{1}$ E.S.C. van Waalwijk van Doorn, ${ }^{1}$ A.W. Ambergen, ${ }^{2}$ R.A. Janknegt ${ }^{1}$ 'Department of Urology, University Hospital Maastricht; ${ }^{2}$ Department of Methodology and Statistics, Universtity of Limburg, Maastricht, The Netherlands

submitted for publication 



\section{INTRODUCTION}

Elderly patients with lower urinary tract complaints are often not referred for further investigation in order to establish a diagnosis and start treatment. This means that they receive either no treatment or 'trial-and-error-treatment'. In diagnosing bladder malfunctioning it is important to distinguish between disorders during bladder filling and those during bladder emptying. During bladder filling, on the one hand, detrusor overactivity may cause the urgency/frequency syndrome with or without incontinence, while detrusor hypoactivity or inactivity may cause overflow incontinence, and, on the other hand, sphincter weakness, as well as anatomical anomalies in the female, may cause stress incontinence. A malfunction during bladder emptying is caused by an infravesical obstruction or diminished detrusor contractility.

In this study, detrusor overactivity was concentrated upon. Until now an invasive urodynamic investigation was needed to objectively diagnose this condition. Furthermore, in this age of expensive sophisticated, high-tech equipment it is worthwile - from an economic point of view - to develop simple, low-cost diagnostics. The simple diagnostic methods can then be calibrated against the sophisticated equipment and methods.

Frequency/volume charts which record symptoms like urgency, frequency, voiding volume and incontinence are very helpful in the diagnosis of urinary frequency. ${ }^{1,2}$ In our outpatient clinic a correlation was observed between bladder behaviour, expressed in a frequency/volume chart, and bladder overactivity, although others ${ }^{3}$ have failed to find a correlation between a frequency/volume chart and cystometric findings. Van Waalwijk van Doorn ${ }^{4}$ reported that a conventional urodynamic investigation is unreliable for the exclusion of detrusor overactivity.

The aim of the present study was to investigate whether it is possible to avoid invasive urodynamics in patients with complaints of urgency with or without incontinence by means of variables derived from drinking and voiding behaviour. A further aim was to score the severeness of bladder overactivity in each individual patient.

\section{MATERIALS}

Frequency/volume charts were analysed for 216 consecutive female patients from the outpatient clinic and 48 female volunteers, who underwent an extensive computerized medical history questionnaire and a complete urodynamic evaluation (standard and ambulatory investigations). Charts from patients who did not drink or void during the investigative period, and/or were investigated for less than 3:30 hours, and/or voided less than twice, were excluded from the analysis. 


\section{METHODS}

Frequency/volume chart. In the frequency/volume chart, patients noted time and volume voided, time and volume drunk, and time of pad change. The period of time during which the patients kept the diary was also noted. From the chart the following variables could be calculated: (1) voided volume per hour, (2) voided volume per voiding (functional bladder capacity), (3) number of voidings per hour (frequency), (4) drinking volume per hour, and (5) number of voidings per litre of fluid drunk. These variables were chosen because bladder overactivity causes high frequency and small capacity. Drinking behaviour was also taken into account, because heavy drinkers void more frequently.

Statistical method. Backward stepwise logistic regression analysis was chosen for the statistical analysis. This method is used to predict whether an event or disorder will or will not occur, as well as to identify variables useful in making this specific prediction. It answers questions like 'Is there a correlation between coronary heart disease and smoking or hypertension?'. Variables that are potential predictors for the outcome have to be identified by expert knowledge. All possible important variables are then entered into a model. After this, logistic regression selects or identifies the valuable variables, i.e., those variables that have the best predictive value. After calculation, the model yields a probability of the occurrence of the disorder. Each patient then scores on a $0-1$ interval, depending on the outcome of the different variables in the frequency/volume chart.

Gold standard. The model has to be calibrated against a gold standard. In detrusor overactivity there is (as yet) no gold standard. The standard that comes closest to 'gold' is a full urodynamic workup, that is the combined diagnoses of a standard urodynamic investigation and extramural ambulatory monitoring. ${ }^{4}$ Since medical history is a very important tool in diagnosing patients with lower urinary tract problems, the medical history diagnosis or preclassification was also used as a reference standard.

Conventional urodynamic investigation. The conventional standard urodynamic investigation was performed in accordance with International Continence Society standards ${ }^{5.6}$ unless mentioned otherwise. It included free uroflowmetry, urethral pressure profilometry, filling cystometry $(35 \mathrm{ml}$ per minute with the patient in the sitting position), and a pressure-flow study. The filling phase was stopped when the patient indicated a strong desire to void. A $9 \mathrm{~F}$ Gaeltec catheter was used transurethrally to examine bladder ( 1 sensor) and urethral function ( 3 sensors), while a $5 \mathrm{~F}$ Gaeltec catheter was used rectally to measure abdominal pressure.

Extramural ambulatory monitoring. The method has been described by Van Waalwijk van Doorn. ${ }^{3}$ A $5 \mathrm{~F}$ Gaeltec dual sensor catheter was used to examine bladder and urethral function transurethrally, while a $5 \mathrm{~F}$ Gaeltec single sensor catheter was used rectally to measure abdominal pressure. The catheters were connected to a 
miniaturized microprocessor-controlled Holter monitor (Biolnterface). Patients were asked to keep a diary of important events, such as voiding (time and volume). drinking (time and volume), urge sensations, urine loss and remarks. Urine loss was demonstrated by means of pad-testing. The patient was asked to push the event button on the monitor when entering the toilet for voiding. This is of considerable importance in recognizing detrusor overactivity just before voiding (imminent voiding). After careful instruction, the patient left the hospital and resumed normal daily activities.

Medical history. An extensive, computerized, urological medical history questionnaire was used to establish medical history classification. The questionnaire has been tested for reproducibility and validity regarding lower urinary tract disorder. The agreement between the questionnaire classification and a full urodynamic workup was $69 \%$. kappa, agreement above chance concurrency, was 0.67 .

On the basis of the urodynamic diagnosis and the medical history classification patients were classified as 'overactive' or 'non-overactive'. Those with motor urge incontinence and motor urge were classified as 'overactive', while those with stress incontinence, other voiding problems, or a normal test result, and the volunteers, were classified as 'non-overactive'. Mixed incontinence was regarded separately, because these patients might be classified both ways.

Because two reference standards were used, two models were obtained. The first model predicts the outcome (overactive or non-overactive) with respect to the urodynamic diagnosis, the second model does the same with respect to the medical history diagnosis. Both models can then be used on an individual patient: after finishing the diary, variable values are entered into the model. It is then possible to calculate a score, the 'Behavioral Urge Score' or BUS.

\section{RESULTS}

Table 31 shows the urodynamic diagnosis and mean ages in the different groups. After classification, measurements of 134 female subjects with an 'overactive' bladder, 84 with a 'non-overactive' bladder and 46 with mixed incontinence were available for analysis. Table 32 shows the same for the medical history group. In this group, 81 scored 'overactive', 80 'non-overactive' and 103 had mixed incontinence. Tables 33 and 34 show the descriptive statistics for the variables initially entered into the logistic regression model in the urodynamic group and the medical history group respectively.

Tables 35 and 36 give the different variables with their significance (the importance of that variable's contribution to the model) and their coefficients B. after calculation of the model for both groups. 


\section{CHAPTER 6}

Table 31. Urodynamic diagnosis and mean age. +=overactive; -=non-overactive.

\begin{tabular}{lcccc} 
urodynamic diagnosis & & number & mean age & age range \\
\hline volunteers & - & 48 & 32 & $20-61$ \\
\hline normal & - & 11 & 43 & $24-67$ \\
\hline stress incontinence & - & 24 & 48 & $29-74$ \\
\hline motor urge incontinence & + & 89 & 48 & $17-75$ \\
\hline mixed incontinence & $?$ & 46 & 55 & $36-84$ \\
\hline motor urge & + & 45 & 45 & $17-73$ \\
\hline other voiding problems & - & 1 & 63 & \\
\hline total & & 264 & 46 & $17-84$
\end{tabular}

Table 32. Medical history diagnosis and mean age. $+=$ overactive; $=$ =non-overactive.

\begin{tabular}{lcccc} 
medical history diagnosis & & number & mean age & age range \\
\hline volunteers & - & 48 & 32 & $20-61$ \\
\hline stress incontinence & - & 23 & 51 & $17-75$ \\
\hline urge incontinence & + & 57 & 48 & $17-84$ \\
\hline mixed incontinence & $?$ & 103 & 50 & $19-83$ \\
\hline motor urge & + & 19 & 49 & $21-73$ \\
\hline other incontinence & - & 5 & 42 & $19-54$ \\
\hline other voiding problems & - & 4 & 38 & $19-63$ \\
\hline nocturnal enuresis & + & 6 & 33 & $17-67$ \\
\hline total & & 264 & 46 & $17-84$
\end{tabular}


Table 33. Variables and their descriptive statistics in the 'urodynamic' group. Volumes are in $\mathrm{ml}$. +=overactive; -=non-overactive.

\begin{tabular}{lcccccc} 
& \multicolumn{2}{c}{ mean } & \multicolumn{2}{c}{ s.d. } & \multicolumn{2}{c}{ range } \\
\cline { 2 - 7 } variable & + & - & + & - & + & - \\
\hline $\mathrm{N}$ voidings/hour & 0.86 & 0.70 & 0.42 & 0.31 & $0.12-2.59$ & $0.25-2.59$ \\
\hline mean vol. voided/voiding & 147 & 205 & 74 & 91 & $29-383$ & $66-500$ \\
\hline mean vol. voided/hour & 120 & 145 & 76 & 95 & $23-388$ & $28-672$ \\
\hline mean vol. drunk/hour & 142 & 187 & 65 & 123 & $38-396$ & $13-1082$ \\
\hline $\mathrm{N}$ voidings/liter drunk & 6.6 & 4.5 & 3.3 & 2.7 & $1.7-18.4$ & $1.7-20.0$
\end{tabular}

Table 34. Variables and their descriptive statistics in the 'medical history' group. Volumes are in $\mathrm{ml}$; +=overactive; -=non-overactive.

\begin{tabular}{lcccccc} 
& \multicolumn{2}{c}{ mean } & \multicolumn{2}{c}{ s.d. } & \multicolumn{2}{c}{ range } \\
\cline { 2 - 7 } variable & + & - & + & - & + & - \\
\hline $\mathrm{N}$ voidings/hour & 0.91 & 0.69 & 0.48 & 0.34 & $0.12-3.06$ & $0.25-2.58$ \\
\hline mean vol. voided/voiding & 138 & 205 & 72 & 94 & $29-360$ & $72-500$ \\
\hline mean vol. voided/hour & 120 & 139 & 80 & 95 & $23-388$ & $28-672$ \\
\hline mean vol. drunk/hour & 148 & 182 & 70 & 125 & $38-419$ & $12-1082$ \\
\hline $\mathrm{N}$ voidings/liter drunk & 6.8 & 4.4 & 3.5 & 2.5 & $1.7-18.4$ & $1.6-20.0$
\end{tabular}

Table 35. Parameters after logistic regression, 'urodynamic' group.

\begin{tabular}{lcc} 
variable & coefficient & $p$ \\
\hline mean vol. voided/voiding & -0.0066 & 0.0008 \\
\hline N voidings/litre drunk & 0.2348 & 0.0006 \\
\hline constant & 0.3447 & 0.5387
\end{tabular}


Table 36. Parameters after logistic regression, 'medical history' group.

\begin{tabular}{lcc} 
variable & coefficient & $p$ \\
\hline mean vol. voided/voiding & -0.0083 & 0.0007 \\
\hline N voidings/liter drunk & 0.2389 & 0.0012 \\
\hline constant & 0.1078 & 0.8613
\end{tabular}

Figure 5 shows the scores of both models in a plot. Because logistic regression selected the same variables for both models, the scores are almost equal. Therefore, it is logical to work with only one of the models. The model based on the urodynamic diagnosis was chosen, since the urodynamic diagnosis is an accepted standard for lower urinary tract disorders.

Figure 6 shows the so-called Receiver Operating Characteristic curve (ROC-curve), reflecting the quality of this predictive test. The more the curve approaches the upper right-hand corner, the higher the discriminative power of the test. Figure 7 shows sensitivity and specificity for each possible cutoff point of the score. Sensitivity equals specificity $(72 \%)$ at a cutoff point of 0.61 , which means that $72 \%$ of the urodynamically proven overactive bladders scored above 0.61 , while $72 \%$ of the urodynamically proven non-overactive bladders scored below 0.61 .

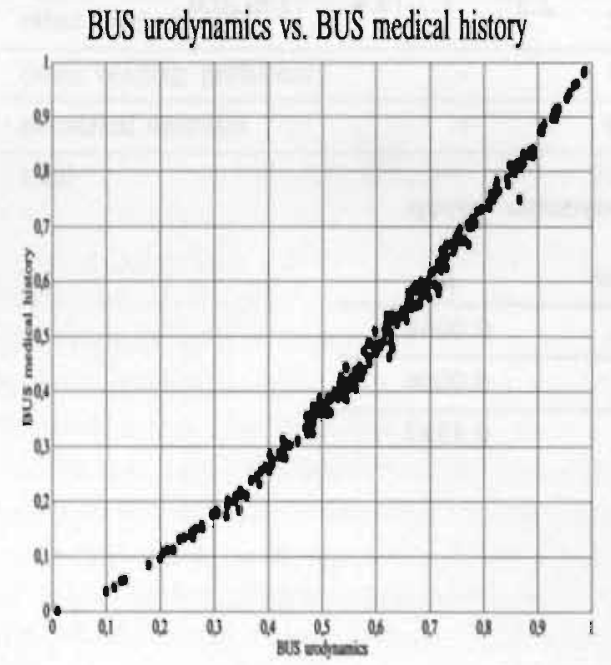

Figure 5.

BUS derived from the urodynamic diagnosis model plotted against that derived from the medical history model. 


\section{ROC-Curve}

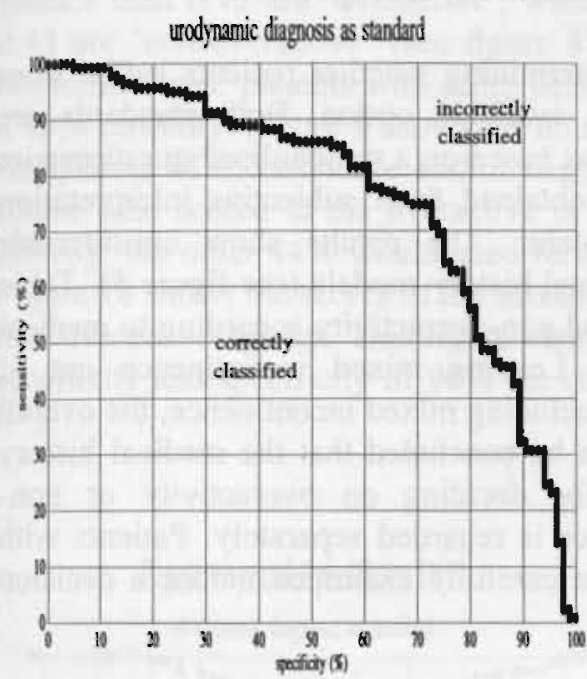

Figure 6.

Receiver Operating Characteristic curve: the more the curve approaches the upper right comer, the higher the discriminative power of the test. The urodynamic diagnosis is used as reference standard.

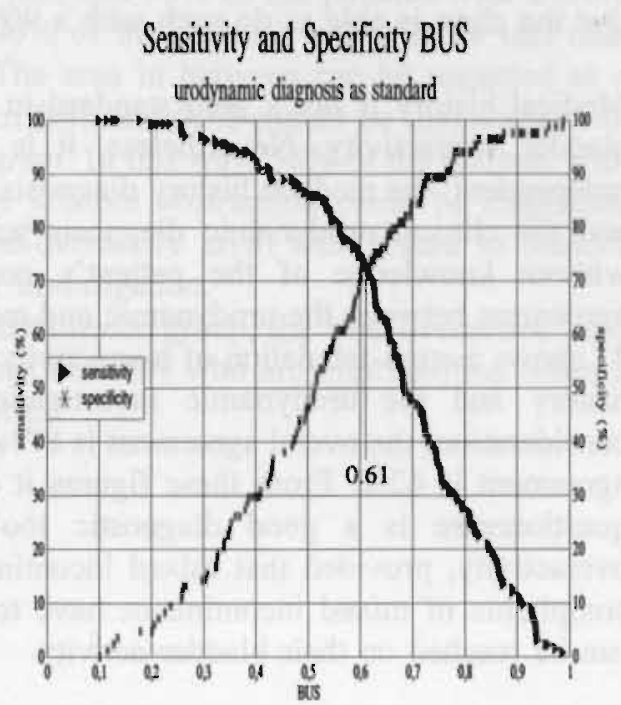

Figure 7.

Relationship between sensitivity, specificity and the score of the model that used the urodynamic diagnosis as reference standard. Sensitivity equals specificity $(72 \%)$ at a cutoff point of 0.61 .

\section{DISCUSSION}

Logistic regresssion analysis is a powerful tool for determining which factors contribute to a certain disorder or event. The outcome variables of a diagnostic test can be used to construct a model that optimally approximates the gold standard. Frequently, the gold standard test is relatively expensive and/or invasive, as in the example of bacteriological investigation for symptoms of a urinary infection or an angiogram for arterial obstruction. In lower urinary tract disorders the standard is a urodynamic investigation, which is invasive and time consuming. It was therefore attempted to develop a test which is non-invasive, cheap, and simple to use by patients, nurses, and doctors. Frequency/volume charts are often used subjectively by urologists, gynaecologists, general practitioners and other workers in the field of lower urinary tract disorders by determining whether a patient suffers from urgency or urge incontinence. Larsson ${ }^{3}$ found no correlation between cystometric findings and frequency/volume chart variables, probably because cystometry is an unreliable investigation in case of detrusor instability. ${ }^{4}$ In the present study frequency/volume chart variables were calibrated against a complete urodynamic investigation, including 
ambulatory monitoring, to predict bladder activity quantitatively. The results showed that the chart is able to do such with a $90 \%$ sensitivity and specificity.

Medical history is not a gold standard in determining whether patients suffer from bladder overactivity. Nevertheless, it is an available option. Both standards are independent: the medical history diagnosis was based on a standardised questionnaire and the clinical urodynamic diagnosis was obtained from subjective interpretation without knowledge of the patient's complaint. The results show considerable agreement between the urodynamic and medical history models (see figure 5). Table 37 shows a cross-tabulation of overactivity and non-overactivity according to medical history and the urodynamic investigation. Leaving mixed incontinence out of consideration, the overal agreement is $87 \%$; including mixed incontinence, the overall agreement is $62 \%$. From these figures it can be concluded that the medical history questionnaire is a good diagnostic tool for deciding on overactivity or nonoveractivity, provided that mixed incontinence is regarded separately. Patients with complaints of mixed incontinence have to be carefully examined before a decision can be reached on their bladder activity.

Table 37. Cross tabulation regarding overactivity and non-overactivity according to medical history and urodynamic investigation.

\begin{tabular}{ll|ccc|c} 
& \multicolumn{5}{c}{ urodynamic diagnosis } \\
\cline { 3 - 6 } medical & over & over & non-over & mixed inc. & total \\
history & non-over & 13 & 7 & 5 & 81 \\
& mixed inc. & 52 & 61 & 6 & 80 \\
& total & 134 & 84 & 46 & 103 \\
\hline
\end{tabular}

Clinical tests hardly ever have a sensitivity and specificity of $100 \%$; most tests show an overlap in outcomes for healthy and diseased persons. It is therefore necessary to define a cutoff point in the outcomes or scores to be able to distinguish between predicted healthy and diseased persons. In choosing a cutoff point, it is important whether the clinician wants to have a highly sensitive or a highly specific test. A highly sensitive test implies that more healthy subjects are classified as diseased, whereas a highly specific test favours non-diseased classifications. A sensitivity of $90 \%$ means that $90 \%$ of the patients with the anomaly are scored correctly, a specificity of $90 \%$ means that $90 \%$ of the patients without the anomaly are scored 
correctly. If we apply this to figure 6 , we find that $90 \%$ of the patients with a score greater than 0.72 are 'overactive', while $90 \%$ of the patients with a score less than 0.43 are 'non-overactive' (see figure 8). The area in between can be regarded as a borderline area: patients who score between 0.43 and 0.72 cannot be diagnosed with a $90 \%$ certainty. Figure 9 shows the nomogram. In this way, $56 \%$ of the patients with complaints of incontinence and/or urgency without obstruction could be diagnosed (those who scored in the overactive or non-overactive area) with regard to bladder activity; the other $44 \%$ would need further investigation.

Figure 10 shows the scores of the mixed incontinence group, the 'non-overactive' and the 'overactive' group. This figure visualises the $10 \%$ who are misclassified when a sensitivity and specificity of $90 \%$ are chosen.

Sensitivity and Specificity BUS

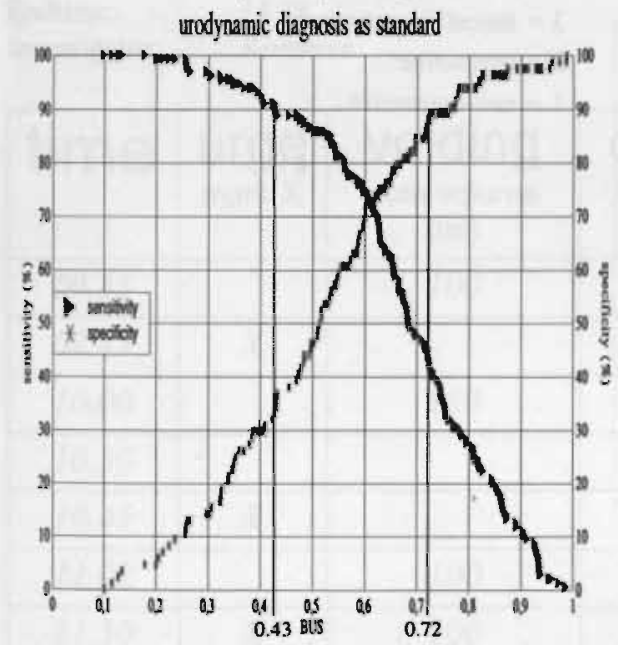

Figure 8.

Sensitivity, specificity and score in the urodynamic diagnosis group. Vertical lines indicate the cutoff points where sensitivity $=$ specificity $=90 \%$. 


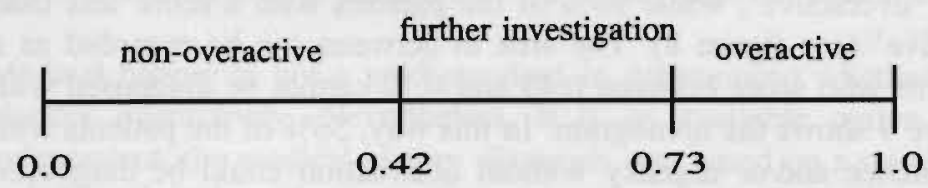

Figure 9.

Nomogram for detrusor activity, scored with a frequency/volume chart.

BUS and Urodynamic Diagnosis

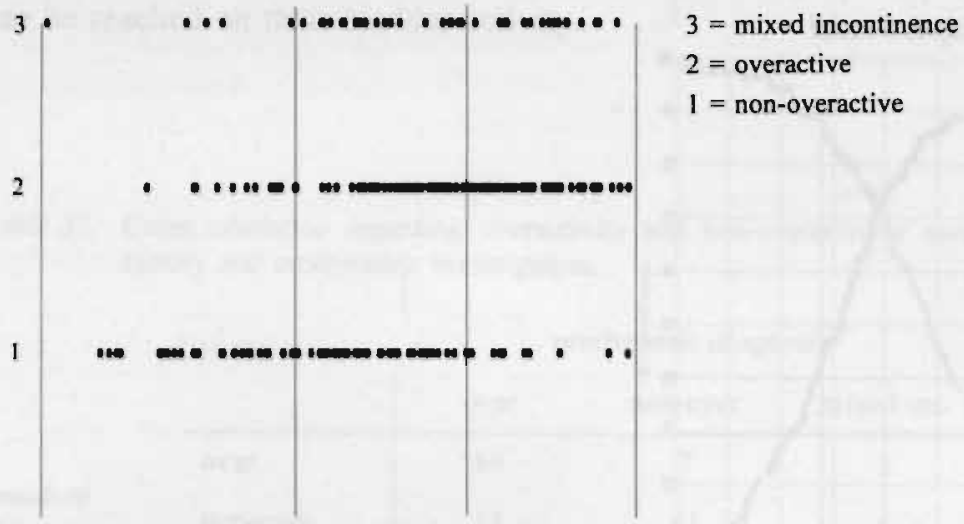

Figure 10.

Score of patients with non-overactive bladders, overactive bladders and mixed incontinence.

\section{CliniCAL APPLICATION}

In order to perform this diagnostic test, patients have to fill in a frequency/volume chart in which they at least note voiding time and volume, and drinking time and volume. Figure 11 shows an example of a frequency/volume chart kept by a female patient. To calculate BUS, it is first necessary to calculate the input into the logistic regression model. This input comprises the variables 'mean volume voided per voiding' and 'number of voidings per litre of fluid drunk'. In the example patient these values are respectively $121 \mathrm{ml}$ and 7 . If applying this on the logistic regression 
model and using the values mentioned in table 35 for the constant $\mathrm{C}$ and the coefficients $\mathrm{B}_{1}$ and $\mathrm{B}_{2}, \mathrm{Z}$ is 1.8197 and the BUS is 0.77 (see figure 12). According to the nomogram, this patient has to be classified 'overactive'. When outflow disorders are excluded (for instance by ultrasonic residue measurements after voiding), the example patient can be treated with a bladder relaxing agent, thus avoiding a complete urodynamic investigation or 'trial-and-error-therapy'. Furthermore, by means of BUS calculation it is possible to quantify bladder activity and judge the severeness of the patients' complaints.

$\begin{array}{lll}\text { Patient data: } & \begin{array}{l}\text { name: } \\ \text { gender: } \\ \text { date of birth: }\end{array} & \begin{array}{l}X X \\ \text { female } \\ 05-05-50\end{array} \\ & \begin{array}{l}16-03-94 \\ \text { Date: }\end{array} & \\ \text { Starttime: } & 09.04 & \\ \text { Endtime: } & 14.49 & \\ \text { Investigator: } & \text { Remmers } & \end{array}$

\begin{tabular}{|c|c|c|c|c|}
\hline time & $\begin{array}{c}\text { urge } \\
\text { mark } x\end{array}$ & $\begin{array}{c}\text { voiding } \\
\text { note volume } \\
(\mathrm{ml})\end{array}$ & $\begin{array}{c}\text { drinking } \\
\text { note volume } \\
(\mathrm{ml})\end{array}$ & remarkS \\
\hline 09.35 & & 100 & 200 & urine loss, dash \\
\hline 09.45 & $X$ & & & \\
\hline 10.00 & & 150 & & urine loss, dash \\
\hline 10.30 & & & 200 & \\
\hline 10.45 & $X$ & & & \\
\hline 11.00 & & 100 & & \\
\hline 11.30 & $X$ & 100 & 200 & \\
\hline 12.35 & $X$ & 100 & & \\
\hline 12.45 & & & 200 & \\
\hline 13.30 & & & 200 & \\
\hline 13.45 & $X$ & 100 & & \\
\hline 14.30 & & 200 & & \\
\hline
\end{tabular}

Figure 11.

Example of a diary. 


$$
\begin{aligned}
Z= & \text { constant }+\left(B_{1} \times \text { variable } e_{1}\right)+\left(B_{2} \times \text { variable } e_{2}\right)+\ldots+\left(B_{n} \times \text { variable } e_{n}\right) \\
= & 0.3447+(-0.0066 \times \text { mean volume voided per voiding })+(0.2348 \times N \text { voidings } \\
& \text { per litre of fluid drunk }) \\
= & 0.3447+(-0.0066 \times 121)+(0.2348 \times 7) \\
= & 1.1897
\end{aligned}
$$

$$
\mathrm{BUS}=\frac{1}{1+\mathrm{e}^{-\mathrm{z}}}=\frac{1}{1+\mathrm{e}^{-1.1897}}=0.77
$$

Figure 12.

Logistic regression model with variable values of the example patient.

\section{CONCLUSIONS}

Differentiation between bladder overactivity and bladder non-overactivity by means of a voiding and drinking diary is feasible and worthwhile.

Patients with complaints of mixed incontinence have to be carefully examined to decide on bladder activity.

After exclusion of outflow disorders:

- patients who have a BUS value $\geq 0.72$ can be considered as having motor urge incontinence);

- patients who have a BUS value $\leq 0.43$ and who have a postive stress test can be considered as suffering from stress incontinence;

- patients with BUS values between 0.43 and 0.72 need further evaluation. 


\section{REFERENCES}

1. Baily $\mathbf{R}$, Shephard A, Tribe B

How much information can be obtained from frequency/volume charts?

Proceedings ICS 1990, Neurourol Urodyn 9(4): $382-383$

2. Saito M, Kondo A, Kato T, Yamada Y

Frequency-volume charts: comparisons of frequency between elderly and adult patients

Br J Urol 1993; 72: 38-41

3. Larsson G, Abrams P, Victor A

The frequency/volume chart and cystometry in motor urgency: no correlation.

Proceedings ICS 1990, Neurourol Urodyn 9(4): 384-385

4. Waalwijk van Doorn ESC van, Remmers A, Janknegt RA

Extramural ambulatory monitoring during natural filling and normal daily activities: evaluation of 100 patients

J Urol 1991; 146, 124-131

5. Abrams P, Blaivas JG, Stanton SL, et al

The standardisation of terminology of lower urinary tract function

Scand J Urol Nephrol (suppl) 1988; 114: 5-19

6. International Continence Society Working Party on Urodynamic Equipment: Urodynamic equipment: technical aspect

J Med Eng Tech 1987; 11:57

7. Waalwijk van Doorn ESC van, Remmers A, Janknegt RA

Conventional and extramural ambulatory urodynamic testing of the lower urinary tract in female volunteers

J Urol 1992; 147: 1319-1326 


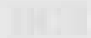

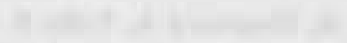

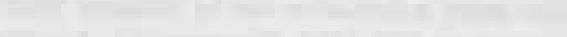

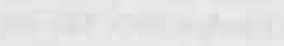

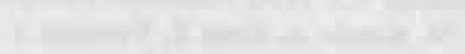

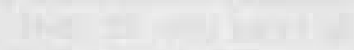

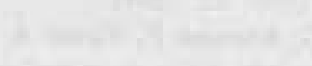

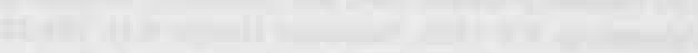

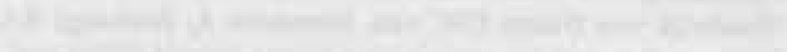

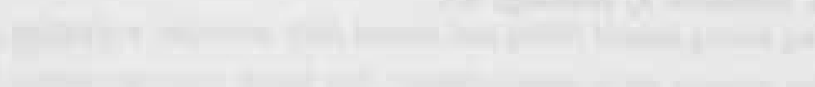

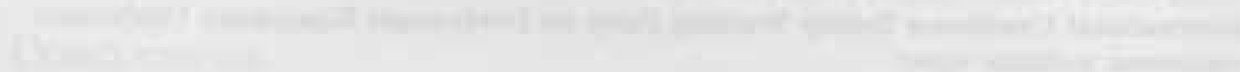

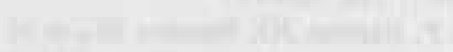

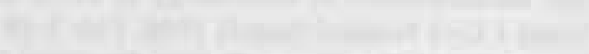
(1) - 


\section{APPLICABILITY OF THE BEHAVIORAL URGE SCORE}

\section{ABSTRACT}

This study was performed to evaluate whether the Behavioral Urge Score is capable of showing differences during therapy for detrusor overactivity during the filling phase. Fifteen patients were treated with emepronium carrageenate (a quaternary ammonium compound with anticholinergic properties with a mild bladder relaxing effect) and 8 with oxybutynin chloride (an anti-cholinergic agent with a strong bladder-relaxing effect). During treatment the BUS was expected to decrease compared to the initial pre-treatment score. Furthermore, the BUS was tested for reliability by comparing the initial BUS with that during placebo treatment. The mild effect of emepronium carrageenate on detrusor function is expressed in a slight, though statistically significant, decrease in the BUS value. The strong effect of oxybutynin chloride was expressed in an evident, significant decrease in BUS value. This result is supported by objective results obtained from invasive urodynamics, indicating that the BUS is capable of detecting therapy changes with regard to detrusor overactivity. The placebo study showed no decrease in BUS values under placebo treatment. It could be concluded that the BUS is a reliable tool for assessing detrusor activity in a general outpatient group. A high correlation was found between changes in BUS values and subjective results before and during the treatment period, indicating clinical significance. Although it is expected that the BUS will also prove to be applicable in an elderly population, it will have to be used and tested in such a population to make sure.

A. Remmers E.S.C. van Waalwijk van Doorn, R.A. Janknegt Department of Urology, University Hospital Maastricht, The Netherlands

submitted for publication 


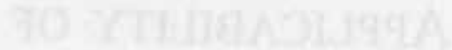

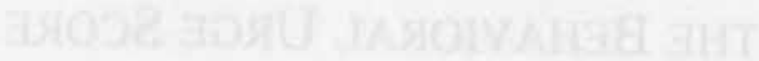

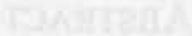

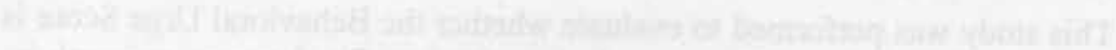
15. -

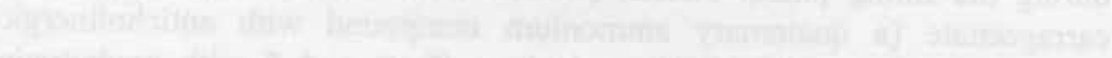

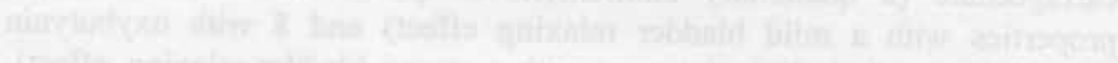
WT:

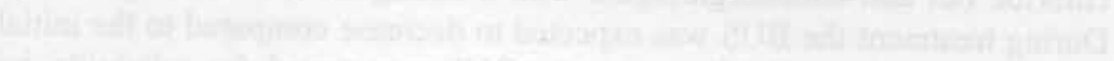

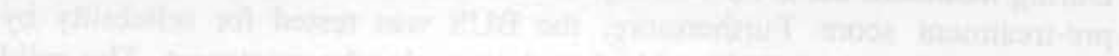

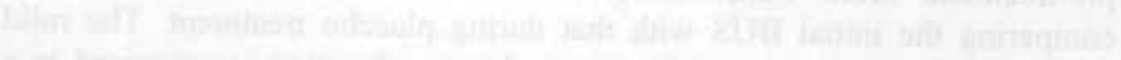

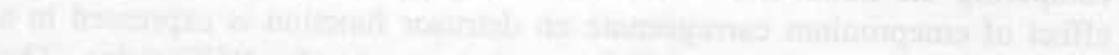

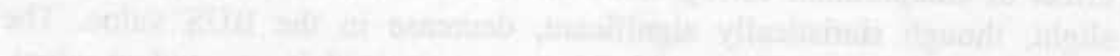

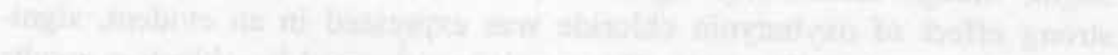

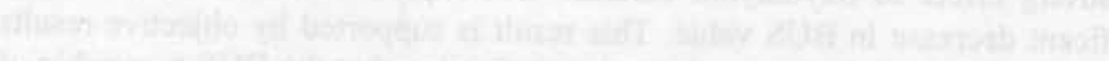

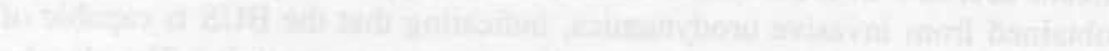

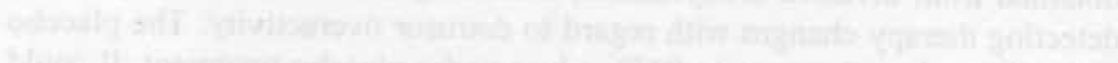

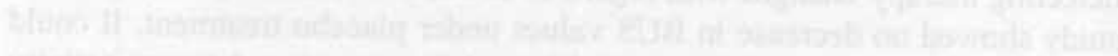

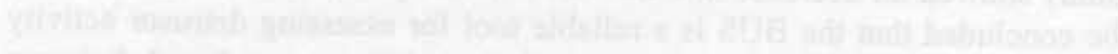

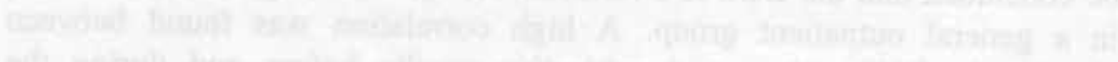

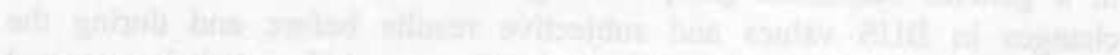

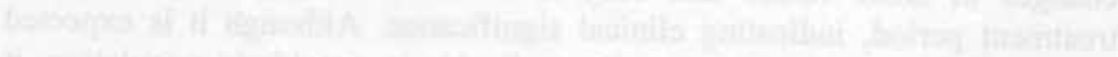

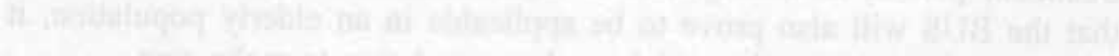

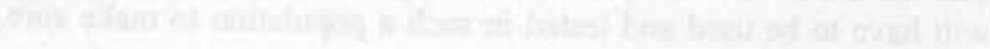




\section{INTRODUCTION}

Among elderly, especially mentally and/or physically handicapped people suffering from urinary incontinence, simple urodynamic investigations which are applicable onsite are very helpful in the reduction of economic costs due to incontinence and the improvement of quality-of-life. In other words, they enable patients to receive adequate diagnostic intervention on which therapy can be based. For these reasons the Behavioral Urge Score or BUS was developed. It is a simple, low-cost diagnostic tool, based on parameters from the frequency/volume chart, which predicts detrusor activity. Logistic regression analysis was used to calculate a model, that requires input from the frequency/volume chart from an individual patient. Entering the data from the frequency/volume chart into the model results in a score between 0 and 1 , the BUS, as a quantitative expression of detrusor activity. Since it is non-invasive and no great expert knowledge is required to interpret the test results, it can easily be used in the primary echelon of health care (e.g. general practitioner, nursing home physician) thus avoiding 'trial-and-error-treatment'.

The aim of this study was to assess the applicability of this new diagnostic tool. To establish this, it is necessary to investigate relevance, validity, reliability, and practical appropriateness. To assess validity, the test result should be compared with a 'gold' standard. For lower urinary tract problems no gold standard is as yet available; the best available and most generally accepted standard is a full urodynamic workup. Ambulatory monitoring is a good standard with respect to detrusor activity ${ }^{1-8}$; the 'detrusor activity index' (DAI) expresses detrusor activity quantitatively. ${ }^{9}$ In this study the ability of BUS to assess improvement after therapy was tested and compared with the corresponding DAI-values. Since the BUS quantifies detrusor activity, therapy should be a bladder relaxing agent. To assess reliability it is necessary to perform the test twice on the same patient, under identical measuring circumstances, by means of test-retest analysis. In this study, placebo treatment was used: measurements have been made before and during placebo treatment. Placebo therapy nearly always causes a positive effect, hence test circumstances become more difficult and results more reliable.

\section{MATERIALS \& METHODS}

Data from two different clinical trials have been used to assess BUS' ability to measure results after therapy and reproducibility. The first trial was a prospective study in which 15 ( 13 female and 2 male) patients, mean age 49, range 26-64, were treated with emepronium carrageenate 4 tid $250 \mathrm{mg}$ during 14 days. The second trial was a prospective, double blind, placebo controlled, cross-over study in which 8 (7 female and 1 male) patients, mean age 58 , range $40-71$, were treated with oxybutynin chloride 3 tid $5 \mathrm{mg}$ during 7 days. In between placebo and oxybutynin chloride treatment a wash-out period of 1 week was undertaken. Both trials were performed in 
accordance with the ethical standards defined in the Declaration of Helsinki, and written informed consent was obtained. Emepronium carrageenate is a quaternary ammonium compound with anti-cholinergic properties. It inhibits bladder contractions by blocking the acetylcholine receptors. Clinical trials have proved that emepronium carrageenate increases bladder capacity, delays the desire to void and reduces voiding frequency. ${ }^{10-13}$ Oxybutynin chloride is an anti-cholinergic agent with a strong bladder relaxing effect: it delays first desire to void, increases maximum cystometric capacity, reduces detrusor overactivity, and decreases daytime voiding frequency. ${ }^{14,15,16}$

Both trials included patients with detrusor overactivity proved during extramural ambulatory monitoring (DAI values $\geq 0.50$ ). The method has been described by Van Waalwijk van Doorn. ${ }^{1,29}$ All patients completed a frequency/volume chart and an ambulatory investigation before and during treatment.

To assess BUS' ability to measure result after therapy, initial BUS values were compared with BUS values during treatment with either emepronium carrageenate or oxybutynin chloride. For reliability testing initial BUS values and BUS values during placebo treatment were compared. Since extramural ambulatory monitoring already showed its value for assessing results after bladder relaxing therapy, ${ }^{16}$ BUS values were also compared with DAI values in all treatment modalities. Testing for statistical significance was performed using the Wilcoxon matched-pairs signed-rank test.

\section{RESULTS}

Ability to assess result after therapy. Figure 13 shows individual BUS values before and during treatment with emepronium carrageenate. The mean BUS decreased from 0.45 to 0.38 , significance testing showed statistically significant difference $(p=0.02)$. The corresponding DAI values are shown in figure 14; the mean DAI decreased from 0.68 to $0.58(\mathrm{p}=0.01)$. Figure 15 shows individual BUS values before and during treatment with oxybutynin chloride; mean BUS decreased from 0.41 to 0.27 , which was statistically significant $(\mathrm{p}=0.01)$. The corresponding DAI values are shown in figure 16, mean DAI decreased from 0.66 to $0.44(\mathrm{p}=0.02)$. 


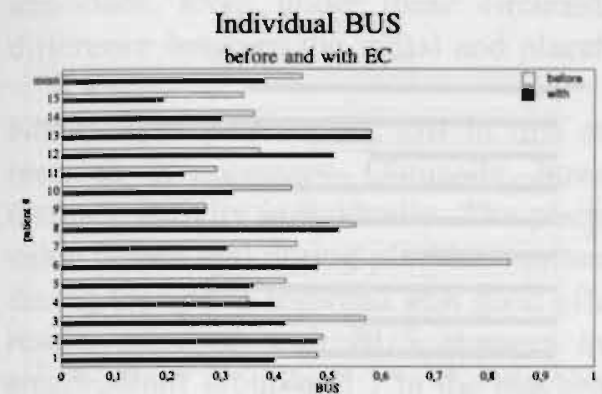

Figure 13.

Initial and emepronium carrageenate (EC) BUS values for each patient; mean BUS values are also shown.

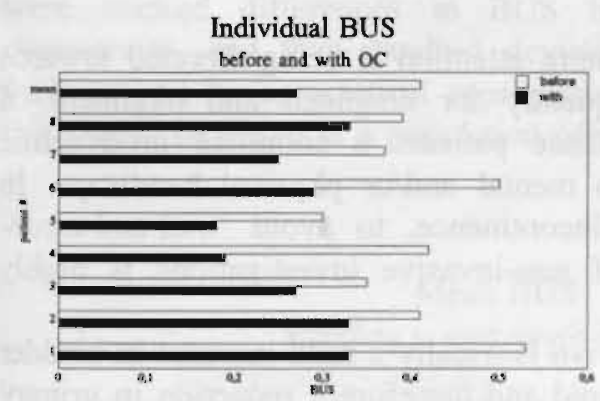

Figure 15.

Initial and oxybutynin chloride (OC) BUS values for each patient; mean BUS values are also shown.

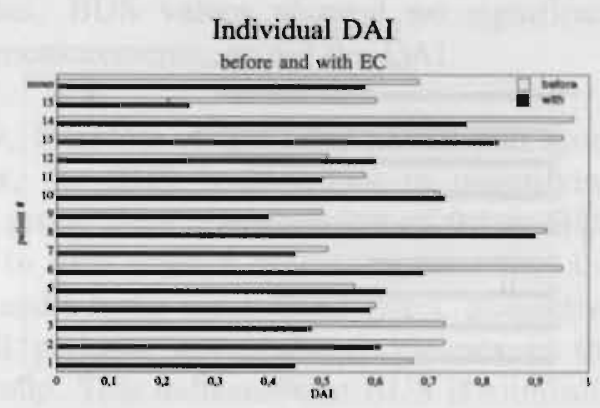

Figure 14.

Initial and emepronium carrageenate (EC) DAl values for each patient; mean DAI values are also shown.

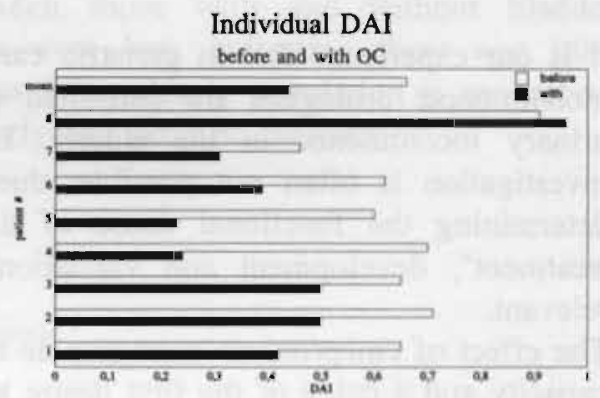

Figure 16.

Initial and oxybutynin chloride $(\mathrm{OC}) \mathrm{DAI}$ values for each patient; mean DAI values are also shown.

Reliability. Figure 17 shows individual initial and placebo BUS values, the mean BUS decreased (statistically not significant; $p=0.58$ ) from 0.41 to 0.38 . Figure 18 shows the corresponding DAI values, the mean DAI decreased from 0.66 to 0.58 . DAI did not show a statistically significant change either $(p=0.16)$. To establish variability of BUS, descriptive statistics of the placebo were subtracted from the initial BUS. The mean difference was 0.029 , with a standard deviation (or variance) of 0.110 . 


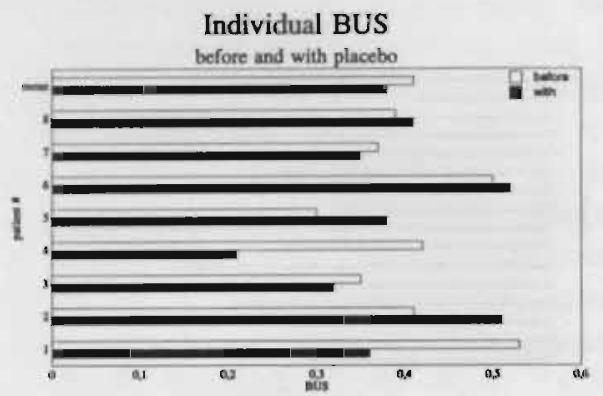

Figure 17.

Initial and placebo BUS values for each patient; mean BUS values are also shown.

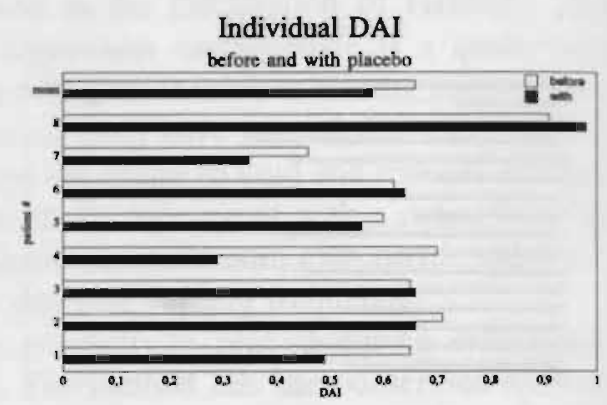

Figure 18.

Initial and placebo DAI values for each patient; mean DAI values are also shown.

\section{DISCUSSION}

It is our experience that in geriatric care more attention is being directed towards incontinence: urologists are consulted frequently for diagnosis and treatment of urinary incontinence in the elderly. In these patients a complete urodynamic investigation is often not possible, due to mental and/or physical handicaps. In determining the functional cause of the incontinence, to avoid 'trial-and-errortreatment', development and validation of non-invasive investigations is highly relevant.

The effect of emepronium carrageenate in vivo is usually a mild increase in bladder capacity and a delay of the first desire to void and therefore a reduction in urinary frequency. ${ }^{10,11}$ In the present study, there was a statistically significant decrease in both the mean BUS and mean DAI. Clinically, this difference was not very significant; emepronium carrageenate had only a mild effect. Oxybutynin chloride, a strong bladder relaxing agent, showed a more evident decrease in both BUS and DAI values. Since the BUS demonstrated the mild effect of emepronium carrageenate and the strong effect of oxybutynin chloride which was in agreement with the decrease in DAI values, it can be stated that BUS is capable of detecting improvement during therapy with regard to detrusor overactivity.

In one and the same individual, results of different measurements are never exactly the same and outcome can vary within certain ranges. Therefore, a certain variation is acceptable in reliability testing. The placebo study showed that the standard deviation or variation of the mean difference was 0.11 , which is acceptable within a scoring range from 0 to 1 . Although reproducibility should be tested in such a way that test and retest are performed under the same circumstances, retest was actually performed while patients used placebo therapy, and circumstances did change. However, when using placebo, circumstances become more difficult, as patients are under the impression that something is happening, in which case objective results become very 
important. Even under these circumstances, BUS values showed no significant difference between the initial and placebo measurements, as did the DAI.

Numbers of patients are low in this study, therefore it has little power and more research is necessary. Clinically, however, the BUS is important in quantifying detrusor activity individually. The placebo group showed a variation of 0.1 in BUS value before and during placebo treatment. In such cases, a decrease greater than 0.1 during therapy is regarded as a good effect and a lesser result as no effect. Subjective results matched with BUS changes in all patients, except for 2 patients in the emepronium group and 1 in the placebo group. This indicates that BUS is clinically significant.

It is not expected that the BUS shows different results in an elderly population, since it expresses functional bladder behaviour and does not reveal anything about underlying causes, which could be different among the elderly compared to younger people. Figure 19 shows mean BUS and standard deviations in an elderly outpatient group ( $\mathrm{N}=63)$, compared with the urodynamic diagnosis. The figure shows that there were marked differences in BUS between those with and without bladder overactivity, and that standard deviations were low, indicating there was little variance. As far as practical appropriateness in an elderly population is concerned, this should be tested in a population of elderly and geriatric patients.

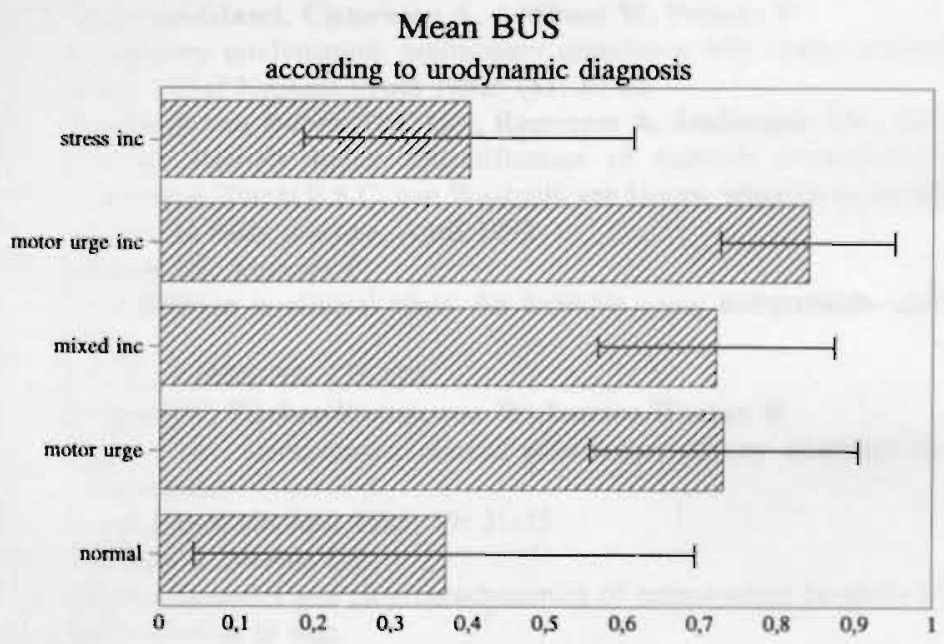

Figure 19.

BUS values in a group of patients $(\mathrm{N}=63)$ aged 60 and over compared with the urodynamic diagnosis. Standard deviations are also shown. 


\section{CONCLUSIONS}

The mild effect of emepronium carrageenate and the strong effect of oxybutynin chloride on detrusor function is expressed in, respectively, a slight and an evident decrease in BUS. This result is supported by the DAI, indicating that the BUS is capable of showing differences due to therapy.

The placebo study did not show a decreased BUS under placebo treatment, which was also supported by the DAI. Therefore, it can be stated that the BUS is a reliable tool for assessing detrusor activity.

Objective changes in BUS values during therapy, including placebo, correlate highly with clinical, subjective changes.

Although it is expected that the BUS is also applicable in an elderly population, it will have to be used and tested in such a population to make sure. 


\section{REFERENCES}

1. Waalwijk van Doorn ESC van, Remmers A, Janknegt RA

Extramural ambulatory monitoring during natural filling and normal daily activities: evaluation of 100 patients

J Urol 1991; 146: 124-131

2. Waalwijk van Doorn ESC van, Remmers A, Janknegt RA

Conventional and extramural ambulatory urodynamic testing of the lower urinary tract in female volunteers

J Urol 1992; 147: 1319-1326

3. Bhatia NN, Bradley WE, Haldeman S

Urodynamics: continuous monitoring

J Urol 1982; 128: 963-968

4. Griffiths CJ, Assi MS, Styles RA, Ramsden PD, Neal DE

Ambulatory monitoring of bladder and detrusor pressure during natural filling J Urol 1989; 142: 780-784

5. McInerney PD, Vanner TF, Harris SAB, Stephenson TP

Ambulatory urodynamics

Br J Urol 1991; 67: 272-274

6. Webb RJ, Ramsden PD, Neal DE

Ambulatory monitoring and electronic measurement of urinary leakage in the diagnosis of detrusor instability and incontinence

Br J Urol 1991; 68: 148-152

7. Webb RJ, Griffiths CJ, Zachariah KK, Neal DE

Filling and voiding pressures measured by ambulatory monitoring and conventional studies during natural and artificial bladder filling

J Urol 1991; 146: 815-818

8. Passereni-Glazel, Cisternino A, Artibani W, Pagano F

Ambulatory urodynamics: preliminary experience with vesico-urethral holter in children

Scand J Urol Nephrol Suppl 1992; 141: 87-92

9. Waalwijk van Doorn ESC van, Remmers A, Ambergen AW, Janknegt RA

Detrusor Activity Index. Quantification of detrusor overactivity by means of ambulatory monitoring. Thesis E.S.C. van Waalwijk van Doorn, ambulatory urodynamics from physiological research to daily practice, April 1993

10. Massey JA, Abrams P

Dose titration in clinical trials. An example using emepronium carrageenate in detrusor instability

Br J Urol 1986; 58: 125-128

11. Bagger PV, Fischer-Rasmussen W, Iversen Hansen $\mathbf{R}$

Emepronium carrageenate: clinical effects and urinary excretion in treatment of female urge incontinence

Scand J Urol Nephrol 1985; 19: 31-35

12. Pilbrant $\AA$, Norlén LJ

Pharmacokinetics and pharmacodynamics of emepronium bromide $\left(\right.$ Cetiprin ${ }^{R}$ ) after intravenous administration in man

Acta pharmacol et toxicol 1985; 56: 289-297

13. Cardozo LD, Stanton SL

An objective comparison of the effects of parenterally administered drugs in patients suffering from detrusor instability

J Urol 1979; 122: 58-59 


\section{CHAPTER 7}

14. Holmes DM, Montz FJ, Stanton SL

Ox hutynin versus propantheline in the management of detrusor instability. A patient-regulated variable dose trial

Br J Ohstet \& Gynaecol 1989: 96: 607-612

15. Tapp AJS, Cardozo LD, Versi E, Cooper D

The treatment of detrusor instability in post-menopausal women with oxybutynin chloride: a double blind placebo controlled study

Br J Obestet Gynaecol 1990: 97: 521-526

16. Waalwijk van Doorn ESC van, Zwiers W

Ambulatory monitoring to assess the efficacy of oxybutynin chloride in patients with mixed incontinence

Eur Urol 1990; 18: 49 


\title{
SUMMARY AND CONCLUSIONS
}

\author{
A. Remmers \\ Department of Urology, University Hospital Maastricht, The Netherlands
}



Lower urinary tract problems, and especially incontinence, constitute a major health problem for many patients. Although not directly related to mortality, incontinence has both social and economic effects. Social effects are, for instance, the fear of accidentally wetting oneself, or even worse, wetting the couch on which one is sitting while visiting some friends; or the fear of smelling. This might cause patients to become socially isolated. When they go into town, the shopping route often goes from one place with a public toilet to the other. Economically, it leads to costs for patients and for the national insurance institutions. Both spend large amounts of money for pads. For these reasons, caregivers are now spending more time and attention on urinary incontinence. Sophisticated, high-tech, but expensive investigations and models are being developed to tackle and solve the problem.

In elderly patients the problem is of a somewhat different nature. These patients often do not seek medical help and believe that incontinence is an inevitable part of old age. Fortunately, this attitude is changing, thanks to the fact that the subject can nowadays be discussed more frankly. A disadvantage is that costs have increased: most elderly patients now visit their general practitioner for a prescription for pads or pads are supplied to them in the nursing home or home for the elderly in which they reside. The high-tech urodynamic equipment is often not suitable for this elderly group, especially not for the frail elderly with mental and physical impairments. The costs will only increase, since more people are getting old and old people live longer. Hence, the question arises if and how the problem of lower urinary tract dysfunction, especially incontinence in the elderly, can be tackled in the near future. The present project has been performed to contribute to the solution of this problem.

Chapter 1 provides an introduction in which the aims were formulated:

- studying the epidemiology of lower urinary tract dysfunction in the elderly:

a. in the literature;

b. in a population of inhabitants of homes for the elderly;

- evaluation of extramural ambulatory urodynamics as a relatively simple diagnostic tool, in a group of outpatients aged 60 and over;

- developing and assessing the applicability of a simple diagnostic tool, based on a frequency/volume chart, for scoring bladder activity qualitatively and quantitatively.

Chapter 2 gives an overview of the international literature on the prevalence of urinary incontinence and other lower urinary tract disorders. It is difficult to indicate precisely the prevalence of urinary incontinence: the studies discussed here have been carried out in various settings, with different methods of data collection, and using different definitions of urinary incontinence. Categorizing the different studies for study setting, data source and definition of urinary incontinence used, it can be concluded that urinary incontinence occurs in about $20 \%$ of elderly males and in about $35 \%$ of elderly females (measured from the age of 60 and upwards). The difference in prevalence between males and females might be due to the occurrence of stress incontinence in females. In approximately $80 \%$ of the incontinent subjects an urge component is involved. 
Next to the literature survey, the extent of the urinary incontinence and other voiding disorders was also assessed in a Dutch population of elderly people. It was chosen to perform an epidemiological survey among inhabitants of homes for the elderly, in order to:

- estimate the prevalence and severity of urinary incontinence;

- estimate the prevalence of different types of urinary incontinence and lower urinary tract disorders;

- evaluate anomalies often associated with incontinence and

- evaluate the burden on the patient resulting from incontinence.

The survey was performed by means of a written, self-administered questionnaire, since lower urinary tract disorders are still a taboo problem. By using such a questionnaire, patients are given a secure feeling of anonymity. The final questionnaire consisted of 43 questions, which were reproducible, easy to understand, and applicable in an elderly, fairly independent population. The agreement with the urologist's medical history was $72 \%$, kappa was 0.66 (see chapter 3 ).

In chapter 4 the results of the questionnaire survey are described. Inhabitants $(\mathrm{N}=520)$ of 7 homes for the elderly were asked to participate in the questionnaire survey about lower urinary tract symptoms. The response rate was $79 \% ; 100$ male and 308 female residents. The mean age was 83 (range 56-102). Incontinence, defined as involuntary loss of urine on a daily basis, occurred in $17 \%$ of the males and $31 \%$ of the females. An urge component was involved in $62 \%$ of the males and $79 \%$ of the females. In case of incontinence, $75 \%$ of the males and $57 \%$ of the females consulted a physician, although only $56 \%$ and $38 \%$, respectively, felt burdened. From those who visited a physician, only $43 \%$ of the males and $13 \%$ of the females improved from treatment.

Generally it can be concluded that urinary incontinence has a high prevalence in elderly people and adequate therapy is often not given or asked for. This can be caused by lack of therapeutic means or by inadequate diagnosis. Since a lot of elderly people receive 'trial-and-error-treatment', it is meaningful to look for and evaluate diagnostic tools that are applicable in an elderly population. Since an urge component is often involved, it was decided to focus on bladder activity during the filling phase. The first step was to evaluate extramural ambulatory monitoring (EAM) in a group of elderly outpatients, followed by the development of a non-invasive tool.

EAM is known to be very sensitive with regard to detrusor activity and it can be applied outside the hospital. Chapter 5 describes the results of a study performed among 65 consecutive outpatients with lower urinary tract problems, who were sheduled for a urodynamic investigation. Subjectively, it was well tolerated and objectively, it was capable of assessing detrusor activity during the filling phase. The results also suggested that in elderly patients, who cannot come to the urodynamic laboratory, a non-invasive strategy to assess bladder function might be possible. 
The frequency/volume chart is a simple-to-use and low-cost tool which is often applied by general practitioners, urologists, gynaecologists and other workers in the field of lower urinary tract disorders to predict bladder activity. Frequency and functional bladder capacity can say something about urge and therefore bladder activity. In chapter 6 , the frequency/volume chart is calibrated against a full urodynamic workup, including ambulatory monitoring, in 216 female patients and 48 female volunteers. The statistical method used was backward stepwise logistic regression analysis. The BUS or behavioral urge score was developed: patients score on a $0-1$ interval, which expresses the severeness of the bladder overactivity. A nomogram was constructed, with which patients can be diagnosed with $90 \%$ sensitivity and specificity. Those who score between 0 and 0.42 can be regarded as having a non-overactive bladder, those who score between 0.73 and 1 as having an overactive bladder, and those who score in between need further evaluation/investigation. In about half of the investigated patients, invasive urodynamics could be avoided. The differentation between bladder overactivity and bladder non-overactivity by means of a frequency/volume chart is feasible and worthwhile.

The next step was to investigate whether the BUS is able to demonstrate improvement during therapy with bladder relaxing agents (see chapter 7). Patients were treated with emepronium carrageenate, oxybutynin chloride and placebo. Treatment with emepronium carrageenate showed a slight, statistically significant decrease in mean BUS value, compared to the initial, pre-treatment value. Treatment with oxybutynin chloride showed a more marked decrease. Placebo treatment did not show a statistically signficant change in mean BUS value.

In the future, results should be tested in the elderly population living independently at home or in institutional care. The results reported in the present thesis indicate that extramural ambulatory monitoring and non-invasive, low-cost investigations are possible and applicable in case of lower urinary tract complaints. Elderly patients might be diagnosed by simple methods:

- a thorough physical examination with stress testing to demonstrate a stress component;

- flowmetry with ultrasonic residue measurement to demonstrate outflow disorders;

- pad-testing to demonstrate incontinence;

- BUS to demonstrate detrusor overactivity and

- extramural ambulatory monitoring.

Further investigation in a urological or gynaecological outpatient clinic is necessary, only if these investigations do not yield a diagnosis, or if therapy does not produce the desired result. 


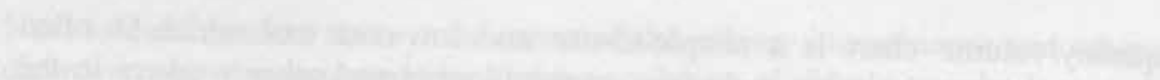

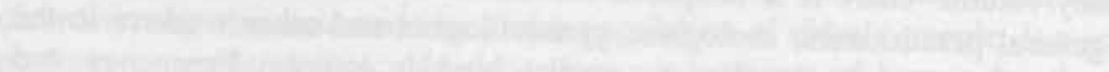

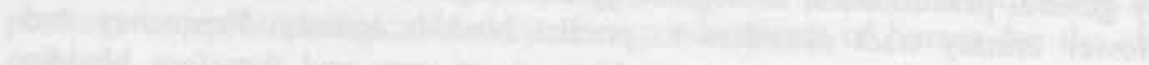

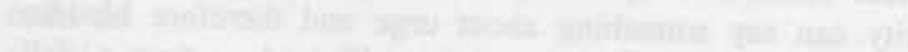
-

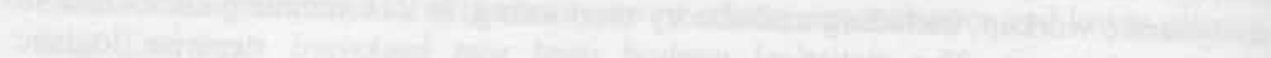

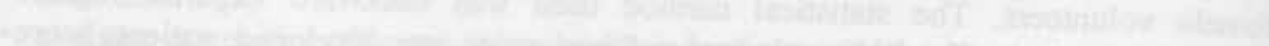
10. 15.

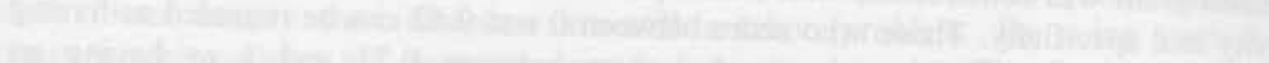

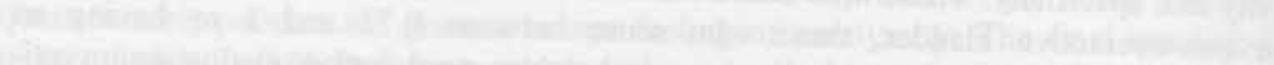
The The -

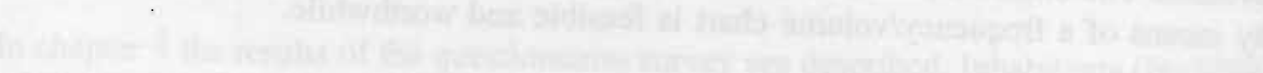
whing a

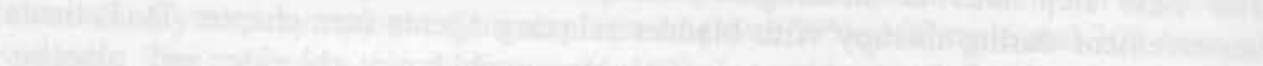

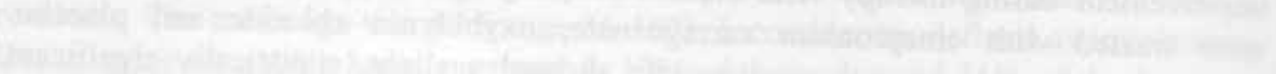

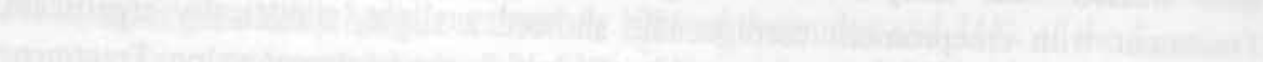
-

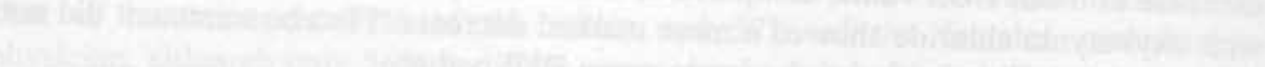

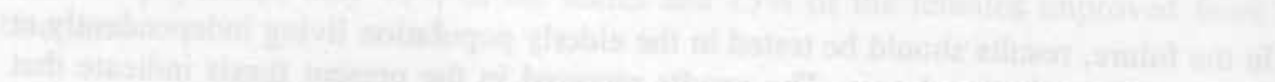

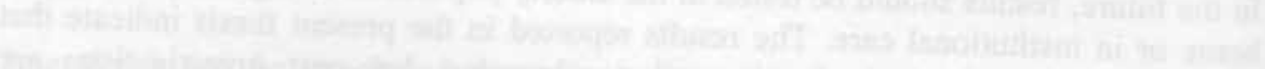

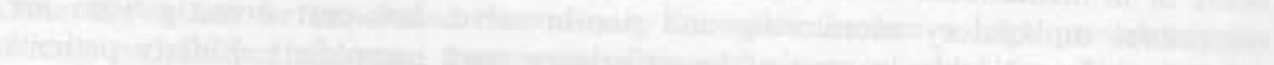

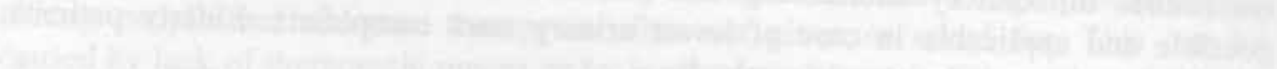

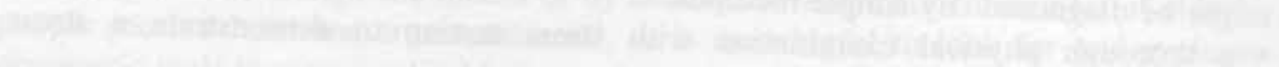
than

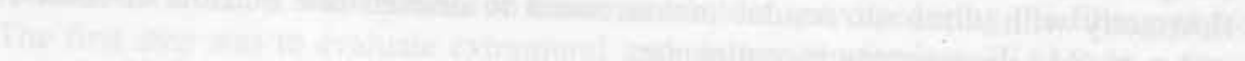

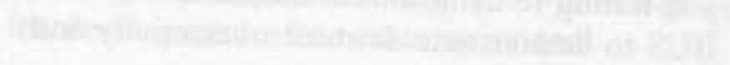

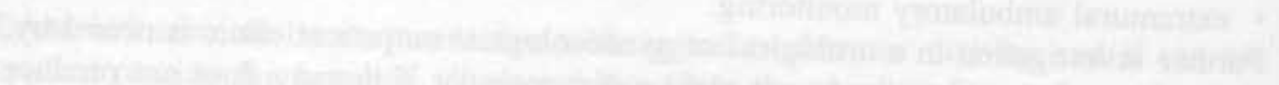

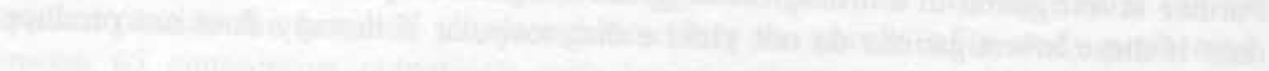




\section{SAMENVATTING}

\section{A. Remmers}

Afdeling Urologie, Academisch Ziekenhuis Maastricht 


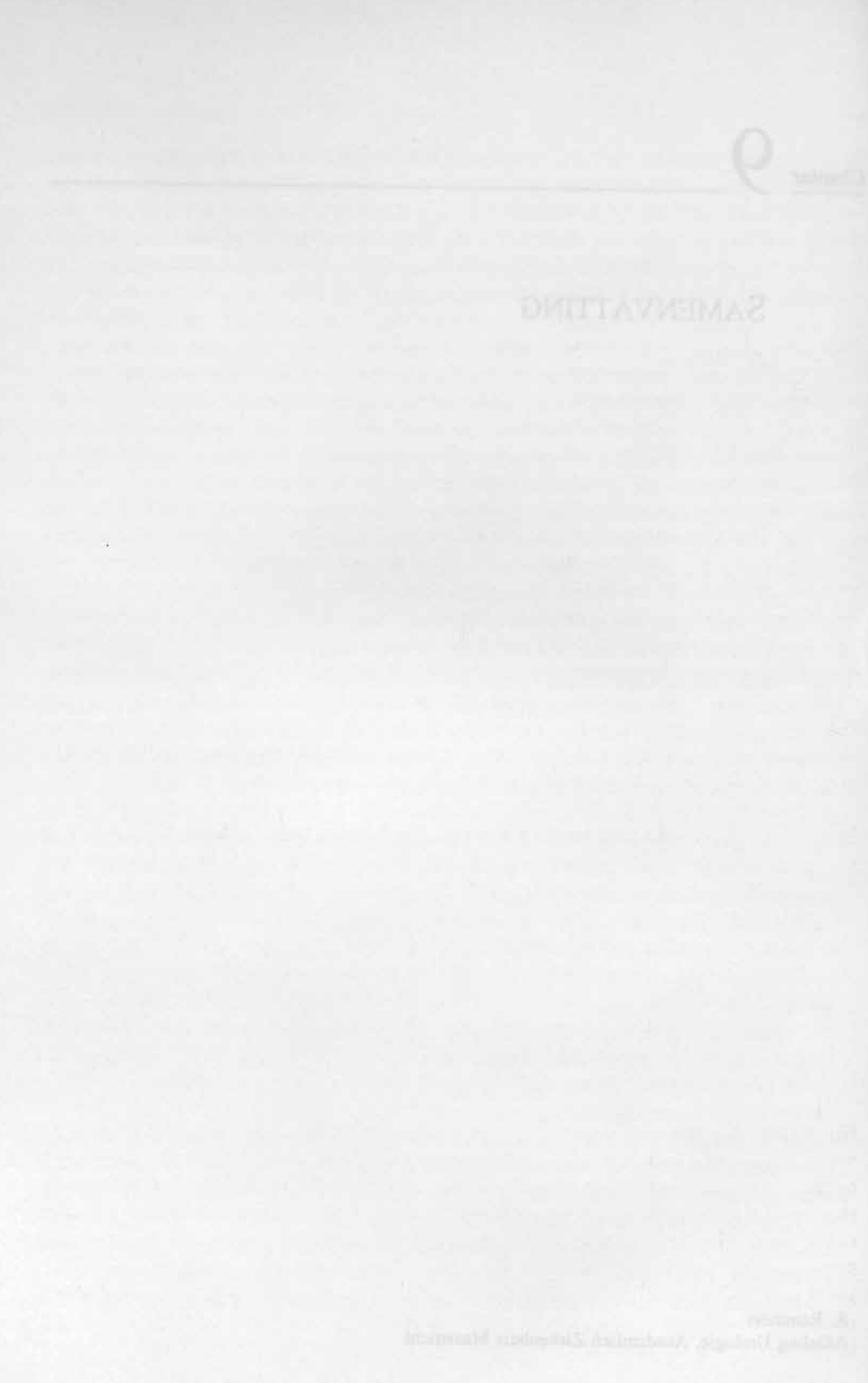


Lagere urinewegproblematiek, met name incontinentie, is een belangrijk chronisch gezondheidsprobleem voor velen. Alhoewel niet direct gerelateerd aan mortaliteit, heeft het zowel economische als sociale gevolgen. Sociale gevolgen zijn bijvoorbeeld, de angst voor onwillekeurig urineverlies, de angst een natte plek achter te laten op de bank van vrienden waar men op bezoek is, of de angst een onaangename geur te verspreiden. Een en ander kan leiden tot sociale isolatie. Economisch worden er door zowel patiënten als zorgverzekeraars kosten gemaakt, beiden spenderen grote sommen gelds aan luiers. Om deze redenen wordt door hulpverleners meer tijd en aandacht besteedt aan urine-incontinentie. Vooruitstrevende, dure en technisch hoogstaande onderzoeken en modellen worden ontwikkeld om het probleem te attaqueren en op te lossen.

Bij ouderen ligt het probleem anders, dezen melden zich niet altijd voor medische hulp en veronderstellen vaak dat incontinentie hoort bij het ouder worden. Gelukkig is deze houding aan het veranderen, dankzij het feit dat het onderwerp meer en gemakkelijker bespreekbaar is geworden. Een nadeel is, dat de kosten toenemen, veel ouderen bezoeken hun arts voor een recept voor luiers of luiers worden aan hen verstrekt via het verpleeg- of verzorgingstehuis waarin ze wonen. Een uitgebreid, technisch hoogstaand urodynamisch onderzoek is vaak niet toepasbaar in deze groep, vooral niet als er sprake is van hulpbehoevendheid ten gevolge van mentale en/of fysieke handicaps. In de toekomst zullen de kosten verder stijgen, meer mensen worden immers ouder en ouderen leven in het algemeen steeds langer.

De vraag rijst, of en hoe het probleem van lagere urinewegproblematiek, met name incontinentie, bij ouderen aangepakt kan worden in de nabije toekomst. Dit project is uitgevoerd om een bijdrage te leveren aan de oplossing van dit probleem.

Hoofdstuk 1 geeft een introductie waarin de formulering van de doelen:

- het bestuderen van de epidemiologie van lagere urinewegproblematiek bij ouderen:

a. in de literatuur;

b. bij bewoners van verzorgingstehuizen;

- de evaluatie van extramuraal ambulant urodynamisch onderzoek, een relatief eenvoudig diagnostisch hulpmiddel, in een groep poliklinische patiënten van 60 jaar en ouder;

- de ontwikkeling van een eenvoudig, niet-invasief diagnostisch middel om blaasactiviteit kwalitatief en kwantitatief te scoren, gebaseerd op een plas- en drinkdagboek.

Hoofdstuk 2 geeft een overzicht van de internationale literatuur betreffende de prevalentie van urine-incontinentie en andere lagere urinewegproblematiek bij ouderen. De exacte prevalentie van incontinentie is niet te achterhalen: de besproken studies zijn gedaan in verschillende populaties met verschillende methoden van data collectie en bij gebruik van verschillende definities van urine-incontinentie. Indien de studies worden gecategorizeerd naar populatie, informatie bron en definitie, dan kan geconcludeerd worden dat de prevalentie van urine-incontinentie rond de $20 \%$ ligt bij oudere mannen en rond de $35 \%$ bij oudere vrouwen ( 60 jaar en ouder). Het verschil in prevalentie tussen mannen en vrouwen wordt mogelijk veroorzaakt doordat stress 
incontinentie vrijwel alleen bij vrouwen voorkomt. Bij ongeveer $80 \%$ van de incontinenten is er sprake van een urge component.

De prevalentie van urine-incontinentie en andere mictieproblemen is eveneens onderzocht in een Nederlandse oudere populatie. Er was gekozen om een epidemiologische studie uit te voeren onder bewoners van verzorgingshuizen, om:

- de prevalentie en de ernst van de urine-incontinentie te schatten;

- de prevalentie van de verschillende typen incontinentie en lagere urinewegproblemen te schatten;

- afwijkingen die vaak geassocieerd worden met incontinentie te evalueren en

- de last die de patiënt ervaart t.g.v. de incontinentie te evalueren.

Hiertoe werd een vragenlijst ontwikkeld. Er is besloten een schriftelijke lijst te ontwikkelen, opdat de respondent anoniem kan blijven. De uiteindelijke vragenlijst bestond uit 43 vragen, die reproduceerbaar waren, gemakkelijk te begrijpen en toepasbaar in een oudere, redelijk onafhankelijke populatie. De overeenstemming met de anamnese van de uroloog was $72 \%$, kappa was 0.66 (zie hoofdstuk 3 ).

In hoofdstuk 4 zijn de resultaten van het epidemiologische onderzoek beschreven. Aan 520 bewoners van 7 verzorgingshuizen is gevraagd deel te nemen aan het onderzoek. De respons was $79 \%, 100$ mannen en 308 vrouwen. De gemiddelde leeftijd was 83 (56-102) jaar. Incontinentie, gedefinieerd als dagelijks onwillekeurig urineverlies, werd gerapporteerd door $17 \%$ van de mannen en $31 \%$ van de vrouwen. Bij $62 \%$ van de mannen en $79 \%$ van de vrouwen was er sprake van een urge component. Van diegenen die incontinent waren, bezocht $75 \%$ van de mannen en $57 \%$ van de vrouwen een arts, hoewel slechts respectievelijk $56 \%$ en $38 \%$ de incontinentie als klacht ervoer en/of zich beperkt voelde. Van diegenen die een arts bezochtten en behandeld werden, verbeterde $43 \%$ van de mannen en slechts $13 \%$ van de vrouwen.

Geconcludeerd kan worden dat urine-incontinentie veelvuldig voorkomt bij ouderen en dat adekwate therapie vaak niet geboden of gevraagd wordt. Dit kan veroorzaakt worden door ofwel een gebrek aan therapeutische opties ofwel onvoldoende diagnostiek. Omdat vele ouderen 'trial-and-error' behandeling krijgen, is het interessant diagnostische middelen, die toepasbaar zijn in een oudere populatie te evalueren. In eerste instantie wordt de diagnostiek m.b.t. urge geëvalueerd, omdat een urge component veelvuldig een rol lijkt te spelen in de incontinentie. De eerste stap bestond uit het evalueren van het extramurale ambulante urodynamische onderzoek in een groep oudere patiënten, gevolgd door de ontwikkeling van niet-invasieve urodynamica.

Van het ambulante onderzoek is bekend dat het erg sensitief is wat betreft blaasactiviteit en dat het toepasbaar is buiten het ziekenhuis. Hoofdstuk 5 beschrijft de resultaten van een studie die uitgevoerd is bij 65 oudere poliklinische patiënten met lagere urineweg problematiek, die allen een urodynamisch onderzoek ondergingen. Subjectief werd het ambulante onderzoek goed verdragen en objectief was het 
in staat blaasactiviteit tijdens de vullingsfase te diagnostiseren. De resultaten suggereerden ook dat een niet-invasieve strategie tot de mogelijkheden behoort bij oudere patiënten, die niet naar het urodynamische laboratorium kunnen of willen komen.

Het urologische plas- en drinkdagboek is een eenvoudig en goedkoop hulpmiddel, dat vaak gebruikt wordt door huisartsen, urologen, gynaecologen en anderen die zich met lagere urinewegproblematiek bezighouden, om blaasactiviteit te voorspellen. Frequency en functionele blaascapaciteit zeggen iets over de urge en daarmee over blaasactiviteit. In hoofdstuk 6 werd het plas- en drinkdagboek gecalibreerd tegen een compleet urodynamisch onderzoek (inclusief het ambulante onderzoek) bij 216 vrouwelijke patiënten en 48 vrouwelijke vrijwilligers. Hiertoe werd gebruik gemaakt van 'backward stepwise' logistische regressie analyse. De BUS (behavioral urge score) werd ontwikkeld: patiënten scoorden op een 0-1 interval, wat de ernst van de blaas (over)activiteit weergeeft. Vervolgens werd een nomogram gemaakt, waarmee patiënten met lagere urinewegklachten met een sensitiviteit en specificiteit van $90 \%$ gediagnostiseerd kunnen worden. Diegenen die dan tussen de 0 en de 0.42 scoren, hebben een niet-overactieve blaas. Diegenen die tussen de 0.73 en de 1 scoren, een overactieve blaas en de overige patiënten behoeven dan nadere diagnostiek. In ongeveer de helft van de onderzochte populatie kon op deze manier invasief onderzoek vermeden worden. De differentiatie tussen wel of geen blaas overactiviteit m.b.v. een plas- en drinkdagboek lijkt uitvoerbaar en waardevol.

De volgende stap was te onderzoeken of de BUS in staat is verbetering t.g.v. behandeling met blaasrelaxantia te detecteren (zie hoofdstuk 7). Dit om iets te kunnen zeggen over de validiteit van de BUS. Patiënten werden behandeld met emepronium carrageenaat, oxybutynine chloride en placebo. Behandeling met emepronium liet een lichte, statistisch significante daling zien van de gemiddelde BUS. Behandeling met oxybutynine liet een meer uitgesproken daling zien. Placebo behandeling gaf geen verandering in gemiddelde BUS.

In de toekomst zullen de beschreven resultaten getest moeten worden in een oudere populatie. De hier beschreven resultaten geven aan dat non-invasieve, goedkope onderzoeken mogelijk en toepasbaar zijn in het geval van lagere urinewegklachten. Oudere patiënten zouden onderzocht kunnen worden m.b.v. eenvoudige diagnostiek:

- een grondig lichamelijk onderzoek met stresstest om een stress component te objectiveren;

- flowmetrie met echografische bepaling van residu om outflow problemen te objectiveren;

- pad-test om incontinentie te objectiveren en

- BUS om detrusor overactiviteit te objectiveren.

Nader onderzoek in een urologische of gynaecologische praktijk is alleen dan noodzakelijk, als bovengenoemde onderzoeken niet leiden tot een diagnose of als de ingestelde therapie onvoldoende verbetering geeft. 


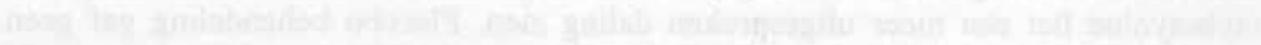

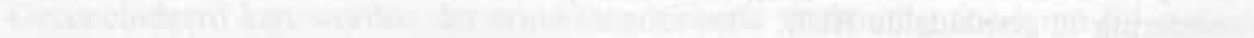

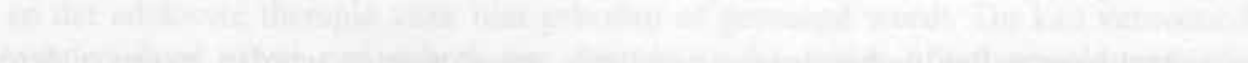
ant

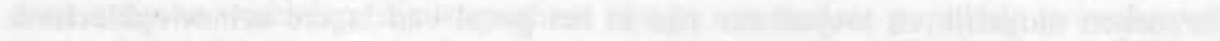

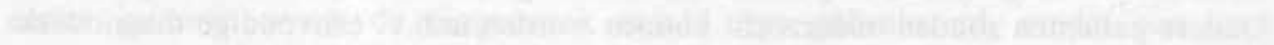

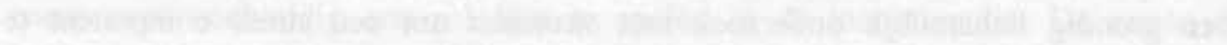
ran

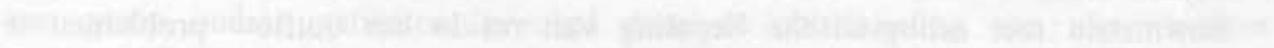

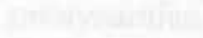

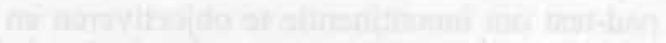

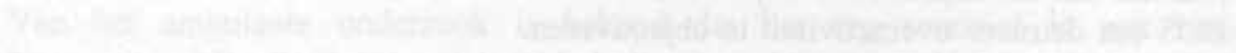

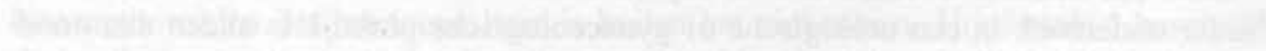

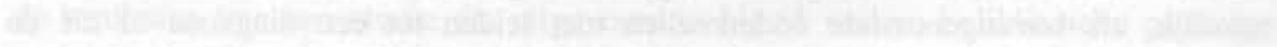

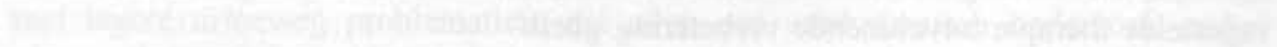

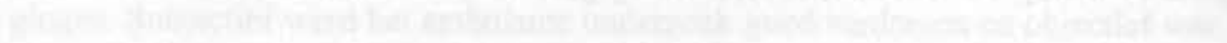




\section{Appendix A}

Overview of selected urinary incontinence prevalence studies in elderly people

\section{Studies in community settings and institutions}

prevalence (\%)

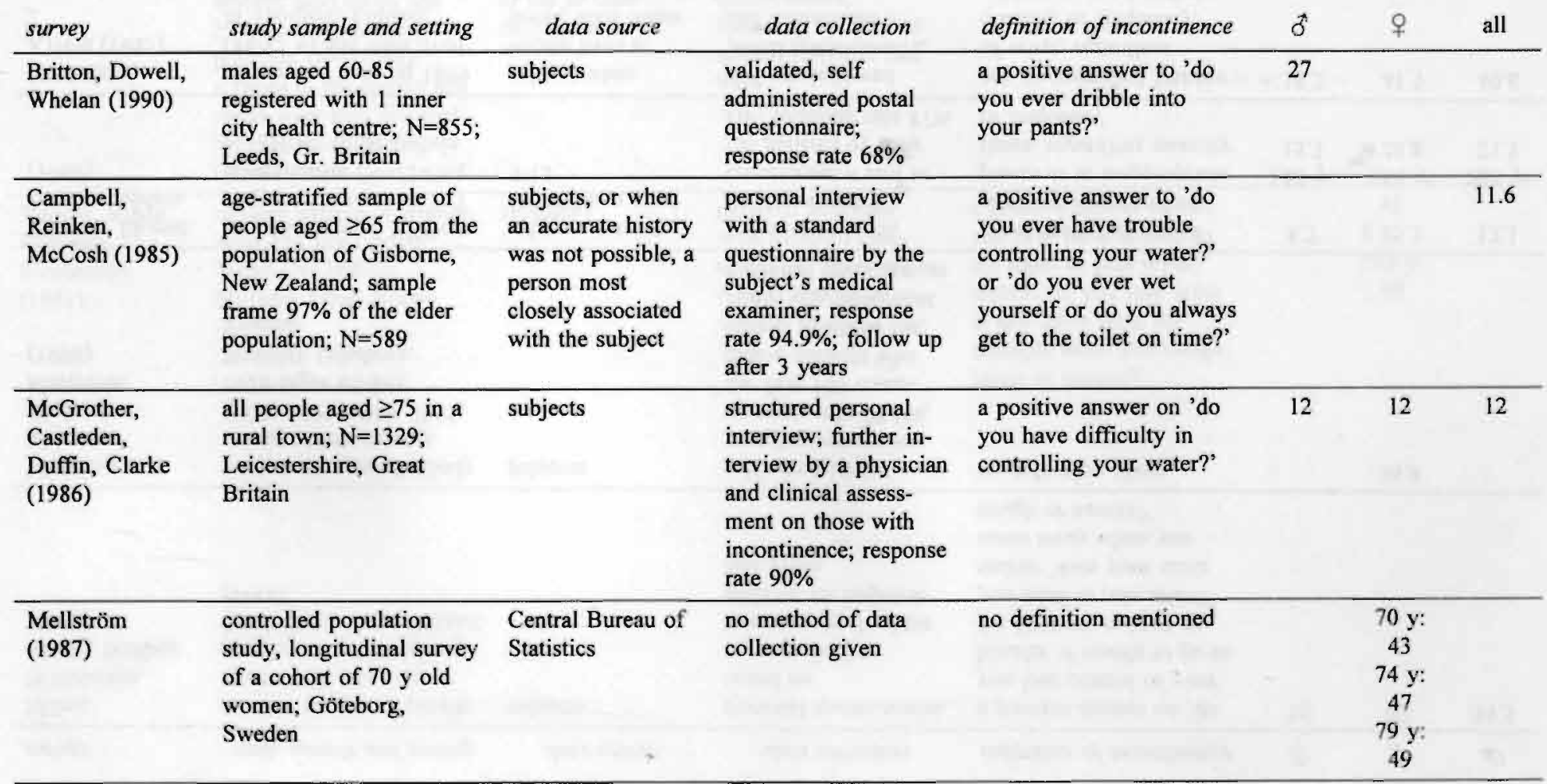




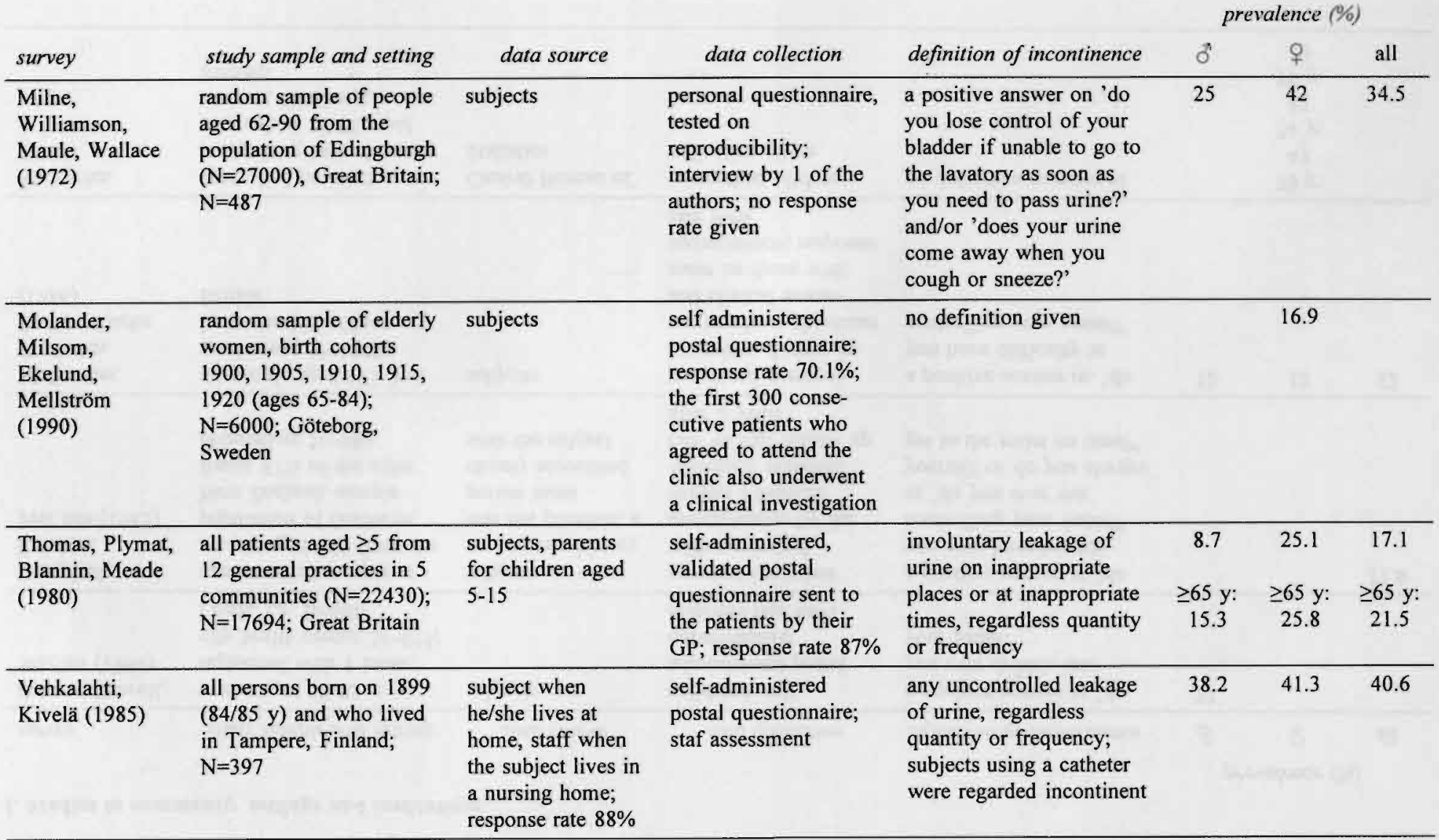




\begin{tabular}{|c|c|c|c|c|c|c|c|}
\hline \multirow{2}{*}{$\begin{array}{l}\text { survey } \\
\text { Yarnell, St. } \\
\text { Leger (1979) }\end{array}$} & \multirow{5}{*}{\begin{tabular}{l}
\multicolumn{1}{c}{ study sample and setting } \\
random sample of men \\
aged $65 / 66$ and $\geq 70$ and \\
women aged $65 / 66$ and \\
$\geq 75$ from all medical \\
practices ( $N=27696$ ), dai \\
spouses in the correct age \\
range were also included; \\
$N=396 ;$ South Wales, \\
Great Britain
\end{tabular}} & \multirow{4}{*}{\begin{tabular}{l}
\multicolumn{1}{c}{ data source } \\
subject, if mentally \\
deteriorated: next \\
of kin or other \\
daily attendant
\end{tabular}} & \multirow{4}{*}{$\begin{array}{l}\quad \text { data collection } \\
\text { personal interview } \\
\text { with a standard } \\
\text { questionnaire, } \\
\text { interview by the first } \\
\text { author; response rate } \\
98 \%\end{array}$} & \multirow{3}{*}{$\begin{array}{l}\text { definition of incontinence } \\
\text { any leakage of urine in } \\
\text { the past } 12 \text { months }\end{array}$} & \multicolumn{3}{|c|}{ prevalence (\%) } \\
\hline & & & & & \multirow{2}{*}{$\frac{\sigma^{t}}{11}$} & \multirow{2}{*}{$\frac{q}{17}$} & \multirow{2}{*}{$\frac{\text { all }}{14}$} \\
\hline & & & & & & & \\
\hline 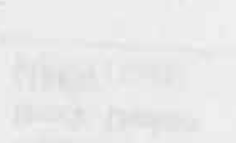 & & & & & & & \\
\hline Yamell, Voyle, & & & & & & 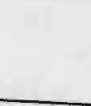 & \\
\hline $\begin{array}{l}\text { Richards, } \\
\text { Stephenson } \\
\text { (1981) }\end{array}$ & $\begin{array}{l}\text { random sample of women } \\
\text { aged } \geq 16 \text { from South } \\
\text { Wales }(N=38000) \text {; }\end{array}$ & subjects & $\begin{array}{l}\text { personal interview } \\
\text { with standard ques- } \\
\text { tionnaire }\end{array}$ & $\begin{array}{l}\text { a positive answer on 'do } \\
\text { you ever have to rush to }\end{array}$ & & 45 & \\
\hline 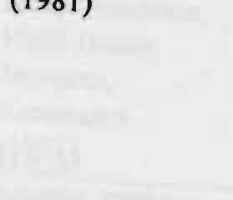 & $N=1060 ;$ Great Britain & & $\begin{array}{l}\text { tIonnaire, interview by } \\
\text { trained female inter- } \\
\text { viewer; response rate } \\
95 \%\end{array}$ & $\begin{array}{l}\text { the toilet to pass water?' } \\
\text { and/or 'do you lose urine } \\
\text { at any other time, for } \\
\text { example when you cough, } \\
\text { laugh or sneeze?' }\end{array}$ & & $\begin{array}{l}\geq 65 y: \\
49\end{array}$ & \\
\hline
\end{tabular}




\begin{tabular}{|c|c|c|c|c|c|c|c|}
\hline \multirow[b]{2}{*}{ survey } & \multirow[b]{2}{*}{ study sample and setting } & \multirow[b]{2}{*}{ data source } & \multirow[b]{2}{*}{ data collection } & \multirow[b]{2}{*}{ definition of incontinence } & \multicolumn{3}{|c|}{ prevalence (\%) } \\
\hline & & & & & $\delta$ & q & all \\
\hline $\begin{array}{l}\text { Diokno, Brock, } \\
\text { Brown, Herzog } \\
(1986)\end{array}$ & $\begin{array}{l}\text { multi-stage probability } \\
\text { sample from Washtenaw } \\
\text { County, Michigan, US } \\
(\mathrm{N}=13912 \text { house-holds), } \\
\text { only persons aged } \geq 60 \\
\text { were included; } \mathrm{N}=3005\end{array}$ & subjects & $\begin{array}{l}\text { personal interview } \\
\text { with a standard } \\
\text { questionnaire, } \\
\text { interview by trained } \\
\text { interviewers; response } \\
\text { rate } 65.1 \%\end{array}$ & $\begin{array}{l}\text { any amount of urine loss } \\
\text { with a minimum } \\
\text { frequency of } 6 \text { days in } \\
\text { the past } 12 \text { months }\end{array}$ & 18.9 & 37.7 & 30.0 \\
\hline $\begin{array}{l}\text { Feneley, } \\
\text { Shepherd, } \\
\text { Powell, Blannin } \\
\text { (1979) }\end{array}$ & $\begin{array}{l}\text { all patients in a group } \\
\text { practice in Avon, Great } \\
\text { Britain; } N=7000\end{array}$ & $\begin{array}{l}\text { subjects; parents in } \\
\text { case of subjects } \\
\text { aged } 5-15\end{array}$ & $\begin{array}{l}\text { self-adminsitered } \\
\text { postal questionnaire; } \\
\text { response rate } 93 \%\end{array}$ & $\begin{array}{l}\text { involuntary leakage of } \\
\text { urine in inappropriate } \\
\text { places and at inappro- } \\
\text { priate times; either } \\
\text { dribbling inc. or } \geq 2 \text { epi- } \\
\text { sodes of incontinence in } \\
\text { the previous month, } \\
\text { inclusion of those treated } \\
\text { with catheters or } \\
\text { appliances }\end{array}$ & $\begin{aligned} & 3.3 \\
\geq & 65 \mathrm{y}: \\
& 5.7\end{aligned}$ & $\begin{aligned} & 8.0 \\
& \geq 65 y \\
& 13.9\end{aligned}$ & 5.4 \\
\hline $\begin{array}{l}\text { Herzog, Fultz, } \\
\text { Normolle, } \\
\text { Brock, Diokno } \\
\text { (1989) }\end{array}$ & $\begin{array}{l}\text { multi-stage stratified area- } \\
\text { probability sample from } \\
\text { Washtenaw County, US } \\
(\mathrm{N}=13912 \text { households), }\end{array}$ & subjects & $\begin{array}{l}\text { personal interview } \\
\text { with a standard } \\
\text { questionnaire, } \\
\text { interview by trained }\end{array}$ & $\begin{array}{l}\text { any amount of urine loss } \\
\text { with a minimum } \\
\text { frequency of } 6 \text { days in } \\
\text { the past } 12 \text { months }\end{array}$ & 19 & 38 & 30 \\
\hline & $\begin{array}{l}\text { only persons aged } \geq 60 \\
\text { were included; } N=2993\end{array}$ & & $\begin{array}{l}\text { interviewers; response } \\
\text { rate } 65 \% \text {; clinical } \\
\text { investigation on a } \\
\text { subset of respondents }\end{array}$ & & 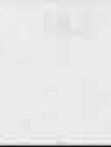 & 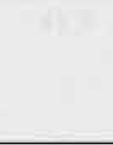 & \\
\hline $\begin{array}{l}\text { Holst, Wilson } \\
\text { (1988) }\end{array}$ & $\begin{array}{l}\text { random sample of } \\
\text { women; } N=1125 ;\end{array}$ & $\begin{array}{l}\text { subjects, } 6 \\
\text { interviews were }\end{array}$ & $\begin{array}{l}\text { telephone interview } \\
\text { with a standard }\end{array}$ & $\begin{array}{l}\text { involuntary leakage of } \\
\text { urine in the past } 12\end{array}$ & & 31.4 & \\
\hline 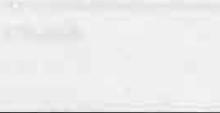 & Dunedin, New Zealand & $\begin{array}{l}\text { with primary } \\
\text { caregivers }\end{array}$ & $\begin{array}{l}\text { questionnaire by } 1 \text { of } \\
\text { the authors; response } \\
\text { rate } 75.6 \%\end{array}$ & $\begin{array}{l}\text { months, regardless } \\
\text { frequency or amount }\end{array}$ & & $\begin{array}{l}\geq 65 \mathrm{y}: \\
34.3\end{array}$ & 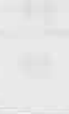 \\
\hline
\end{tabular}




\begin{tabular}{|c|c|c|c|c|c|c|c|}
\hline survey & study sample and setting & data source & data collection & definition of incontinence & $\hat{\delta}$ & $q$ & all \\
\hline $\begin{array}{l}\text { Jagger, Clarke, } \\
\text { Davies (1986) }\end{array}$ & $\begin{array}{l}\text { all patients aged } \geq 75 \text { in a } \\
12 \text {-doctor general prac- } \\
\text { tice; } N=1329 ; \\
\text { Leicestershire, Great } \\
\text { Britain }\end{array}$ & subjects & $\begin{array}{l}\text { personal interview } \\
\text { with a standard } \\
\text { questionnaire, type of } \\
\text { interviewer is not } \\
\text { mentioned; response } \\
\text { rate } 80.7 \%\end{array}$ & $\begin{array}{l}\text { a postitive answer on: 'do } \\
\text { you have any difficulty } \\
\text { controlling your water?'; } \\
\text { patients with appliances } \\
\text { were considered as a } \\
\text { seperate group }\end{array}$ & & & 9.2 \\
\hline Jolleys (1988) & $\begin{array}{l}\text { all women in a rural } \\
\text { general practice aged } \geq 25 \\
\text { and } 30 \text { women aged }<21 \\
\text { taking oral contracep- } \\
\text { tives; } \mathrm{N}=937 \text { : Leicester- } \\
\text { shire, Great Britain }\end{array}$ & subjects & $\begin{array}{l}\text { self-administered } \\
\text { postal questionnaire; } \\
\text { response rate } 89 \%\end{array}$ & $\begin{array}{l}\text { any inappropriate leakage } \\
\text { of urine }\end{array}$ & & $\begin{array}{c}41 \\
\geq 65 y: \\
25\end{array}$ & \\
\hline $\begin{array}{l}\text { Kok, Voorhorst, } \\
\text { Halff-Butter, } \\
\text { Janssens, } \\
\text { Kenemans } \\
\text { (1991) }\end{array}$ & $\begin{array}{l}\text { age-stratified random } \\
\text { sample of women aged } \\
\geq 60(\mathrm{~N}=8967) ; \mathrm{N}=1049 ; \\
\text { Amstelveen, The } \\
\text { Netherlands }\end{array}$ & subjects & $\begin{array}{l}\text { self-administered } \\
\text { postal questionnaire; } \\
\text { response rate } 69 \%\end{array}$ & $\begin{array}{l}\text { urine loss } \geq 2 \text { times per } \\
\text { week, regardless the } \\
\text { amount of loss }\end{array}$ & & 23.4 & \\
\hline Noelker (1987) & $\begin{array}{l}\text { persons aged } \geq 60 \text { living } \\
\text { with spouse or adult child } \\
\text { who helped with } 1 \text { or } \\
\text { more personal care tasks; } \\
\mathrm{N}=614 \text {; (senior) organiza- } \\
\text { tions in the Greater } \\
\text { Cleveland metropolitan } \\
\text { area and } 10 \text { nonmetro- } \\
\text { politan counties. USA }\end{array}$ & primary caregiver & $\begin{array}{l}\text { personal interview } \\
\text { with a standard } \\
\text { questionnaire; the type } \\
\text { of interviewer is not } \\
\text { mentioned; response } \\
\text { rate } 85 \%\end{array}$ & $\begin{array}{l}\text { a positive answer on } \\
\text { 'does your (elder) have } \\
\text { any problem controlling } \\
\text { his/her urine?' }\end{array}$ & 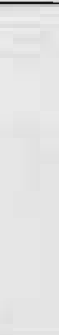 & & 53 \\
\hline
\end{tabular}




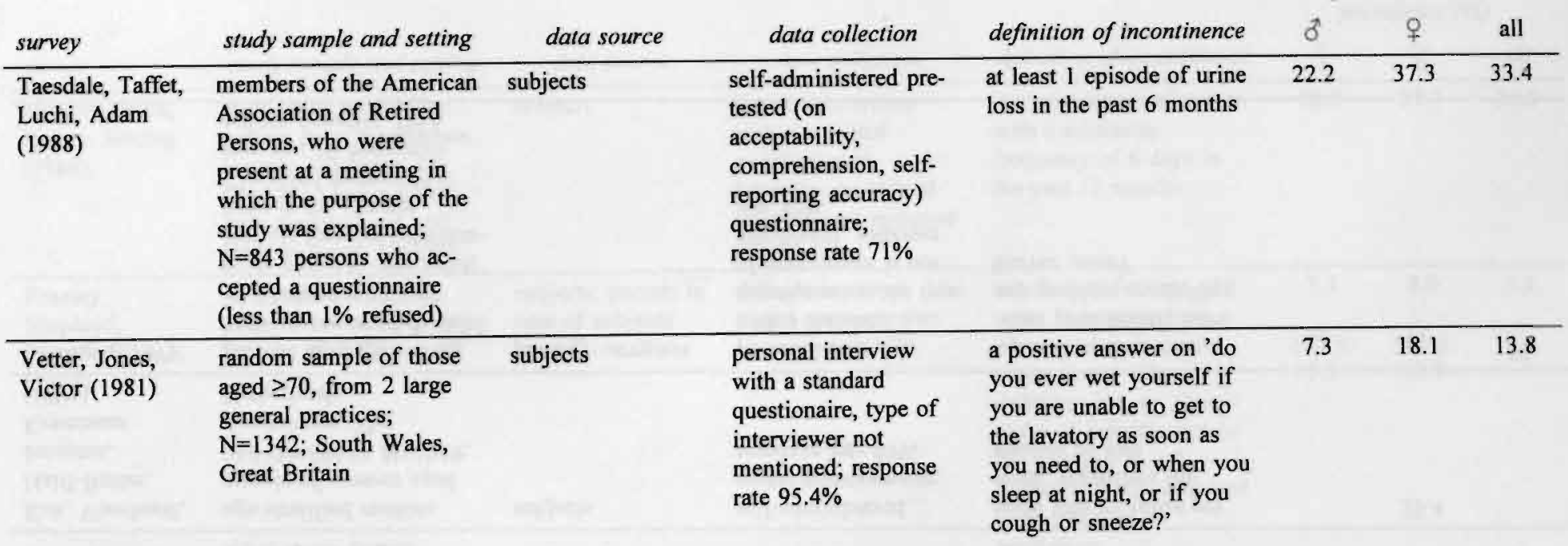




\section{Studies in institutions only}

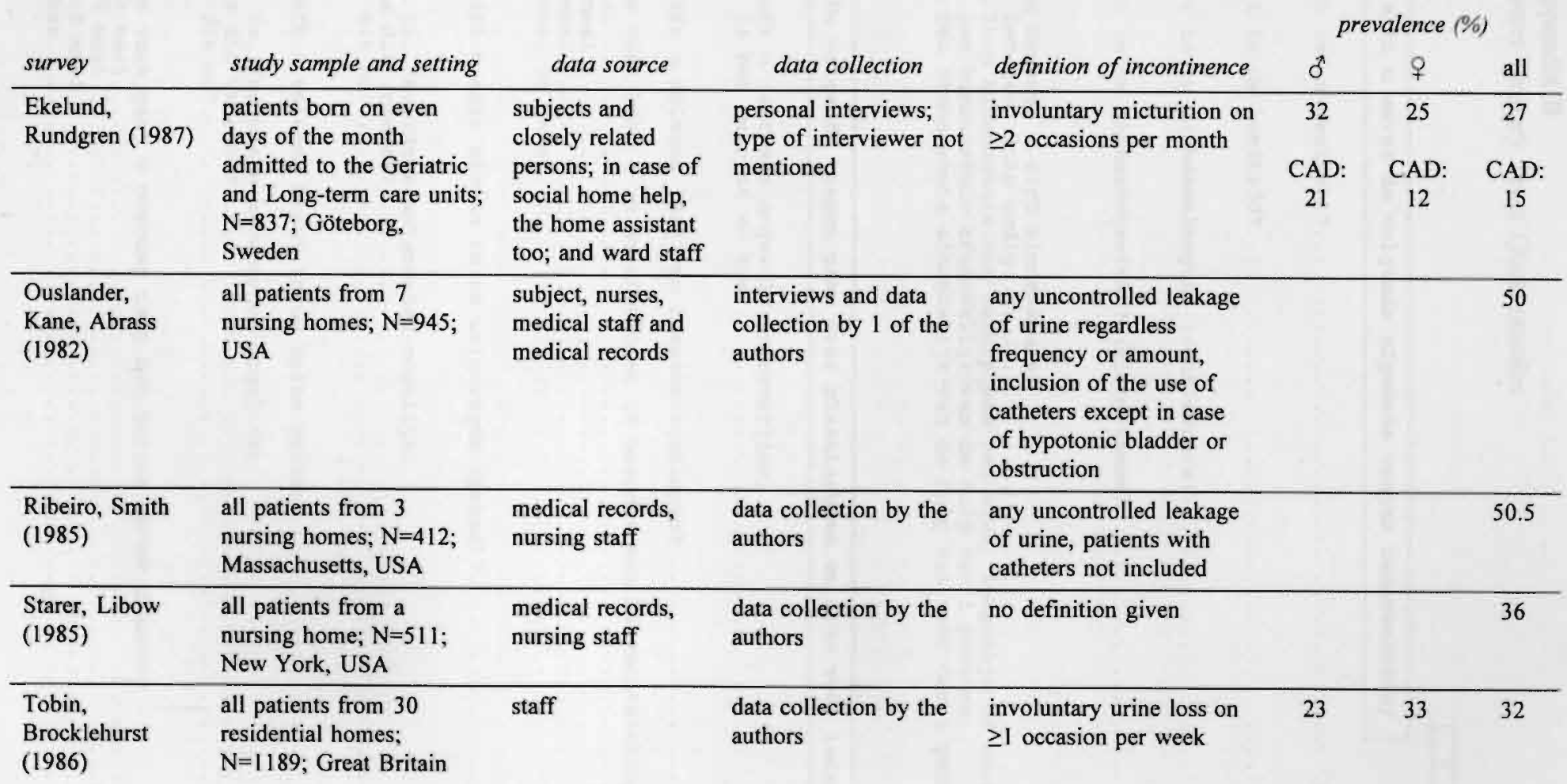



Appendix B

Lower Urinary Tract Questionnaire

Wilt u eerst de volgende algemene vragen beantwoorden?

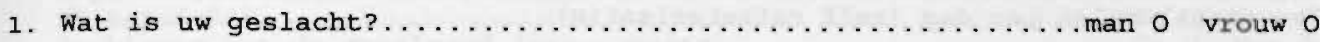

2. Wat is uw leeftijd? ...........................

3. Wat is uw lichaamslengte? (centimeters) $\ldots \ldots \ldots \ldots \ldots \ldots \ldots \ldots \ldots \ldots$

4. Wat is uw lichaamsgewicht? (kilogrammen).

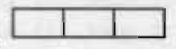

5. Hoe beweegt u zich binnenshuis?

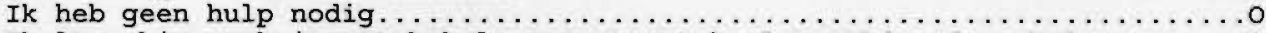

Ik loop binnenshuis met behulp van een stok, looprekje of meubels.......

Ik ben binnenshuis afhankelijk van de hulp van 1 persoon.............

Ik ben binnenshuis afhankelijk van de hulp van meer dan 1 persoon.......

De volgende vragen gaan over plasklachten en zijn voor iedereen

6. Heeft u last van ongewild urineverlies,

al is het maar af en toe?.............................. o Nee 0

7. Heeft $u$ weleens last van blaasontstekingen?..............Ja 0 Nee 0

Hoe vaak hebt $\mathrm{u}$ in de afgelopen 12 maanden een blaasontsteking gehad?

Niet. . . . . . . . . . . . . . . . . . . . . . . . . . . . . . . .

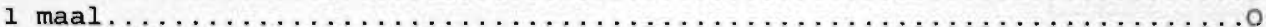

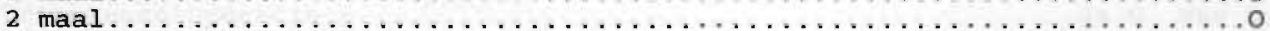

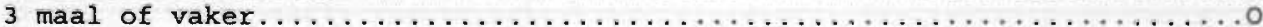

8. Heeft $u$ ooit stenen in uw urinewegen (gehad) ?.............. Ja 0 Nes 0

Zo ja: (meerdere antwoorden mogelijk)

Was dit vroeger? . . . . . . . . . . . . . . . . . . . . . . .

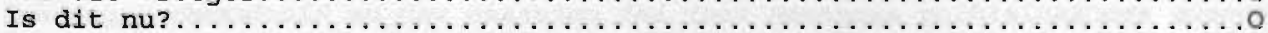

9. Heeft $u$ weleens bloed in uw urine gezien?................ Ja o Nee o

Zo ja, (meerdere antwoorden mogelijk)

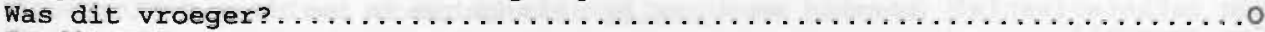

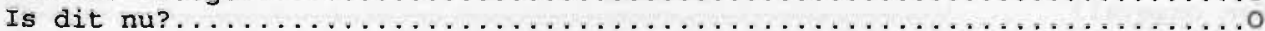

10. Hoe vaak gaat $u$ overdag naar het toilet om te plassen?

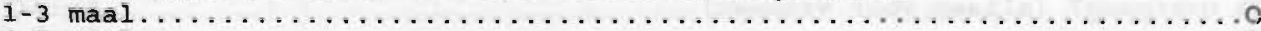

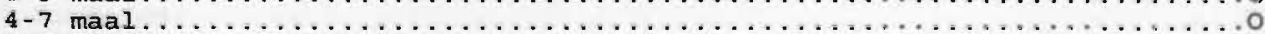

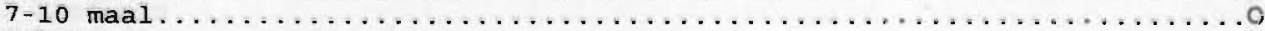

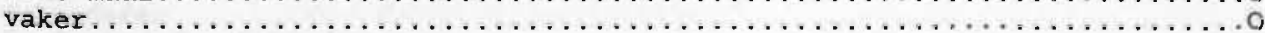


11. Hoe vaak gaat $u$ 's nachts naar het toilet om te plassen?

Nooit. . . . . . . . . . . . . . . . . . . . . . . . . . . . . . . . . . . .

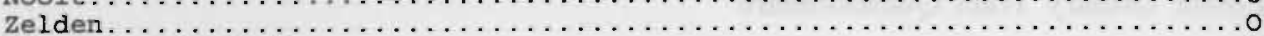

Eén keer per nacht. . . . . . . . . . . . . . . . . . . . . . . . . . . . .

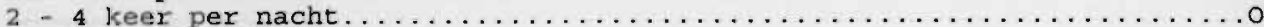

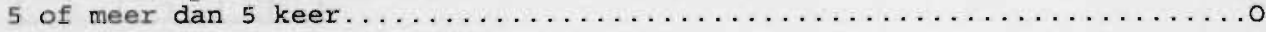

12. Gebruikt u een catheter?

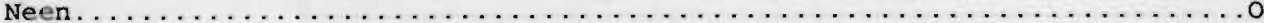

Voortdurend. . . . . . . . . . . . . . . . . . . . . . . . . . . . . .

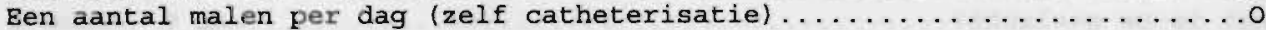

Indien $u$ een catheter gebruikt, warom is dit nodig?

Ondat mijn plas niet vanzelf wil komen. . . . . . . . . . . . . . . . . .

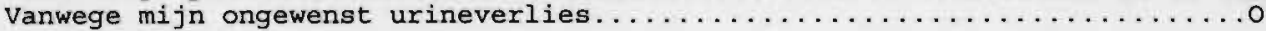

13. Moet $u$ haast maken om het toilet op tijd te bereiken?........Ja o Nee o

14. Kunt $u$ met een krachtige straal plassen?.........Wisselend $\mathrm{O}$ Ja $\mathrm{O}$ Nee $\mathrm{O}$

Zo neen (alleen voor mannen), is de straal de laatste jaren

duidelijk verminderd?............................... Ja o Nee o

15. Moet $u$, als u gaat plassen, wachten voordat de plas op gang

komt? (alleen voor mannen)................................ Na Nee o

16. Verliest $u$ weleens wat uxine net na het plassen? (nadruppelen)..Ja 0 Nee $O$

Is dit dan:

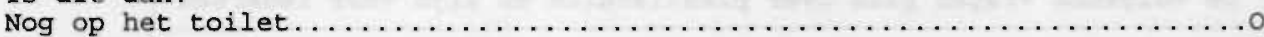

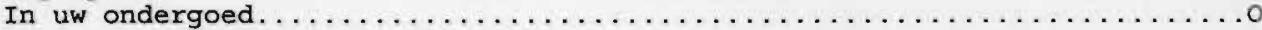

17. Moet u persen op uw plas?........................ Ja o Nee o

18. Ervaart $u$ op dit moment klachten met betrekking tot het

plassen?......................................Ja o Nee o

Indien $u$ op vraag 18 NEB heeft geantwoord, kunt $u$ verder gaan met vraag 21. Heeft $u$ JA ingevuld, beantwoord dan ook vraag 19 en 20

19. Hoe oud was $\mathrm{u}$ toen uw klachten begonnen?.

20. Kunt $u$ een aanleiding aangeven voor het ontstaan van uw klachten? Wilt $u$ aankruisen wat voor u van toepassing is?

(meerdere antwoorden mogelijk)

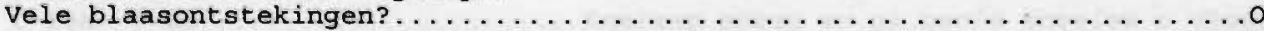

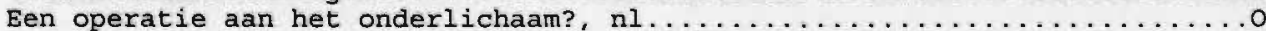

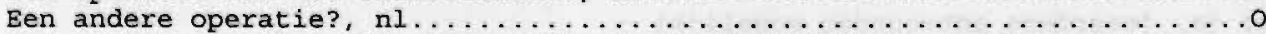

Een catheterisatie? (hierbij wordt er een slangetje in uw blaas gestopt)...

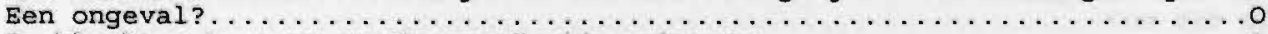

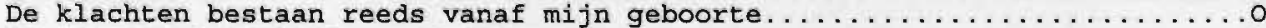

Er is geen duidelijke aanleiding. . . . . . . . . . . . . . . . . . . .

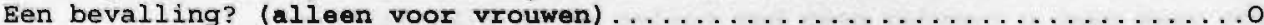

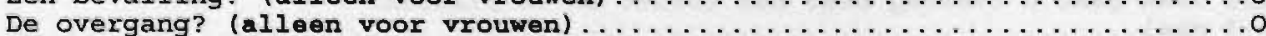




\section{De volgende vragen zijn weer voor IEDEREEN}

21. Heeft $u$ één of meerdere van de volgende ziekten of problemen? (meerdere Ja-antwoorden mogelijk)

Geregeld ontstekingen in de schede (afscheiding) (vrouwen).....Ja o Nee o ontstekingen aan het urinekanaal (afscheiding) (mannen).........Ja O Nee O

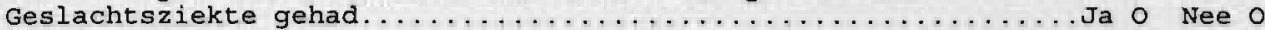

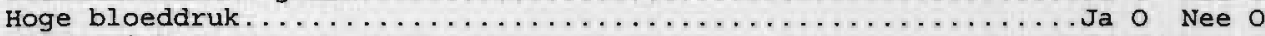
Suikerziekte...................................... Ja o Nee o Problemen met de stoelgang (verstopping)..................Ja o Nee 0 ongewild verlies van ontlasting........................... 0 . Nee 0

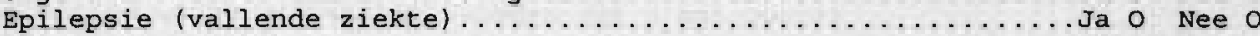

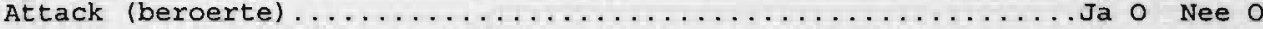

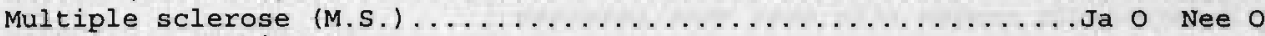

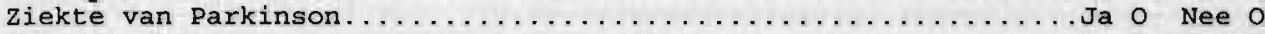

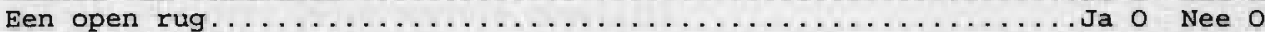

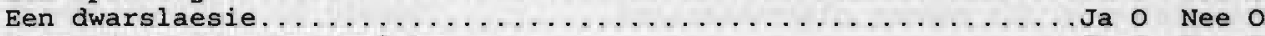

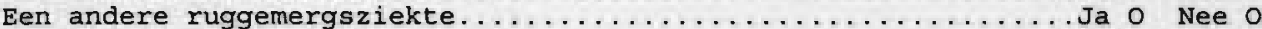

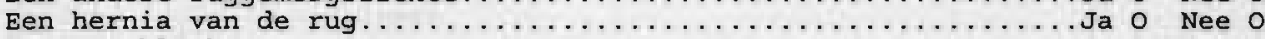

Lage rugklachten................................. Ja o Nee o

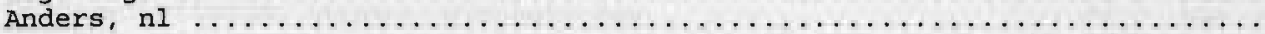

22. Heeft $u$ op latere leeftijd een onderlichaams-, buik-

of rugoperatie ondergaan?...................... Weet ik niet o Ja o Nee 0

zo ja, heeft u één of meerdere van de volgende operaties ondergaan?

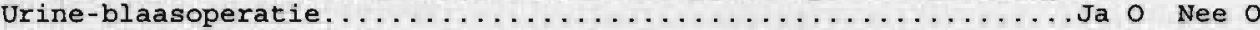

Zo ja, in welk jaar?.........................

Baarmoeder-verwijdering (vrouwen) dan wel

prostaat-verwijdering (mannen) via de buik.................. Ja 0 Nee 0 zo ja, in welk jaar?.

Baarmoeder-verwijdering via de schede (vrouwen) dan wel prostaat-verwijdering via de urinekanaal (mannen)............Ja 0 Nee 0 Zo ja, in welk jaar?..........................

Verzakkings-operatie (alleen vrouwen) ................... Ja o Nee o Zo ja, in welk jaar?......................... $\square \square \square \square \square$

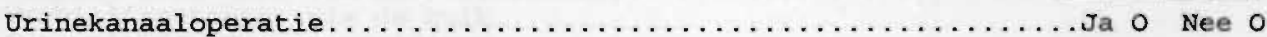
Zo ja, in welk jaar?........................

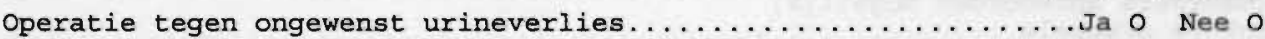
Zo ja, in welk jaar?...........................

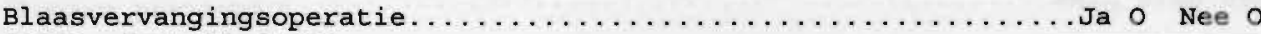
Zo ja, in welk jaar?.......................

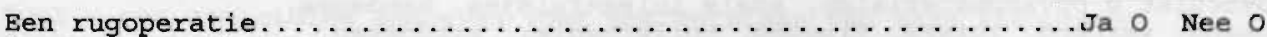
Zo ja, in welk jaar?.

Vraag 23 tot en met vraag 25 zijn alleen voor vrouwen

23. Hoeveel kinderen heeft u gebaard?

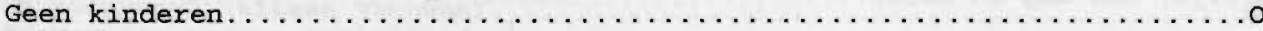

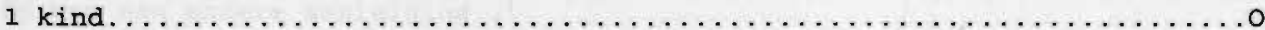

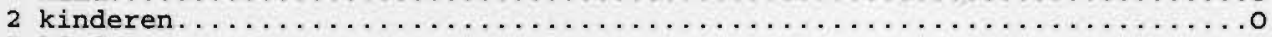

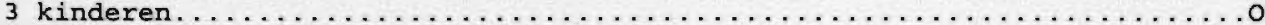

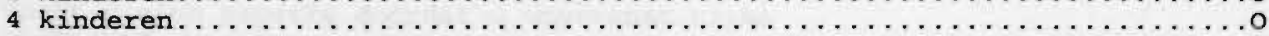

5 of meer dan 5 kinderen. . . . . . . . . . . . . . . . . . . . . . 
24. Zijn de bevallingen probleemloos verlopen? Ja $O$ Nee 0

Zo nee, wat is van toepassing? (meerdere antwoorden zijn mogelijk)

Eén of meerdere kinderen zijn met de tang of en vacuümkapje gehaald......

Eén of meerdere kinderen zijn via een keizersnede gehaald............

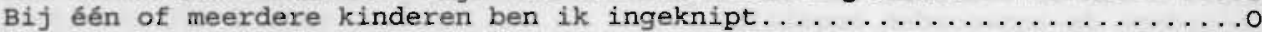

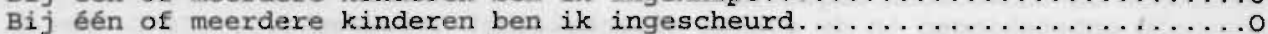

Bij één of meerdere kinderen was de bevalling langdurig en zwaar........

25. Op welke leeftijd bent $u$ in de overgang gekomen?.. Weet ik niet 0

Onderstaande vragen zijn weer voor iedereen

26. Gebruikt $u$ op dit moment plastabletten?. Ja $O$ Nee 0

27. Gebruikt $u$ nog andere medicijnen?...................... Ja o Nee o zo ja, wilt u die hieronder opschrijven?

De volgende vragen behoeven alleen ingevuld te worden indien u weleens onwillekeurig urine verlie日t.

28. Hoe vaak verliest $u$ ongewenst urine?

Minder dan 1 keer per maand. . . . . . . . . . . . . . . . . . . . . . .

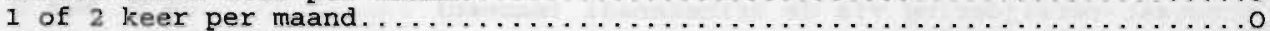

3 keer per maand. . . . . . . . . . . . . . . . . . . . . . . . . . .

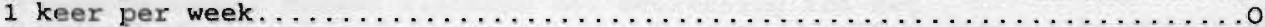

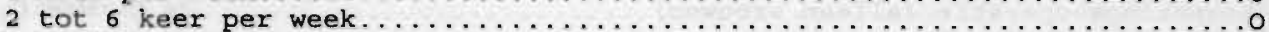

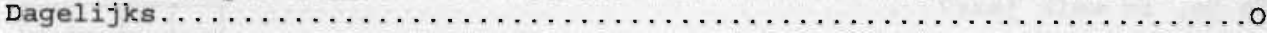

29. Hoe groot zijn de hoeveelheden die u per keer verliest?

(meerdere antwoorden mogelijk)

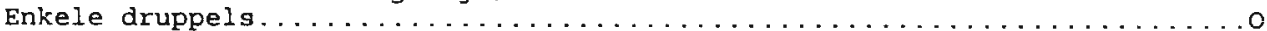

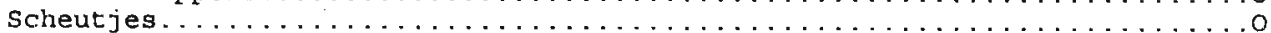

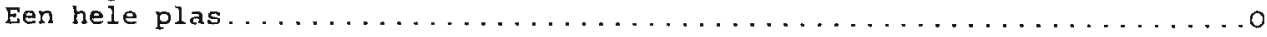

30. Gebruikt u opvangmaterialen, zoals inlegkruisjes, bandages, maand- verband, luiers, tissues, toiletpapier, zakdoeken, een catheter en dergelijke?..........................Ja o Nee o

wilt $u$ onderstrepen in bovengenoemde vraag wat u gebruikt?

Zo ja, wat is van toepassing?

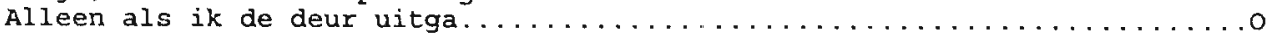

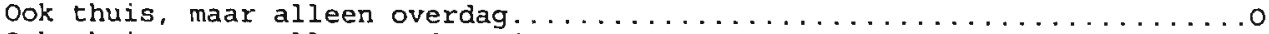

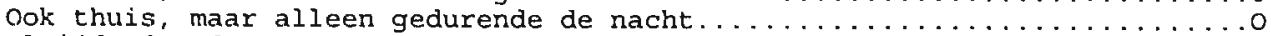

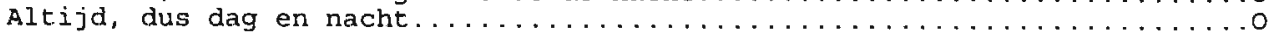


31. Hoeveel van dergelijk opvangmateriaal. gebruikt u gemiddeld per dag?

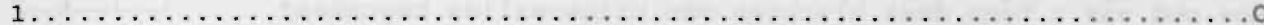

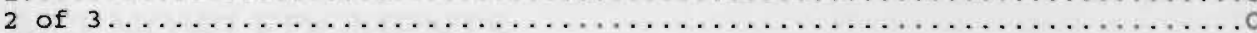

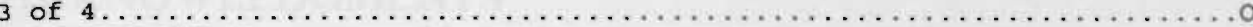

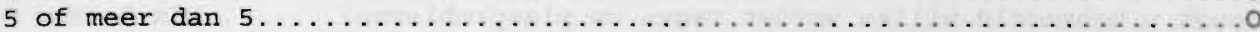

32. Verliest $u$ weleens urine terwijl u drang heeft?............. Ja 0 Nee 0

33. Verliest $u$ alleen's nachts urine, tijdens de slaap?......... Ja o Nee o

34. Loopt uw urine weleens af, zonder dat $u$ het voelt?.......... Ja 0 Nee 0

35. Verliest $u$ bij één of meer van de volgende situaties ongewild urine? (meerdere Ja-antwoorden mogelijk)

Tijdens hoesten of niezen.......................... Ja o Nee 0

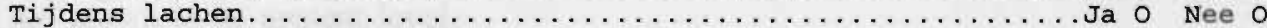

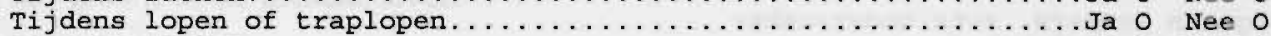

Tijdens tillen..................................... Ja o Nee o

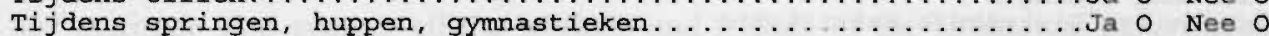

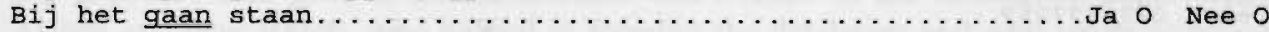

36. Bent $u$ weleens bij een dokter geweest voor uw plasproblemen?...Ja 0 Nee 0

zo ja, wat dit bij: (meerdere antwoorden mogelijk)

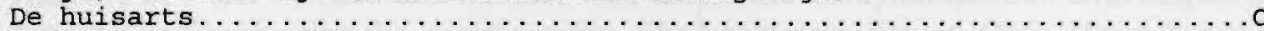

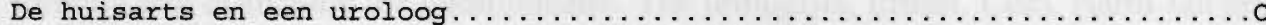

De huisarts en een gynaecoloog (vrouwenarts) (alleen vrouwen) ............

De huisarts, een uroloog en een gynaecoloog (vrouwenarts) (alleen vrouwen). O

37. Bent u behandeld?................................ Ja o Nee o

Zo ja, wat is van toepassing? (meerdere Ja-antwoorden mogelijk)

Fysiotherapie (bekkenbodemtraining) ........................ Ja Nee 0

Toilettraining (blaastraining) .......................... Ja o Nee 0

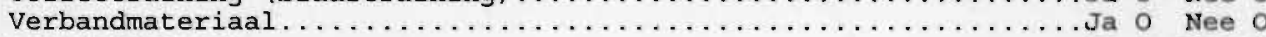

Baarmoederring.................................... Ja o Nee 0

Medicijnen.................................. Ja o Nee 0

Verblijfscatheter via het urinekanaal...................Ja $a$ Nee $D$

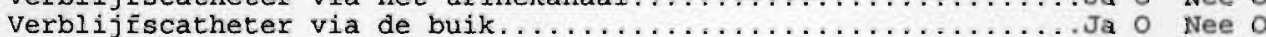

Intermitterend catheteriseren.......................... Ja Nee $D$

operatie......................................... Ja G Nee 0

38. Bent u na de behandeling droog geweest (gedurende een kortere of

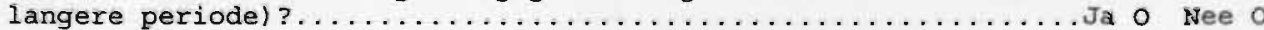

39. Kunt $u$ een aanleiding aangeven voor het ontstaan van deze klachten? Wilt $u$ aankruisen wat voor $u$ van toepassing is? (meerdere antwoorclen mogelijk)

Vele blaasontstekingen? . . . . . . . . . . . . . . . . . . . . . . .

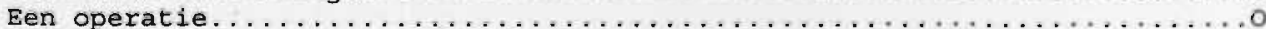

Een catheterisatie? (hierbij wordt er een slangetje in lu blaas gestopt)...0

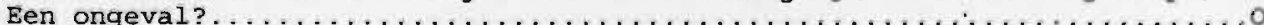

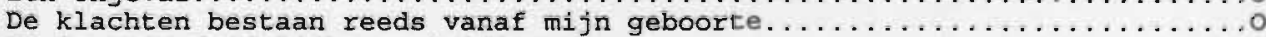

Er is geen duidelijke aanleiding . . . . . . . . . . . . . . . . . . . . .

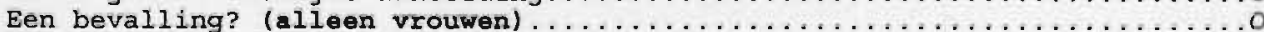

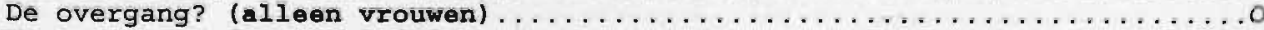

Er was een andere aanleiding . . . . . . . . . . . . . . . . . . . . . . .

40. Voelt $u$ zich beperkt doordat $u$ ongewenst urine

verliest?............................Weet ik niet o sa o Nee o 
41. Hoe oud was u toen deze klachten van urineverlies begonnen?..... $\square \square \square$

42. Zoudt $u$ behandeld willen worden tegen uw plasproblemen?......Ja 0 Nee 0

Deze latste vraag is weer voor iedereen

43. Wie heeft deze vragenlijst ingevuld?

Ik zelf alleen. . . . . . . . . . . . . . . . . . . . . . . . .

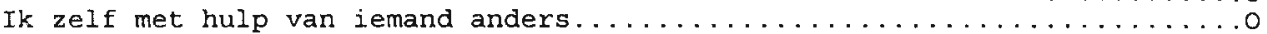

Onze hartelijke dank voor het invullen.

Ageeth Remmers, arts-onderzoeker

Afdeling Urologie

Academisch Ziekenhuis Maastricht

tel. : 043-877259 


\section{ACKNOWLEDGMENTS}

In the first place I would like to express my gratitude towards the patients and inhabitants who, probably for the umpteenth time, gave their cooperation. Without them, research would not have been possible.

Also, I would like to acknowledge Prof. dr. R.A. Janknegt en Dr. ir. E.S.C. van Waalwijk van Doorn. Dear professor, without your support and advice this thesis still had to be born. Dear Ernst, without your support, ideas and friendship, this thesis had not grown to its present level.

My gratitude also goes to all the workers and friends of the Urological department. Alfons and later Ralph, who helped in forming the databases and who wrote software programs for entering the data in a user-friendly way. John, who was my back-up. Jeanne, who did a lot of work regarding filling and analysing the databases for chapters 3,5 and 7. Theo and Sabine, who taught me urodynamics and who helped in forming and evaluating the questionnaire. The urologists, Ernest, Cees, Harm Jan and Victor for their support and education. And last but not least, the residents, research co-workers, nurses, secretaries and administrative workers for their friendship and support.

Also, a word of thank to all who made the questionnaire survey in homes for the elderly possible. You contributed to one of the most important parts of this thesis.

To pap, mam, Luciënne and Pieter: many thanks for your love, understanding and support. 


\section{CURRICULUM VITAE}

The author was born in Muntendam on July 22th 1961.

She finished atheneum B at the Sint Michiel Scholengemeenschap in Geleen (1980). In the same year she started at the Free University in Amsterdam with her medical degree, which she finished in February 1989. From July 1989 she worked at the Urology Department of the Maastricht University Hospital (head: Prof. dr. R.A. Janknegt), first as resident in research, till 1994, and later as a research co-worker. 

